\title{
Język hebrajski oraz jidysz w sztuce Haima Maora, izraelskiego artysty drugiego pokolenia*
}

Haim Maor (חיים מאור), urodzony w 1951 roku w Jaffie, jest jednym z pierwszych twórców wizualnych w Izraelu, którzy wprost podjęli temat Holokaustu i wprowadzili go w obszar rodzimej sceny artystycznej. W wielu realizacjach posługuje się on słowem lub tekstem, między innymi w językach jidysz oraz hebrajskim - i to na nich właśnie chciałbym skoncentrować uwagę. Wyrazy wchodzą w złożone relacje z motywami wizualnymi, z kolorami. W pracach Haima Maora, kompozycjach, które mogą kojarzyć się z poematami wizualnymi, układy typograficzne są równie ważne jak znaczenia słów. Użycie języków, tłumaczeń, rozbijanie wyrazów, zestawianie ich, wydobywanie podtekstów stało się - można powiedzieć - znakiem rozpoznawczym artysty.

Haim Maor prowadzi gry słowne, tworząc różnego rodzaju neologizmy, jak na przykład w pracy z 2011 roku pt. אמנביא / ArtistProphet ${ }^{1}$ (czyt. omanawi). Połączenie wyrazów „artysta” (אמן - czyt. oman) i „prorok” (נביא - czyt. nawi²)

* Artykuł powstał w związku z realizacją tematu pt. „Język hebrajski w sztuce artystów konceptualnych (i postkonceptualnych) w Izraelu", w ramach badań statutowych Wydziału Edukacji Artystycznej i Kuratorstwa Uniwersytetu Artystycznego w Poznaniu, finansowanych ze środków Ministerstwa Nauki i Szkolnictwa Wyższego na naukę w latach 2016-2018 jako projekt badawczy. Wykorzystałem w nim fragmenty pracy magisterskiej pt. Tekst i obraz w sztuce Haima Maora - artysty drugiego pokolenia ocalonych z Zagłady, napisanej pod kierunkiem prof. Piotra Muchowskiego w Katedrze Studiów Azjatyckich Uniwersytetu im. Adama Mickiewicza w Poznaniu i obronionej w $2014 \mathrm{r}$.

${ }^{1}$ Tytuły podaję w języku hebrajskim (w wersji oryginalnej) oraz w języku angielskim, w tłumaczeniu artysty.

2 Słowo "nawi” pochodzi najprawdopodobniej od akadyjskiego (babilońsko-asyryjskiego) rdzenia i oznacza „powołany” lub „wezwany” (przez Boga). Por. L. Trepp: Żydzi. Naród, historia, religia. Przeł. S. Lisiecka. Warszawa 2009, s. 240. 
jest - w kontekście postawy Haima Maora - niezwykle wymownym manifestem. Słowo אמנביא namalowane zostało na desce, umieszczone wewnątrz owalnej, przypominającej oko formy, z której rozchodzą się we wszystkich kierunkach promienie, co przywodzi na myśl słońce. Dzięki temu prostemu zabiegowi twórca pokazuje, że zdecydowanie odrzuca dominujące dziś modele bycia artystą, wybierając niemodną, staroświecką drogę artysty-proroka. Artysta-prorok to ktoś, kto - jak powiada Maor - „podąża ze swoją prawdą aż do końca, za co płaci wysoką cenę"3. Ktoś, kto - jak przekonywał Gershom Scholem, „słyszy wyraźnie posłanie i możliwe, że widzi także równie wyraźną wizję, która ani w swoim odbiorze, ani w jego pamięci nie ma cech nieostrych"4.

W bardzo podobnej konwencji Maor zrealizował pracę datowaną na lata 1991-2007, zatytułowaną ראייה/יראה ( Reiya/Yira’a (Vayare/Vayera) (czyt. reija, czyli „widzenie” / czyt. jira’a, czyli „strach”, „przerażenie” / czyt. wajira’a, czyli „bojaźń, „osoba bogobojna”). Słowo וירא zostało wykaligrafowane, wraz ze znakami diakrytycznymi (tzw. „niqqud”, czyli ניקוד), na prostokątnej desce, której krawędzie pomalowano kolorem czarnym, co tworzy rodzaj ramy przypominającej nekrolog. Wyraz ten, nawiązujący do biblijnej historii Abrahama z Księgi Rodzaju, zajmuje centralne miejsce na płaszczyźnie obrazu. Znajduje się on (podobnie jak אמנביא) wewnątrz formy przypominającej oko, którą tworzą dekoracje charakterystyczne dla tzw. inicjału. Można to odczytać jako nawiązanie do średniowiecznych ksiąg. „Samowystarczalna sfera ikon, wizerunków znanych z chrześcijaństwa i pogaństwa, była Żydom wzbroniona. Biblijny zakaz sporządzania obrazów niekiedy uchylano, ale wyłącznie w takich wypadkach, gdy obrazy służyły - podkreślali Amos Oz oraz Fania Oz-Salzberger - słowom, ilustrowały ich znaczenie, stanowiły lustro, w którym przeglądała się opowieść" ’. Joram Bronowski podkreślał, że „forma wewnętrzna” języka Biblii „w niczym nie przypomina hebrajszczyzny izraelskiej”. „Paradoksalnie - pisał Bronowski forma zewnętrzna (tj. same słowa) obu języków jest dość zbliżona, toteż izraelski czytelnik nieustannie ulega złudzeniu: zdaje mu się, że może zrozumieć, choć w rzeczywistości nie rozumie"6. Podobnie problem ten postrzega Yakov M. Rabkin: „Język hebrajski, który teoretycznie powinien zapewnić Izraelczykom dostęp do klasyki judaizmu, stawał się niekiedy barierą. Odkryli oni, że ich język nie dorasta do potrzeb, że musiałby być wzbogacony o inne słowa i inne idee. To, co okazało się najtrudniejsze, to nauka całego słownictwa judaistycznego, które zostało bądź całkowicie zarzucone, bądź to przekształcone przez wczesnych syjo-

${ }^{3}$ R. Jакuвоwicz: Midrasz wizualny albo trzecie znaczenie. Z Haimem Maorem rozmawia Rafał Jakubowicz. Przeł. R. Jакuвоwicz. „Midrasz. Pismo Żydowskie” 2014, nr 6 (182), listopad/ grudzień, s. 9.

${ }^{4}$ G. Scholem: Kabała i jej symbolika. Przeł. R. Wojna kowski. Warszawa 2014, s. 19.

${ }^{5}$ A. Oz, F. Oz-Salzberger: Żydzi i słowa. Przeł. P. Paziński. Warszawa 2014, s. 54.

${ }^{6}$ J. Bronowski: Jakie sq widoki Biblii. Przeł. L. KwiAtкowski. „Literatura na Świecie” 2004, nr 11-12 (400-401), s. 420. 
nistów. Współczesny hebrajski, zaprojektowany do użytku dnia codziennego, ze zmodyfikowanymi lub zaktualizowanymi znaczeniami judaistycznymi, daje dziś Izraelczykowi, który otwiera Torę, ograniczone możliwości”" Jak słusznie zwrócił uwagę Piotr Paziński, „każde słowo niesie ze sobą wieki historii, masę skojarzeń i sensów, począwszy od Biblii, poprzez gigantyczny ocean literatury rabinicznej, na języku współczesnym skończywszy" ham Abulafia, trzynastowieczny sefardyjski kabalista, autor między innymi Sefer ha-'oth (Księgi znaku), twierdził, że hebrajski w swojej utajonej strukturze lingwistycznej zawiera wszystkie języki świata. „Gdy kabaliści - pisał Charles Mopsik - rozprawiają o języku hebrajskim, w istocie rozprawiają o języku w ogóle, gdyż język hebrajski jest wezwaniem do istnienia i świętą nazwą wszystkiego, co zostało stworzone"'. Szczególny nacisk Abulafia kładł na pismo - 22 litery alfabetu hebrajskiego. „Każda litera, jeśli tylko mistyk w sposób właściwy się w nią zagłębi, stanowi - jak to ujął Gershom Scholem - świat dla siebie"10.

Haim Maor czerpie zarówno z tradycji malarstwa europejskiego, jak i doświadczeń konceptualizmu, minimal artu, body artu, opartu, poezji wizualnej oraz konkretnej. Jego postawa wyraża się nie tyle w rozpoznawalnym stylu, ile raczej $\mathrm{w}$ konsekwentnym poruszaniu się $\mathrm{w}$ obszarze pamięci, $\mathrm{w}$ obsesyjnie powracających motywach wizualnych, w ciągle przywoływanych wydarzeniach z przeszłości, $w$ rodzinnych historiach oraz $w$ licznych odniesieniach do autobiografii. Maor, próbując zrekonstruować i zrozumieć to, czego doświadczyli jego bliscy podczas Zagłady, zdany jest na strzępy zasłyszanych przed laty, w domu rodziców, rozmów, w których ożywały skrzętnie przed nim ukrywane bolesne wspomnienia. On sam doświadczył Holokaustu pośrednio, podobnie jak wielu jego rówieśników będących świadkami niepokoju domowników. Ocaleni z Zagłady cierpieli, jak pisał Tom Segev, „z powodu lęków i koszmarów, zamykali się w sobie, zdarzały się im ataki depresji, gniewu i apatii; mieli trudności z koncentracją i nawiązywaniem kontaktów z innymi; podejrzliwi wobec obcych, dręczeni wszechogarniającym niepokojem co do osobistego, materialnego i zawodowego bezpieczeństwa, czuli wielki strach i mieli wielkie aspiracje wobec dzieci. Wielu wychowywało je w poczuciu, że ich własne życie jest nic nie warte, że jego jedynym celem jest zapewnienie dobra, dobrobytu i przyszłości potomstwu. Zmuszali dzieci do niesienia ciężaru wspomnień, nadając im imiona krewnych, którzy zginęli w Zagładzie. Liczni - być może większość - nie mogli i nie chcieli

7 Y.M. Rabkin: W imię Tory. Żydzi przeciwko syjonizmowi. Przeł. Ł. BRzezıński. Warszawa 2007, s. 83.

${ }^{8}$ Cyt. za: A. Pluszka: Trzy klocki w puzzlach. Rozmowa z Piotrem Pazińskim. Dostępne w Internecie: http://www.dwutygodnik.com/artykul/6855-trzy-klocki-w-puzzlach.html [data dostępu: 14.08.2018].

9 Ch. Mopsik: Kabała. Przeł. A. Szymanowski. Warszawa 2001, s. 119.

${ }^{10}$ G. Scholem: Mistycyzm żydowski i jego główne kierunki. Przeł. I. Kania. Warszawa 2007, s. 152. 
opowiadać dzieciom o tym, czego doświadczyli, a dzieci nie śmiały pytać, jak gdyby odpowiedź była straszliwym, groźnym sekretem rodzinnym. Lęki wyniesione z Zagłady mogły nagle uwidocznić się w codziennym życiu, obudzone zwykłymi zdarzeniami w domu, w pracy czy usłyszanymi w wiadomościach. Choroba, utrata pracy czy incydent graniczny - wszystko to przenosiło ich "tam«. Przeszłość ożywała nieraz jeszcze wiele lat po wojnie"11.

Haim Maor, który dorastał w otaczającej Holokaust ciszy, stara się wyrazić to, czego nie udało się wypowiedzieć jego bliskim, ponieważ nie mogli lub nie chcieli mówić. „Pod koniec 1949 roku niemal co trzeci mieszkaniec Izraela spośród około trzystu pięćdziesięciu tysięcy osób był ocalonym z Zagłady. Wielu z nich było tak poważnie psychicznie i fizycznie zniszczonych, że z trudem udawało im się włączyć w wyczerpujące codzienne życie społeczności żydowsko-palestyńskiej. Niektórzy całkowicie wyparli lata Zagłady ze swojej tożsamości. Inni wszystkie nowe doświadczenia postrzegali - pisał Göran Rosenberg - poprzez pryzmat stale tkwiących pod powiekami obrazów z każdej sekundy czasu upokarzania i unicestwienia” ${ }^{2}$. Inaczej mówiąc: „W pierwszych latach istnienia państwa żydowskiego jego splecenie z Zagładą nabrało niemal mitycznego charakteru"13. Sztuka jest dla Maora środkiem przepracowywania traum i rodzinnych tajemnic, a także - pośrednio - narzędziem krytyki oraz demistyfikacji ideologii funkcjonujących w izraelskim społeczeństwie. Jest również rodzajem autoterapii (badania nad poholokaustową traumą obejmują nie tylko ocalałych z Zagłady, ale też ich rodziny, łącznie z dziećmi, które urodziły się już po wojnie). Dlatego pisząc o sztuce tego artysty, musimy nieustannie sięgać do autokomentarza. „Badania nad syndromem poobozowym podjęto zaś długo, bo kilkanaście lat, po wojnie. Byli więźniowie - świadkowie Zagłady - nie od razu więc zostali wysłuchani. Z jednej strony polityczna dyrektywa kontrolowanego ujawnienia traumy, a z drugiej - brak badań psychiatrycznych nad skutkami pobytu w obozie sprzyjały - pisała Joanna Krakowska - pielęgnowaniu milczenia jako przejawu syndromu posttraumatycznego lub reprodukowania podniosłych i sentymentalnych narracji jako formy radzenia sobie z nim"14.

Rodzina Haima Maora pochodzi z Łańcuta i Płońska. W 1886 roku w Płońsku urodził się również Dawid Grün, znany później jako Dawid Ben-Gurion. Rodziny Moshkovitzów i Grünów mieszkały w tym samym domu przy ul. Płockiej 10, który należał do rodziny Finkelsteinów ${ }^{15}$, o czym Haim Maor do-

${ }^{11}$ T. Segev: Siódmy milion. Izrael - piętno Zagłady. Przeł. B. Gadomska. Warszawa 2012, s. 152.

${ }^{12}$ G. Rosenberg: Kraj utracony. Moja historia Izraela. Przeł. M. Haykowska. Wołowiec 2011, s. $270-271$.

${ }_{13}$ Tamże, s. 275.

${ }^{14}$ J. Krakowska: Obóz. W: Ślady Holokaustu w imaginarium kultury polskiej. Red. J. Kowalska-Leder, P. Dobrosielski, I. Kurz, M. Szpakowska. Warszawa 2017, s. 295.

${ }^{15}$ Rodzina Haima Maora mieszkała w tym samym domu, w którym mieszkała rodzina Dawida Ben-Guriona - rodzina Grünów. Por. Neighbors [„Several Other Jewish Residents"]. In: 
wiedział się od kolegi z pracy Haima Finkelsteina, dziekana Wydziału Sztuki Ben-Gurion University of the Negev, podczas towarzyskiej rozmowy dotyczącej planowanego wyjazdu do Polski. Do tej historii odnosi się obraz z 2010 roku, zatytułowany דו דוד (czyt. du Dawid, czyli „dwóch Dawidów”). Widnieje na nim herb Płońska wpisany w formę nawiązującą do tarczy Dawida. Niżej przedstawione zostały kontury profili twarzy Dawida Moshkovitza - ojca Haima, i Dawida Ben-Guriona - „ojca” Państwa Izrael. Rodzina Moshkovitzów mieszkała na pierwszym piętrze płońskiej kamienicy Finkelsteinów, rodzina Grünów na drugim. W tych dwóch historiach splatają się pogmatwane losy polskich Żydów. Dawid Grün wcześnie, ponieważ już w 1906 roku, w czasie drugiej aliji, wyemigrował do Palestyny, by wiele lat później, w 1948 roku, już jako Dawid Ben-Gurion, zostać pierwszym premierem Izraela. Dawid Moshkovitz przeszedł przez Auschwitz, a do Izraela trafił jako jeden z ocalałych z Holokaustu w 1949 roku, podczas masowej, wielkiej aliji zwanej też „oberwaniem chmury”16.

Pod obrazem znajduje się niebieska tablica $\mathrm{z}$ napisem w jidysz: איך בין דובטשה (czyt. ich bin Duwcze, czyli „jestem Dawid”) גרין I מושקוביץ דיק (czyt. Grün | Moshkovitz) פון פלונסק (czyt. von Plonsk, czyli „z Płońska”).

Dawida Grüna, który wcześnie, bo w wieku jedenastu lat, stracił matkę, nazywano w domu „Duwcze”. Hebrajskiego uczył go dziadek. Razem z kolegami, Szlomo Fuchsem i Szlomo Zamachem, młody Duwcze utworzył organizację Ezra, która obrała sobie za cel krzewienie wśród rówieśników w Płońsku, sztetle, w którym - podobnie jak w innych miastach z tzw. strefy osiedlenia większość stanowili Żydzi, wiedzy o hebrajszczyźnie. „Decyzja trzech chłopców z Płońska, którzy postanowili mówić między sobą po hebrajsku i uczyć tego języka swoje rodziny, była więc prawdziwym manifestem kulturalnym i politycznym. Okazało się, że odnieśli taki sukces, iż mówienie po hebrajsku - pisała Anita Shapira - stało się znakiem rozpoznawczym młodych syjonistów z tego miasta"17. Mówiony hebrajski był wówczas rzadkością, zresztą nie tylko w Polsce, ale również w Palestynie. Zmieniło się to dopiero wówczas, gdy pojawiło się pierwsze pokolenie absolwentów Gimnazjum Herzlija w Tel Awiwie, założonego w $1905 \mathrm{roku}^{18}$.

Haim Maor. They are Me. The Open Museum, Tefen and Omer Industrial Parks, 2011, s. 212-211. Artysta wspomina o tym również w wywiadzie pt. Midrasz wizualny..., s. 5-6. Opieram się tutaj na relacjach Haima Maora oraz Haima Finkelsteina. Anita Shapira podaje, że Grünowie posiadali dwie kamienice, z których jedną wynajmowali, a w drugiej - przy ul. Koziej - mieszkali. Por. A. Shapira: Ben Gurion. Twórca wspótczesnego Izraela. Przeł. H. Jankowska. Warszawa 2018, s. 18-19. Chodzi mi rzecz jasna o kamienicę na płońskim rynku, na której znajduje się płyta pamiątkowa (obecny adres: pl. 15 Sierpnia 21A).

${ }^{16}$ Por. A. Shapira: Historia Izraela. Przeł. A.D. Kamińska. Warszawa 2018, s. 263.

17 A. Shapira: Ben Gurion..., s. 23.

${ }^{18}$ Por. tamże, s. 22. 
„Nie możemy porozumiewać się między sobą po hebrajsku. Kto bowiem $\mathrm{z}$ nas zna na tyle hebrajski, aby kupić $\mathrm{w}$ tym języku na przykład bilet kolejowy? Nie da się. Jednak rozwiązanie jest bardzo proste. Każdy - proponował Teodor Herzl w opublikowanym w 1896 roku Państwie Żydowskim... - zachowa język, będący ukochaną ojczyzną jego myśli. Dostatecznym przykładem takiego językowego federalizmu może być Szwajcaria. Pozostaniemy zatem po tamtej stronie tacy sami jak teraz, podobnie jak nigdy nie przestaniemy z nostalgią wspominać rodzinnych stron, które porzuciliśmy"19. Teodor Herzl, choć zakładał, że językiem narodowym stanie się - niejako w naturalny sposób - język, który będzie w nowym państwie najczęściej używany, nie ukrywał negatywnego stosunku do żydowskich języków diaspory. „Odwykniemy - pisał - od skarłowaciałych i wytartych żargonów - tych języków getta - którymi posługujemy się teraz. Były to języki na kształt więziennych grypsów"20. Język żydowski traktowany był przez syjonistów jak „popsuty niemiecki” i odrzucany jako mogący pretendować do miana języka narodowego. Dawid Grün oraz Dawid Moshkovitz mówili w jidysz. Dawidowi Ben-Gurionowi (Grün przyjął nazwisko przywódcy wielkiego buntu przeciw Rzymowi ${ }^{21}$ ) zależało, żeby językiem urzędowym Izraela był hebrajski, a nie jidysz, ladino czy arabski. Zatem kontekstem, w którym należy czytać tę pracę Maora, jest pogardliwy wręcz stosunek Ben-Guriona do języka oraz kultury jidysz. Odrodzenie kultury żydowskiej i języka hebrajskiego stanowiło trzon syjonistycznego i socjalistycznego światopoglądu Ben-Guriona. „Podczas gdy żydowski robotnik w diasporze, żyjąc w duchowej nędzy, odwrócił się od wszystkich skarbów kultury, które jego naród stworzył w ciągu wieków, a zamiast nich swoim intelektualnym ideałem uczynił jidyszyzm, nowy hebrajski robotnik w Erec Israel stał się dziedzicem, prawdziwym właścicielem kulturalnych zasobów swego narodu. A głównym z nich jest ten, który - podkreślał Ben-Gurion - zawiera w sobie skarby - język"22. Podobnego zdania byli jego partyjni towarzysze, między innymi Berl Katznelson. „Poczynając od prób zainicjowanych już wcześniej w Rosji Carskiej, a mających na celu wyrażenie w nowoczesnym języku treści Biblii i Psalmów, językoznawcy syjonistyczni postanowili utworzyć nowy język: słownictwo zaczerpnięto z ksiąg biblijnych, natomiast pisownię z języków aramejskiego i asyryjskiego (tzn. z Miszny, a nie hebrajską), w składni zaś dominowała składnia jidysz i słowiańska (absolutnie nie biblijna). Ten język jest - pisał Shlomo Sand - obecnie niewłaściwie nazywany hebrajskim (osobiście czuję się przymuszony do używania tej błędnej nazwy) i uważam, że o wiele trafniej byłoby nazywać go, idąc tropem awan-

19 T. Herzl: Państwo Żydowskie. Próba nowoczesnego rozwiązania kwestii żydowskiej. Przeł. J. Surzyn. Kraków 2006, s. 132.

20 Tamże.

${ }^{21}$ A. Shapira: Ben Gurion..., s. 33.

${ }^{22}$ Cyt. za: Ben Gurion. Żywot polityczny. Z Szimonem Peresem rozmawia David Landau. Przeł. H. Jankowska. Warszawa 2013, s. 59. 
gardowych lingwistów - izraelskim. Nowy język rozwinął się na długo przed utworzeniem państwa Izrael i szybko stał się językiem używanym systematycznie przez wspólnotę syjonistyczną osiedloną w Palestynie. Stał się również językiem - mówionym i pisanym - dzieci tych pionierów, które utworzą elitę kulturalną, wojskową i polityczną początków państwa Izrael. Ci sabra (osadnicy) stanowczo i energicznie sprzeciwiali się kulturze jidysz, zachęcani do tego przez przywódców wspólnoty imigrantów. Dawid Ben-Gurion zabronił - zwrócił uwagę Sand - używania języka Żydów z Europy Wschodniej na kongresach jego partii socjalistycznej; jedno posiedzenie przeszło do historii: kiedy była partyzantka z Wilna wspominała w 1944 r., na zebraniu związku żydowskich robotników, Zagładę w swojej ojczyźnie, przywódca-założyciel przerwał jej wypowiedź i ostro potępił używanie tego języka »dziwacznego i krzykliwego«, jak to określił. Na uniwersytecie hebrajskim w Jerozolimie, założonym w 1925 r., nie było katedry języka jidysz, toteż studenci pragnący zapoznać się z tą zniszczoną kulturą, musieli czekać aż do 1951 roku. W 1949 r. tuż po utworzeniu państwa Izrael, kiedy nastąpił masowy napływ Żydów mówiących jidysz, ocalonych z Zagłady, została przegłosowana specjalna ustawa zabraniająca obywatelom izraelskim wystawiania sztuk teatralnych w języku imigrantów (jedynie zaproszeni artyści z zagranicy mieli prawo występować w języku »wygnania«, w okresie nieprzekraczającym sześciu tygodni). Dopiero na początku lat 70 . $\mathrm{XX}$ w., kiedy nowa kultura autochtonów w Izraelu zyskała pełnię bezpieczeństwa, można było zauważyć złagodzenie kursu wobec tego starego pogardzanego języka. Dyskredytacja i arogancja w stosunku do jidysz dotknęła również kulturę i język innych wspólnot imigranckich"23. Göran Rosenberg przypominał, że wyrazem sprzeciwu wobec jidysz w latach 50 . był wydawany przez szkoły zakaz czytania wierszy oraz śpiewania pieśni w języku diaspory ${ }^{24}$. Wysiłek Eliezera ben Jehudy, który pracował nad modernizacją języka hebrajskiego, polegającą między innymi na ujednoliceniu i uproszczeniu zasad gramatycznych, tworzeniu nowych słów, wprowadzeniu „zachodnich” zasad interpunkcji, okazał się owocny. „Ben Jehuda zainicjował modernizację języka hebrajskiego i jego zdumiewający renesans. Sukces ten wyjaśnić można wręcz rytualną rolą, jaką odgrywał hebrajski we wczesnych latach pionierskich. Stał się dla ludzi - jak to określił Rosenberg - kulturową kąpielą oczyszczającą, mistyczną obietnicą, że nic już nie będzie po staremu, przypieczętował wreszcie dotarcie do kraju obiecanego” ${ }^{25}$. Syjoniści wygrali walkę o język hebrajski. „Wskrzeszenie języka hebrajskiego i jego przemiana w ciągu trzech, czterech pokoleń ze śpiącej królewny w mowę codzienną ponad dziesięciu milionów ludzi jest nie mniej waż-

${ }^{23}$ Sh. SAnd: Dlaczego przestałem być Żydem. Spojrzenie Izraelczyka. Przeł. I. BadowsKa. Warszawa 2014, s. 63-64.

${ }^{24}$ Por. G. Rosenberg: Kraj utracony..., s. 281.

${ }^{25}$ Tamże, s. 54. 
nym wydarzeniem duchowym w dziejach narodu żydowskiego niż - twierdzi Amos $\mathrm{Oz}$ - powstanie Talmudu"26.

Jednak porzucenie języka diaspory oznaczało również radykalne odcięcie od europejskiej historii i kultury. „Zwycięstwo języka hebrajskiego nad jidysz nie było zwycięstwem jednego języka nad drugim, lecz raczej - stwierdził Yakov M. Rabkin - zwycięstwem ideologii odrzucającej wygnanie i stawiającej sobie za cel utworzenie "Nowego Człowieka Hebrajskiego " 27 . Pod koniec lat 40. i na początku lat 50. działacz Bundu Isachar (Oskar) Artuski zwracał uwagę, że hebrajski nie wypełniał miejsca po zwalczanym języku żydowskim. Walka z jidysz osłabiała, w przekonaniu Artuskiego, naród żydowski, ponieważ to właśnie żywy język jidysz stanowił najważniejszy pomost kulturowy między diasporą a Izraelem. Bund konsekwentnie, acz bezskutecznie, domagał się, by języka żydowskiego nauczano we wszystkich placówkach oświatowych Izraela i żeby uzyskał on wszystkie prawa w życiu publicznym, podczas gdy partie syjonistyczne uczestniczyły w jego dyskryminacji ${ }^{28}$. „Syjonizm usiłował przetopić ludzi z różnych diaspor w jedno ciało z kolektywną tożsamością, wyrażającą się w kulturze narodowej, symbolach i rytuałach oraz - spostrzegła Anita Shapira - wspólnym etosie"29. Żydzi z całego świata emigrujący do Palestyny, a potem Izraela, pochodzący z różnych kultur, poddawani byli za pomocą systemu edukacji oraz obowiązkowej służby wojskowej - które tworzyły, jak to ujął Shlomo Sand, „potężny tygiel kształtujący tożsamość i swoistą kulturę" ${ }^{30}$ - integracyjnym procesom zmierzającym do zjednoczenia imigrantów, dzięki czemu mogli stać się nowymi podmiotami: Izraelczykami i zarazem budowniczymi nowego kraju. „Każdy, kto przed zwerbowaniem do armii rozmawiał ze swoimi rodzicami w obcym, pogardzanym języku (jidysz lub arabskim), po dwóch czy trzech latach spędzonych w CaHaL-u (Siły Obronne Izraela), stawał się nie tylko dobrym żołnierzem, ale również obywatelem bardziej izraelskim. Zazwyczaj zaczynał pisał Sand - uczyć swoich rodziców języka państwowego i tym samym wsączać im poczucie wstydu wobec ich dawnej kultury, pozbawionej wojskowego wigoru i dumy narodowej" ${ }^{31}$. Obecnie pośród dzieci oraz zwłaszcza wnuków imigrantów, zmagających się z poczuciem wykorzenienia, możemy zaobserwować wzmożone zainteresowanie kulturą diaspory, swoisty jej renesans. Także krytyka syjonistycznego projektu skłania do podjęcia próby odnalezienia utraconej kultury rodziców i dziadków. Zresztą nawet sam Ben-Gurion im był starszy, tym

${ }^{26}$ A. Oz: Do fanatyków. Trzy refleksje. Przeł. L. Kwiatkowski. Poznań 2018, s. 95.

${ }^{27}$ Y.M. Rabkin: $W$ imię Tory..., s. 78.

${ }^{28}$ Por. A. Grabski: Lewica przeciwko Izraelowi. Studia o żydowskim lewicowym antysyjonizmie. Warszawa 2008, s. 102-106.

${ }^{29}$ A. Shapira: Historia Izraela..., s. 456.

${ }^{30}$ Sh. SAnd: Dlaczego przestałem być Żydem..., s. 76.

${ }^{31}$ Tamże. 
mocniejszą więź czuł z Płońskiem, miastem, które stało się dla niego metaforą tragedii Żydów podczas Holokaustu ${ }^{32}$.

Rodzice Haima Maora spotkali się na pokładzie statku, którym płynęli uchodźcy z Europy, ocalali z Zagłady. Pobrali się w Jafie. Zamieszkali w Holonie, założyli dom w opuszczonej arabskiej ruinie. Ich syn otrzymał imiona po dziadku zamordowanym w 1942 roku w Auschwitz-Birkenau: Haim Benjamin Moshkovitz, które - już jako dorosły - zhebraizował (חיים מאור znaczy, życie ze światła”). „Ludzie zastępują - pisał Ari Shavit - jedne imiona innymi, jeden język innym językiem, jedną tożsamość inną tożsamością. Aby przetrwać, pozbawiają się przeszłości. Aby funkcjonować, stają się jednowymiarowi. Zmieniają się w ludzi czynu o sztywnych i zniekształconych osobowościach, o płytkich duszach. Pozwalając na to, aby kształtowała ich nowa, syntetyczna kultura pozbawiona tradycji i odcieni, tracą skarby kultury żydowskiej”33. Doświadczenie Haima Maora jest charakterystyczne dla tzw. drugiego pokolenia, czyli pokolenia potomków ofiar Zagłady, które dorastało w cieniu traum będących udziałem bliskich, które pragnęło skonfrontować się - zazwyczaj bezskutecznie - z przeszłością rodziny, a więc pośrednio z bolesną europejską historią, i które w końcu wybierało życie oraz wiarę $\mathrm{w}$ przyszłość, co symbolizowała właśnie zmiana nazwiska. Warto przypomnieć, że Ben-Gurion w kulminacyjnym momencie wojny o niepodległość wydał rozkaz, aby oficerowie oraz urzędnicy hebraizowali nazwiska. „Swoich współpracowników też nieustannie o to prosił, ustępował jedynie - zwróciła uwagę Anita Shapira - wtedy, gdy ktoś wykazał, że jest jedyną osobą z rodziny ocalałą z Holokaustu”34. Za powszechną "hebraizacją" nazwisk kryły się jednak rozmaite motywacje. „W pierwszych latach Państwa Izraela kult świętej trójcy »Księga-Lud-Ziemia« został rozwinięty przez elity intelektualne i Biblia stała się - pisał Shlomo Sand - centralną ikoną w tworzeniu narodowego świata wyobrażeń. Urzędnicy musieli pozmieniać imiona na brzmiące bardziej biblijnie, a reszta społeczeństwa, która próbowała w miarę możliwości identyfikować się i zbliżać do bardziej ugruntowanych elit, uczyniła to samo, dobrowolnie i z entuzjazmem. "Diasporyczne« nazwiska rodziców zostały na zawsze wymazane, a dzieci przyjęły rzadkie imiona wspaniałych i chwalebnych bohaterów biblijnych" ${ }^{35}$. Był jeszcze jeden powód powszechnej „hebraizacji” nazwisk - przydawała ona poczucia siły i dumy. „Dawne nazwiska rodowe kojarzyły się z Żydami słabymi, prowadzonymi na śmierć czy do obozów, jak bydło, inne przypominały tych, którzy służalczo naśladowali kulturę muzułmańską. W Izraelu należało być - pisał Shlomo Sand - nowym człowie-

32 Por. A. Shapira: Ben Gurion..., s. 228.

33 A. Shavit: Moja Ziemia Obiecana. Triumf i tragedia Izraela. Przeł. B. Gutowska-Nowak. Kraków 2014, s. 187.

${ }^{34}$ A. Shapira: Ben Gurion..., s. 196.

${ }^{35}$ Sh. Sand: Kiedy i jak wynaleziono naród żydowski. Przeł. H. Zвonikowska-Bernatowicz. Warszawa 2014, s. 160. 
kiem, Hebrajczykiem, umięśnionym, pełnym wigoru, zarówno fizycznego, jak i duchowego"36.

Haim Maor dorastał w domu, w którym nie posługiwano się poprawnie żadnym językiem. Jego rodzice nie mówili płynnie po hebrajsku. W domu używali jidysz. „Chociaż jiszuw został centrum kultury hebrajskiej w latach dwudziestych, nie zapewniło to dominacji kulturowej hebrajskiego jako języka mówionego. Każda fala imigracji przynosiła ze sobą ojczyste języki imigrantów. Podstawowym językiem żydowskim był jidysz, ukochany język ojczysty - zwróciła uwagę na ten swoisty paradoks Shapira - wszystkich propagatorów hebrajskiego" ${ }^{37}$. Z kolei ze sobą rodzice Maora rozmawiali po polsku, zwłaszcza wówczas, gdy bardzo im zależało, żeby syn czegoś nie rozumiał. Artysta do dziś pamięta wiele usłyszanych w dzieciństwie polskich słów. Inne języki, jak rosyjski i czeski, jego rodzice znali tylko pobieżnie. Maor dorastał więc w domu, w którym mieszało się różne dialekty, kaleczyło się języki ${ }^{38}$. Stąd chyba tak duże wyczulenie na znaczenia, jakie kryją się w słowach, w grach i lapsusach językowych oraz w formie ich wizualnego zapisu (w sztuce Maora ważny jest zarówno materiał, na którym pojawia się dany wyraz, jak również wybór odpowiedniej czcionki). I stąd chyba też próby tworzenia - śladem Ben Jehudy - nowych słów dla desygnatów nieposiadających nazwy w języku hebrajskim.

Choć Haim Maor w dzieciństwie rozumiał jidysz i mówił w jidysz, dziś już tym językiem się nie posługuje, zresztą podobnie jak większość Izraelczyków z jego pokolenia. Jak zwrócił uwagę Shlomo Sand, „na początku lat 70. XX w. sporo było takich, którzy nie ośmielali się przyznać, że mówią żałosnym językiem "wygnania «" 39 . Kultura jidysz została pogrzebana wraz z europejskimi Żydami. Choć we współczesnym Izraelu jidysz to prawie martwy język, będący głównie przedmiotem dociekań językoznawców, z roku na rok przybywa hobbystów zainteresowanych kulturą diaspory. „Bogata kultura jidysz to obecnie kultura wygasła. Owszem, są studenci, którzy uczęszczają na kursy nauki języka Żydów z Europy Wschodniej, ale nie rozmawiają i nie tworzą w tym języku. Nauka i związki z kulturą jidysz mogą - pisał Shlomo Sand - rozgrzać serca odczuwających nostalgię, ale nie mogą tworzyć osobowości i sytuacji znanych nam z pomników literatury pozostawionych m.in. przez Szolema Alejchema czy Isaaca Bashevisa Singera (to nie przypadek, że ci dwaj giganci literatury jidysz zakończyli swoje życie w Ameryce Północnej, a nie na Bliskim Wschodzie)"40. Język jidysz nazywany jest potocznie מאמעע-לשון (czyt. mame-luszen, czyli dosłownie "język matki”), w odróżnieniu od języka hebrajskiego, określanego jako לשון־קודש (czyt. laszon-kodesz, czyli „język święty”). „W wymiarze świętym, kodesz, he-

\footnotetext{
36 Sh. SAnd: Dlaczego przestałem być Żydem..., s. 74-75.

${ }^{37}$ A. Shapira: Historia Izraela..., s. 176.

${ }^{38}$ Por. R. Jакuвowicz: Midrasz wizualny..., s. 8-9.

${ }^{39}$ Sh. SAnd: Dlaczego przestałem być Żydem..., s. 59.

${ }^{40}$ Tamże, s. 61.
} 
brajski pozostawał podstawowym językiem Żydów. Ale nie umarł całkiem także w sferze świeckiej, chol, jako język dnia codziennego" - przekonują Amos Oz i Fania Oz-Salzberger ${ }^{41}$. Hebrajskie słowa funkcjonowały między innymi właśnie w jidysz. „W końcu debata jidysz-hebrajski wygasła po unicestwieniu milionów Żydów - mówiących w jidysz - w Europie Wschodniej. W ZSSR - pisała Anita Shapira - kultura jidysz zniszczona została pod koniec lat czterdziestych, razem z jej obrońcami, zaś w Stanach Zjednoczonych po prostu znikła w miarę odchodzenia starszych pokoleń" ${ }^{\prime 2}$. Pomimo tego jidysz ciągle jeszcze da się usłyszeć w dzielnicach ortodoksyjnych, w Izraelu oraz Stanach Zjednoczonych. „Szacuje się, że ponad $10 \mathrm{mln}$ osób używało aż do wybuchu II wojny światowej rozmaitych odmian jidysz, a na początku XXI w. można się doliczyć jedynie kilkuset tysięcy, głównie wśród haredim (»bojący się Boga«, czyli osoby ściśle przestrzegające przepisów religijnych). Kultura ludowa zanikła całkowicie; została unicestwiona, zaś wszelka nadzieja na jej wskrzeszenie jest daremna, ponieważ - jak pisał Sand - nie istnieje możliwość przywrócenia do życia określonej kultury czy języka. Roszczenia syjonizmu do odrodzenia starożytnego języka hebrajskiego i kultury »Ludu Księgi« wywodzą się z nierealnego poszukiwania odniesień narodowych wbijanych do głowy pokoleniom Izraelczyków i syjonistów na całym świecie" ${ }^{\prime 4}$.

„W realiach życia w Izraelu kultura jidysz była - jak to określiła Anita Shapira - tylko śladem po społeczności, która przestała istnieć" ${ }^{44}$. Praca Haima Maora z lat 2006-2007, zatytułowana מאמע-לשון / Mother Tongue, najlepiej chyba oddaje napięcie pomiędzy jidysz a hebrajskim w pierwszych latach istnienia Państwa Izrael. Jest to tkanina w kwiecisty wzór, która niegdyś należała do matki artysty. Jej krawędź traci kolor, gdyż materiał pochodzi z walca z końca linii produkcyjnej. Na materiale znajduje się czarna aplikacja - fraza מאמע-לשון. Czcionka jest charakterystyczna dla Siduru, co przywołuje skojarzenia z modlitwą. Zdanie מאמע-לשון w jidysz oznacza po hebrajsku שפת אם (czyt. sfat am), czyli „język matki”, ale również „język ojczysty”. Słowo מאמע (czyt. mame) w jidysz to "matka”. Natomiast wyraz לשון (czyt. laszon) w hebrajskim to ,język”. Jeśli pozostać wiernym poprawnemu zapisowi w jidysz, powinno się użyć słowa לושן (czyt. luszen) - מאמע-לושן (w innym miejscu znajduje się litera „waw” - ו). Jednak pośpieszne czytanie, jeśli oczywiście odbiorca zna jidysz, sprawi, że przeczyta on i tak automatycznie: מאמע-לושן. „Ta praca jest dla mnie - mówił artysta - bardzo sentymentalna, ponieważ znalazłem ten kawałek tkaniny po śmierci matki i dałem mu nowe życie"45. מאמע-לשון / Mother Tongue prowokuje pytanie o to, który właściwie język jest „językiem ojczystym” dla sporej części izraelskiego

\footnotetext{
${ }^{41}$ A. Oz, F. Oz-Salzberger: Żydzi i słowa..., s. 205.

${ }^{42}$ A. Shapira: Historia Izraela..., s. 177.

${ }^{43}$ Sh. SAnd: Dlaczego przestałem być Żydem..., s. 62.

${ }^{44}$ A. Shapira: Historia Izraela..., s. 249.

${ }^{45}$ R. Jакuвоwicz: Midrasz wizualny..., s. 10.
} 
społeczeństwa, dla dzieci uchodźców z Europy, którzy próbowali odnaleźć się w obcym kulturowo świecie, co tak znakomicie uchwycił Amos Oz w książce zatytułowanej Opowieść o miłości i mroku ${ }^{46}$. „Historia traktowania języka jidysz $\mathrm{w}$ Izraelu to historia polityki tygla w miniaturze, polityki, której zagorzali zwolennicy wierzyli, że imigranci ze wszystkich diaspor muszą wyrzec się - natychmiast i bez wahania - kultur i tradycji, które przywieźli ze sobą, a w ich miejsce przyjąć miejscowy etos i kulturę. Taka polityka była pozbawiona realizmu. W rzeczywistości imigranci tworzyli - pisała Anita Shapira - kulturowe »nisze«, zaspokajające ich potrzeby i pragnienia. Nisze te nie miały zastąpić kultury izraelskiej, ale istniały jako "poletka Pana Boga « należące do imigrantów z różnych diaspor" ${ }^{\prime 27}$. Owe "nisze” nie były jednak w stanie ochronić ani języka, ani związanej z nim kultury.

Jak spostrzegł Shlomo Sand, „pionierzy syjonizmu dążyli do stworzenia nowego wizerunku Żyda, zrywającego ze światem ludowej kultury swoich rodziców i przodków, a także ze światem małych miasteczek, stanowiących ich

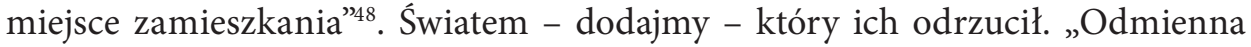
religia - zarówno zespół wierzeń, jak i praktyki - czyniła ich [Żydów - R.J.] przedmiotem przesądów i zabobonów. Nawet XIX-wieczna emancypacja, która otworzyła przed Żydami drogę do integracji ze społeczeństwami, w których żyli, nie zniosła tej odrębności. Umacniał ją bowiem - pisała Ruth Ellen Gruber chrześcijański, religijny "antyjudaizm « i polityczny rasistowski antysemityzm, zapoczątkowany pod koniec XIX w. Zagłada dopełniła dzieła"49. Europa nadal odrzuca Żydów, czego dowodzą odradzające się na Starym Kontynencie nacjonalizm oraz faszyzm, choć - jak przypomniała Gruber: „Parlament Europejski w dziewięć lat po uchwaleniu rezolucji z 1987 r., dotyczącej wkładu Żydów do kultury europejskiej, wydał dokument, w którym stwierdza się, że kultura jidysz była w Europie »czynnikiem umożliwiającym postęp intelektualny i jednocześnie składnikiem poszczególnych kultur narodowych «" 50 . W pracy zatytułowanej, również w jidysz, איך בין איין איד I am a Jew (cykl z lat 2006-2008) napis w formie aplikacji pojawia się na wojskowej tkaninie służącej do kamuflażu. Nie jest to jednak wzór z materiału wykorzystywanego przez armię izraelską, a typowy kamuflaż zimowy, przydatny w Europie. איך בין איין איד (czyt. „ich bin ein jid”, czyli „jestem Żydem”) to praca o podejmowanych przez europejskich Żydów próbach asymilacji, najczęściej daremnych, albowiem społeczności, w których żyli, i tak rozpoznawały ich i dyskryminowały jako Żydów; to także wypowiedź o dość powszechnym - zwłaszcza w Europie Wschodniej - ukrywaniu po drugiej woj-

${ }^{46}$ Por. A. Oz: Opowieść o miłości i mroku. Przeł. L. Kwiatkowski. Warszawa 2005.

47 A. Shapira: Historia Izraela..., s. 294.

48 Sh. SAND: Dlaczego przestałem być Żydem..., s. 62-63.

${ }^{49}$ R.E. Gruber: Odrodzenie kultury żydowskiej w Europie. Przeł. A. NowakowsKa. Sejny 2004, s. 57.

${ }^{50}$ Tamże. 
nie światowej żydowskiej tożsamości. Rozwinięciem tej pracy jest druga pod tym samym tytułem: איך בין איין איד, zrealizowana tym razem na materiale w niebieskie pasy, który przypomina talit (tałes) lub izraelską flagę. W tym przypadku „jestem Żydem” ewidentnie wyraża dumę ze swojej tożsamości, religii i narodu. Zastanawia tylko, dlaczego zamiast hebrajskiego napisu אני יהודי (czyt. ani jehudi, czyli, איך בין איין איד Czy westem Żydem”) Maor użył napisu w jidysz sposób pragnie wyrazić swój związek z diasporą, tradycją europejską odchodzącą wraz z umierającym pokoleniem jego rodziców? Czy jest to może raczej sugestia, że ocalałym i ich rodzinom trudno było włączyć się w powszechny entuzjazm towarzyszący budowie państwa i tworzeniu nowego człowieka, że nigdy nie zdołali do końca zintegrować się ze społeczeństwem izraelskim, że na zawsze pozostali obcymi pośród swoich? Realizacja Maora stanowi również pytanie o żydowskość projektu syjonistycznego. „Syjonizmowi udało się ukształtować nowy naród wyposażony w nowy język, odróżniający się od języka żydowskich przodków i antynarodowych koncepcji, do których ci ostatni się odwoływali. Ten naród posiadał teraz swoją ojczyznę, mimo że nie bardzo wiadomo, jakie są jej dokładne granice; dysponował ponadto jednolitą kulturą, chociaż nie zawsze zdawał sobie sprawę, w jakim stopniu nie jest ona - pisał Sand - żydowska. Sukcesy odniesione przez kulturę izraelską i nowy język hebrajski sprzyjały atmosferze pewnego odprężenia, jakie nastąpiło w połowie lat 70. XX wieku. Liczne elementy $\mathrm{z}$ minionej kultury jidysz lub arabskiej już nie były zagrożeniem dla wytycznych władz narodu i wkrótce zaczęto je postrzegać jako wyraz folkloru, godny akceptacji i pochwały... oczywiście, z pewną dozą ostrożności. Ale można już było przyznawać się do tęsknoty za jidyszkeit, zaś arabskie melodie pojawiały się coraz częściej w izraelskiej muzyce wzbogaconej refrenami ze Wschodu i znad Morza Śródziemnego" ${ }^{\text {11 }}$. Dawid Ben-Gurion nie żywił - podkreślał Szimon Peres - nienawiści do diaspory jako sytuacji ( gola), ale do „mentalności diaspory” (galutijut) ,jako skłonności do kompromisów, do uginania się przed wichrami losu” ${ }^{2}$. Jak spostrzegł Tom Segev: „Wbrew marzeniom ojców-założycieli, większość Izraelczyków okazuje przywiązanie do znienawidzonej przez ideologów syjonizmu »zdegradowanej« mentalności wygnania. Z biegiem lat odkrywają oni na nowo swoje żydowskie korzenie i zwracają się w stronę tradycji”" ${ }^{53}$.

Praca Haima Maora z 2010 roku, zatytułowana מילים מסומנות / Marked Words (czyt. milim mesumanot, czyli „słowa naznaczone”), to sześć czarno-białych obrazów, na których namalowane zostały wyrazy w jidysz. Kolejno:

א-בלינדער (czyt. a-blajnder, czyli „ślepy”)

א-קצטניק (czyt. a-kacetnik, czyli „więzień obozu”)

${ }^{51}$ Sh. SAnd: Dlaczego przestałem być Żydem..., s. 78-79.

${ }^{52}$ Por. Ben Gurion..., s. 95.

${ }^{53}$ T. Segev: Izrael po procesie Eichmanna. Przeł. A. Czarnacka. „Le Monde Diplomatique” 2008, nr 5 (27), maj (edycja polska), s. 7. 
א-משיגינער (czyt. a-meszugener, czyli „wariat”)

אינווליד (czyt. inwalid, czyli ,inwalida”)

נישט פון אונזערער (czyt. nicht von unserer, czyli „nie od nas”)

פון דר לענר (czyt. von der lager, czyli ,z lagru”)

Te słowa Maor często słyszał w rodzinnym domu. Rodzice opisywali w ten sposób znajomych, na których - w ich przekonaniu - trzeba było uważać, ciążył na nich bowiem pewien rodzaj ułomności, będącej konsekwencją obozowej przeszłości, co czyniło ich podejrzanymi i w jakiś sposób niebezpiecznymi. Owa nieufność do innych ocalałych jest charakterystyczna dla ofiar Zagłady.

Podobny formalnie tryptyk z 2011 roku, zatytułowany מחקר אטימולוגי / Etymological Study, składa się z trzech niewielkich, niezwykle oszczędnych obrazów. Na pierwszym widnieje czarny napis na jasnym tle, komunikat w języku hebrajskim: אושויץ או שוויץ (czyt. auschwitz o szwajc, czyli „Auschwitz albo Szwajcaria"), na drugim, środkowym, napis w języku niemieckim, charakterystyczną szwabachą: Auschwitz Oder Die Schweiz, na trzecim napis: Ausch - witz Moschkowitz. Praca אושויץ או שוויץ odnosi się do sposobu, w jaki naziści próbowali zmylić ludzi - tak, żeby myśleli, że jadą do Szwajcarii, a nie do obozu zagłady. „Pokazuję, że jest coś w samym słowie, co - mówił Haim Maor - ujawnia dodatkowe znaczenia. W samym słowie jest już zawarta jego tragedia, jest zawarte kłamstwo nazistów" "54. Szwajcaria jawiła się jako bezpieczne miejsce schronienia, dlatego żydowscy uchodźcy z okupowanych krajów starali się tam, za wszelką cenę, dostać. Tymczasem zamknięto przed nimi granice. Byli oni wyłapywani i odsyłani - oddawani w ręce nazistów. Następnie zaś trafiali do obozów zagłady w Europie Wschodniej. W ten sposób droga do „szwajc” stała się drogą do Auschwitz. Jean Ziegler zwrócił uwagę na podwójne standardy, jakie stosowała Szwajcaria: „Podczas gdy odsyłała proszących o pomoc Żydów, to nadal głosiła zasady powszechnej solidarności” ${ }^{5}$. Liczbę Żydów, którym „neutralna” Szwajcaria odmówiła przyjęcia, szacuje się na sto tysięcy. „Władze, dowództwo armii, policja kantonalna, tysiące funkcjonariuszy, członków straży granicznej dołożyły swój wkład - stwierdził Ziegler - w nazistowskie ludobójstwo" ${ }^{56}$. W trakcie wojny szwajcarscy bankierzy odegrali rolę paserów finansujących Trzecią Rzeszę. Ziegler postawił tezę, że „prowadząc pranie złota zrabowanego przez nazistów z banków centralnych okupowanych krajów lub wydartego ofiarom obozów zagłady, szwajcarscy bankierzy przyczynili się do przedłużenia II wojny światowej"57. Właśnie podczas wojny ugruntowała się dzisiejsza pozycja szwajcarskich banków. Natomiast po niej ograbiono konta ofiar Holokaustu, instrumentalizując prawo o tajemnicy bankowej. Na ostatnim obrazie nazwisko „Moschkowitz” zostało zestawione z wyrazem „Auschwitz”. „U Żydów aszkenazyjskich istnieje zwyczaj

\footnotetext{
54 R. Jakubowicz: Midrasz wizualny..., s. 9.

55 J. Ziegler: Szwajcaria, złoto i ofiary. Przeł. E. Cylwik. Warszawa 2016, s. 327.

56 Tamże, s. 338.

57 Tamże, s. 390-391.
} 
nadawania dziecku imienia jednego ze zmarłych przodków, aby jego spełnione życie - spostrzegł Leo Trepp - było dla młodego człowieka wzorem i żeby podkreślić ciągłość następujących po sobie pokolenn" ${ }^{8}$. Haim Maor nie posługuje się już ani imieniem Benjamin, ani swoim polskim rodowym nazwiskiem. Zostało ono TAM - w Auschwitz. „Hebrajskie nazwisko uwalniało od etnicznej tożsamości z diaspory i tworzyło - pisała Anita Shapira - most do rodzącego się spoleczeństwa izraelskiego" ${ }^{\circ 9}$. Ale hebraizowanie nazwisk było w przypadku tysięcy Izraelczyków nie tylko zadośćuczynieniem oczekiwaniom społecznym (umacnianie kultury hebrajskiej), lecz również wyrazem głębokiej potrzeby uwolnienia się od przytłaczającego ciężaru diaspory, symbolicznym odrzuceniem starej tożsamości i przyjęciem nowej, a tym samym odcięciem się od przeszłości, z którą na siłę chcieli ich zespolić rodzice, nadając imiona po zamordowanych podczas Zagłady przodkach. W geście zestawienia swego brzmiącego wschodnioeuropejsko nazwiska: Haim Benjamin Moshkovitz, z nazwą obozu koncentracyjnego, którego końcówka to również „witz” (niem. „dowcip”, „żart”), jest jakiś rodzaj natręctwa, a nawet perwersji. A jednocześnie to trudne, ale konieczne, przyznanie, że krewny, którego nazwisko nosił Haim Maor, zginął w Auschwitz-Birkenau. „Ludzka wyobraźnia po Auschwitz - pisał Alvin H. Rosenfeld - po prostu nie jest taka sama jak przedtem. Ujmując rzecz inaczej, samo włączenie nazwy »Auschwitz« do naszego słownika dowodzi, że wiemy teraz o czymś, czego wcześniej nie byliśmy sobie w stanie nawet wyobrazić" 60 .

Częścią wystawy zatytułowanej תשדורת מאושויץ-בירקנאו לחאן בירושלים Message from Auschwitz-Birkenau to the Chan in Jerusalem (1986), prezentowanej w budynku Jerusalem Khan Theatre (החאן הירושלמי), był obraz przywołany ze zbiorowego imaginarium Holokaustu przedstawiający nagich mężczyznę i kobietę na chwilę przed egzekucją, wstydliwie zasłaniających dłońmi łona. Scenie towarzyszył napis w języku hebrajskim העבודה משחרת (czyt. haawoda meszachreret, czyli "praca czyni wolnym” - tłumaczenie niemieckiej formuły „Arbeit macht frei” widniejącej na bramach kilku nazistowskich obozów koncentracyjnych, w tym nad bramą Auschwitz I). „Arbeit macht frei” przetłumaczone na hebrajski brzmi zdecydowanie mniej złowieszczo niż tytuł znanego obrazu Franka Stelli z 1967 roku $^{61}$, jednak przekaz pozostaje ten sam.

„Niektóre dzieci ocalałych z Holocaustu identyfikowały się ze słabymi i bezbronnymi ofiarami, inne przepełniała złość z powodu upokorzeń, których doświadczyli od nazistów ich rodzice, nie mając najmniejszej możliwości przeciw-

${ }^{58}$ L. TREPP: Żydzi..., s. 404.

59 A. Shapira: Historia Izraela..., s. 292.

${ }^{60}$ A.H. Rosenfeld: Podwójna śmierć. Rozważania o literaturze Holocaustu. Przeł. B. KRAwcowicz. Warszawa 2003, s. 27.

${ }^{61}$ Por. L. Saltzman: Awangarda i kicz raz jeszcze. O estetyce reprezentacji. Przeł. K. BoJARSKa. „Literatura na Świecie” 2004, nr 1-2 (390-391), s. 201-215. Por. także M. Hussakowska: Minimalizm. Kraków 2003, s. 157. 
działania i walki. Ta złość - pisała Batya Barutin ${ }^{62}$ - doprowadziła drugie pokolenie do potrzeby kompensacji sytuacji rodziców pozycją siły i utożsamieniem się z katem. Jeszcze inni próbowali zbliżyć się do dzieci sprawców Holocaustu, aby zrozumieć, w jaki sposób radzą sobie z przeszłością rodziców i podjąć próbę pojednania. W realizacjach artystycznych przedstawiciele drugiego pokolenia [...], utożsamiają się z ofiarami, przedstawiają siebie z pozycji siły jako katów; albo pokazują złożoność relacji kat-ofiara, aby dać wyraz przekonaniu, że akt przemocy wiąże się z bezsilnością" ${ }^{63}$. W 1978 roku w Ha'Kibbutz Gallery w Tel Awiwie Haim Maor zrealizował wystawę zatytułowaną אות קיל / The Mark of Cain (czyt. ot kain, czyli „znamię Kaina”), w której odniesienia do Holokaustu splatały się ze współczesnością. „Wstydzisz się, bo żyjesz zamiast kogoś innego? A dokładniej mówiąc, zamiast człowieka szlachetniejszego, wrażliwszego, mądrzejszego, pożyteczniejszego, więc bardziej zasługującego na życie niż ty? Nie możesz tego wykluczyć [...] To tylko domysł, tylko ślad podejrzenia, że Każdy - pisał Primo Levi - jest Kainem dla swojego brata, że każdy z nas (tym razem używam słowa "my« w sensie znacznie szerszym, wręcz uniwersalnym) zajął czyjeś miejsce i żyje zamiast niego"64. Częścią wspomnianej wystawy była instalacja קין נקי כסיים Innocent Cain (czyt. kain naki kapajim, czyli „Kain niewinny”). Zdanie to, zapisane kolorem białym, zestawione zostało z frazą קין קטל (czyt. kain katal, czyli „Kain zamordował”), zapisaną z kolei kolorem czarnym. „Musimy mieć w pamięci, że to jest pierwsze morderstwo. Kain jeszcze nie wie, że istnieje coś takiego. Nie wie, że można zabić; że - jeśli tłucze się kogoś dostatecznie mocno - zatłucze się go na śmierć. Nie wie, co to jest śmierć i uśmiercanie. Nie motyw rozstrzyga, tylko sposobność. W zawierusze niezdecydowania - pisał Martin Buber - Kain rzuca się i bije w momencie najsilniejszego pobudzenia i najsłabszego oporu. Nie morduje. Zamordował" ${ }^{6}$. Maor zastanawiał się, czy w myśl obowiązujących we współczesnym sądownictwie przepisów Kain nie zostałby oskarżony o nieumyślne spowodowanie śmierci - zamiast o morderstwo ${ }^{66}$. Częścią wystawy było również tytułowe czarno-białe zdjęcie-obiekt przedstawiające twarz mężczyzny naznaczonego piętnem kainowym. Oczy zasłonięte zostały czarnym materiałem, na którym znajdował się żółty znak graficzny. Przypomnijmy, że w sztuce chrześcijańskiej, począwszy od IX wieku, prezentowano personifikację Synagogi pod postacią kobiety z opaską na oczach i złamaną włócznią w ręku, Eklezji zaś jako królowej z koroną, krzyżem i kielichem. „Najwcześniejszy średniowieczny sposób piętnowania heretyków i starowierców polegał - przypominają Paweł Dobrosielski i Karolina Sulej - na znaczeniu ubrań za pomocą czerwonego kółka

${ }^{62}$ Nazwisko tej autorki w katalogu Biblioteki Narodowej Izraela funkcjonuje w formie Batya Brutin.

${ }^{63}$ B. Barutin: Haim Maor - znicz pamięci. Artysta z drugiego pokolenia po Holocauście. Przeł. B. Juszczy . „Pro Memoria” 2009, nr 2 (29), s. 142.

${ }^{64}$ P. Levi: Pograżeni i ocaleni. Przeł. S. Kasprzysiak. Kraków 2007, s. 97-98.

${ }^{65}$ M. Buber: Obrazy dobra i zła. Przeł. M. Masny. Gliwice 2017, s. 61.

${ }^{66}$ Por. R. Jakubowicz: Midrasz wizualny..., s. 9. 
z białym środkiem lub żółtą łatą (Judenfleck). Kolor żółty, na mocy skojarzenia z szatą Judasza, był kolorem hańby. Symboliczne piętno było więc od początku widomym znakiem kulturowej segregacji”" ${ }^{\text {". }}$. W 1215 roku na Soborze Laterańskim IV postanowiono, że Żydzi muszą nosić na odzieniu żółtą łatę wyróżniającą ludzi wyjętych spod prawa, a na głowach szpiczaste kapelusze. Żółty kolor oraz trójkątny kształt w pracy Maora w oczywisty sposób przywołują opaski z gwiazdą Dawida, które podczas drugiej wojny światowej zmuszeni byli nosić Żydzi w gettach i obozach koncentracyjnych. Znak jest przetworzoną hebrajską literą $>$ (czyt. kuf). Litera p to odniesienie do tytułowego קין (czyt. Kain). Ale może ona sugerować również - co podkreśla artysta - inne słowa, na przykład קורבן (czyt. korban, czyli „ofiara”), קיבוצניק (czyt. kibucnik, czyli w języku potocznym „członek ruchu kibucowego”), קומוניסט (czyt. komunist, czyli „komunista”) czy קולוניאליסט (czyt. kolonialist, czyli „kolonizator”). „Wkroczenie w historię, jak określali to niektórzy pionierzy, prowadziło do tego, że Żydzi znaleźli się po tej stronie barykady, którą dotychczas znali słabo: zabijających a nie zabijanych. Dotąd bywali przecież wyłącznie bezbronnymi ofiarami” ${ }^{68}$. Wyraz „kolonizator" (קולוניאליסט) wpisuje się w kontekst palestyńskiej tragedii - Nakby, i wiąże się z kwestią uznania krzywd wyrządzonych i nadal wyrządzanych Palestyńczykom. Taka konotacja znaku-litery p, umieszczonej na opasce zasłaniającej oczy brodatego mężczyzny, łączy się z psychologicznym lękiem przed rewizją dominujących historycznych interpretacji wydarzeń z 1948 roku i ich obecnych reperkusji, co próbują przepracować tzw. nowi historycy. Palestyńczycy słusznie domagają się uznania ich cierpień. „Dla izraelskich Żydów oznaczałoby to naturalnie - pisał Ilan Pappé - podważenie ich wyjątkowego statusu ofiar. To z kolei miałoby nie tylko następstwa polityczne na skalę międzynarodową, lecz także zapewne znacznie dalej idące konsekwencje moralne i egzystencjalne dla izraelskiej żydowskiej psyche: izraelscy Żydzi musieliby przyznać, że stali się lustrzanym odbiciem tego, czego sami bali się najbardziej”ø9.

Praca z 2010 roku, zrealizowana wspólnie z palestyńskim artystą Mohammadem Saidem Kalash'em ${ }^{70}$, zatytułowana יהודי ( Good Jew (czyt. jehudi tow, czyli „dobry Żyd”), to ośmiokątna forma z drewna, wykonana w technice forniru. Znajdują się na niej dwie ośmioramienne gwiazdy oraz podobizna profilu Haima Maora na tle owalnego kształtu wypełnionego kolorem niebieskim. Przy każdym z kątów figury geometrycznej, jaką tworzy podobrazie, znajduje się jedna czarna litera. Zanim połączymy litery i odszyfrujemy treść, czyli tytułowe zdaיהודי טוב, wydaje się, że pełnią one tylko funkcję dekoracyjną. W XVIII wieku

${ }^{67}$ P. Dobrosielski, K. Sulej: Zwierzę. W: Ślady Holokaustu..., s. 513.

68 A. Oz, F. Oz-Salzberger: Żydzi i słowa..., s. 171.

${ }^{69}$ I. PAppé: Czystki etniczne w Palestynie. Przeł. A. SAK. Warszawa 2017, s. 318.

${ }^{70}$ Mohammad Said Kalash podarował Haimowi Maorowi swoje dzieło (pracuje on w technice forniru, tworząc obiekty o charakterystycznej ornamentyce), prosząc go, by wykonał jakiś artystyczny gest. Maor namalował litery układające się w napis „יהודי טובי 
w mowie potocznej zamiast hebrajskiego terminu cadik powszechnie używano określenia w jidysz giter Jid, „dobry Żyd”. „Dobry Żyd - pisał Gershom Scholem to taki Żyd, jaki powinien być. Żyd starający się w swoim życiu sprostać regułom judaizmu. Wyrażenie w języku jidysz odpowiada hebrajskiemu zwrotowi jehudi kasher często pojawiającemu się wówczas w pismach moralnych” "11. „W narracji zdominowanej przez większość »dobry Żyd« zajmuje - pisali Elżbieta Janicka i Tomasz Żukowski - jedyne akceptowane miejsce: kogoś, kto potwierdza wyobrażenia dominujących - w tym wypadku ich lęki i fobie - na temat grupy, do której sam należy”" Frazę „dobry Żyd”, używaną w czasie Zagłady, można zamienić na określenie „dobry Arab” (ערבי טוב, czyt. arawi tow). „Miliony Palestyńczyków na terenach okupowanych - sygnalizował Amos Oz - są notorycznie upokarzane, wszyscy są pozbawieni wolności i praw"73. Warto w tym kontekście zwrócić uwagę na opresyjną politykę klasową realizowaną przez Izrael wobec społeczności palestyńskiej, w związku z którą większość jej członków - po aneksji Zachodniego Brzegu - to nisko opłacani robotnicy rolni i budowlani. W taki oto sposób odniesienia do Holokaustu nakładają się i przenikają ze współczesnymi problemami życia w Izraelu, gdzie - w obliczu nieustannie toczących się konfliktów - role ofiary i oprawcy czy też agresora, uchodźcy i okupanta, upokarzającego i upokarzanego, wyzyskującego i wyzyskiwanego, łatwo mogą zostać odwrócone, wymagając przedefiniowania. Jak pisała Idith Zertal: „[...] narracja, w której Szoa wyniesione jest do rangi najwyższej władzy, nadającej sens istnieniu Izraela i permanentnemu konfliktowi w regionie, może niekiedy wymknąć się spod kontroli jej interpretatorów i apologetów i nagle objawić groźną i skrywaną prawdę o potędze izraelskiej i jej ofiarach, prawdę o niepokojącej bliskości między katami i ofiarami, pomiędzy tym, co ludzkie, i tym, co nieludzkie, a także fakt, że zła nie da się przypisać tej czy innej grupie ludzi" ${ }^{74}$. Göran Rosenberg spostrzegł, że lekcją nazizmu było między innymi to, że człowiek, jeśli nie chciał stać się ofiarą, musiał zmienić się w kata. „Ile jego ofiar żyło w przekonaniu, że w tym punkcie - pisał - nazizm miał rację"75. Rolą artysty, zwłaszcza zaś artysty-proroka, którą wyznaczył sobie Haim Maor, jest przestrzeganie przed konsekwencjami, jakie powoduje nacjonalizm w każdej wersji, oraz wyrażenie sprzeciwu wobec traktowania Zagłady jako uzasadnienia dla istnienia Państwa Izrael i dla budowy jego militarnej potęgi, czyli argumentu obecnego, ponieważ użytecznego $\mathrm{w}$ doraźnych sporach politycznych, a także figury retorycznej często przywoływanej w kontekście konfliktu bliskowschodniego. Słowo

${ }^{71}$ G. Scholem: O mistycznej postaci bóstwa. Przeł. A.K. HaAs. Warszawa 2010, s. 133.

72 E. Janicka, T. Żukowski: Przechwycenie dokumentu: Po-lin Joanny Dylewskiej (2008). W: Ciż: Przemoc filosemicka? Nowe polskie narracje o Żydach po roku 2000. Warszawa 2016, s. 67.

73 A. Oz: Do fanatyków..., s. 115.

74 I. Zertal: Naród i śmierć. Zagłada w dyskursie i polityce Izraela. Przeł. J.M. KŁoczowski. Kraków 2010, s. 289.

75 G. Rosenberg: Kraj utracony..., s. 282. 
"טובים" (czyt. towim, czyli „dobrzy”) miało jeszcze jedno znaczenie - w ten sposób określano „materiał ludzki” sprowadzany do Palestyny; odnosiło się ono do jednostek pełnowartościowych w odróżnieniu od „słabizny”, czyli tych, którzy wyrwali się, okaleczeni fizycznie i psychicznie, z piekła Zagłady ${ }^{76}$.

Postawę Haima Maora, artysty drugiego pokolenia, możemy interpretować w kontekście wprowadzonego przez Marianne Hirsch pojęcia postpamięci, która jest oddzielona od pamięci przez dystans pokoleniowy oraz od historii przez głębokie osobiste relacje. „Postpamięć odzwierciedla skomplikowaną oscylację między ciągłością a zerwaniem. Ale nie chodzi tu o jakiś nurt, metodę czy ideę. To struktura transferu traumatycznej wiedzy i doświadczenia między pokoleniami lub ponad nimi. Kon sekwencja powrotu traumy (nie mylić z zespołem stresu pourazowego) w skali - pisała Marianne Hirsch - całego pokolenia"77. Dlatego też amerykańska badaczka posługuje się pojęciem „postpokolenie”. „Ich [czyli postpokolenia - R.J.] pamięć została - pisała Joanna Krakowska - skolonizowana przez wspomnienia poprzednich pokoleń, ukształtowanych przez traumatyczne doznania. Istotą postpamięci jest przemieszczenie: wydarzenia z przeszłości są emocjonalnie reaktualizowane w innym miejscu i ze znaczącym opóźnieniem w stosunku do okoliczności, w których rzeczywiście zaistniały"78. Czym jest postpamięćć „Postpamięć to relacja łącząca pokolenie biorące udział w kulturowej lub kolektywnej traumie z kolejnym, które "pamięta« je wyłącznie dzięki opowieściom, obrazom i zachowaniom, wśród których dorastali. To doświadczenie zostało im przekazane w tak emocjonalny sposób, że wydaje się fundamentem ich własnej pamięci. Postpamięć nie wiąże się zatem z przeszłością, która dosłownie powraca. Ona powraca w postaci inwestycji wyobrażeń, różnego rodzaju projekcji czy twórczości artystycznej. Dorastanie w kręgu tak potężnych, odziedziczonych wspomnień oraz opowieści o czasach, kiedy nas jeszcze nie było na świecie, lub nie mieliśmy świadomości, co się wokół nas dzieje, niesie ze sobą niebezpieczeństwo wyparcia czy wręcz wymazania własnych opowieści i doświadczeń przez wspomnienia poprzedniego pokolenia. Wpływać na to będą pośrednio te traumatyczne doświadczenia, które nadal nie pozwalają się zrekonstruować $\mathrm{w}$ formie narracji, a tym samym zrozumieć. Doszło do nich w przeszłości, lecz ich efekty nadal trwają. Jak mi się wydaje, na tym właśnie - pisała Hirsch - polega doświadczenie postpamięci i proces jej wytwarzania"79. Zjawisko postpamięci opiera się, zdaniem badaczki, na trzech składowych: „bezpośredniego obcowania z ludźmi obciążonymi pamięcią o traumatycznych zdarzeniach”, „obecności w dostępnych archiwach lub przestrzeni społecznej znaków o charakterze indeksalnym” oraz „zdolności

76 Por. tamże, s. 269.

77 M. Hirsch: Pokolenie postpamięci. Przeł. M. Borowski, M. Sugiera. „Didaskalia. Gazeta Teatralna” 2011, nr 105, s. 29.

78 J. Krakowska: Dziecko. W: Ślady Holokaustu..., s. 151.

79 M. Hirsch: Pokolenie postpamięci..., s. 29. 
wywołania wyobrażeniowego wstrząsu, rozsadzającego symboliczny porządek zastanej kultury”80. Postpamięć jest „silną i bardzo szczególną formą pamięci, gdyż nie opiera się na własnych doświadczeniach, ale jest zapośredniczona przez wyobraźnię oraz kreację artystyczną. Jest jakby uzupełniana - zdaniem Izabeli Kowalczyk - przez wyobrażeniowe czy artystyczne reprezentacje. Jest doświadczana przez potomków ludzi ocalałych z Zagłady i tym samym odnosi się do tych wydarzeń, które położyły się tragicznym cieniem nie tylko na życiu ocalałych, ale i następnych pokoleń, a były tak silne, że przyćmiły wszelką inną pamięć, ale zarazem nigdy nie zostaną $\mathrm{w}$ pełni przyswojone i zrozumiałe. Postpamięć ujawnia się na zasadzie przemieszczenia - $\mathrm{w}$ innym miejscu oraz ze znacznym opóźnieniem w stosunku do wydarzeń, do których się odnosi. Jest to też pamięć obsesyjna i wybuchowa, niedająca spokoju i wytchnienia. Termin ten wydaje się odpowiedni do sztuki współczesnej, która odwołuje się do historycznych traum, rozdrapuje, pozornie tylko zagojone rany" ${ }^{\text {81. W }}$ twórczości Maora postpamięć diaspory nakłada się na postpamięć Zagłady, która z kolei przywoływana jest w kontekście krytyki heroicznej narracji syjonizmu oraz entuzjazmu towarzyszącego budowie nowego państwa.

Haim Maor spędził dzieciństwo w Holonie, w cieplarnianych warunkach żydowsko-wschodnioeuropejskiego domu, otoczony przez nadopiekuńczą rodzinę, ale też w atmosferze wszechobecnej tajemnicy i niedopowiedzeń. „Kiedy byłem małym chłopcem, dorastałem - pisał - w nowo powstałym mieście, położonym między piaszczystymi wydmami a ogromnymi moczarami, zamieszkanymi przez miliony żab. Nocą szakale wyły do księżyca, a w dzień krążył osierocony kruk. Różniłem się od wszystkich innych dzieci, powściągliwy, nieśmiały, marzyciel, szkicujący legendy i odległe panoramy, chłonący ból. Dom spowijała - wspominał artysta - głęboka cisza, przytłaczająca i posępna, cisza trzymająca na uwięzi zapomniane historie. Ale tu i tam - niemal ukradkiem słowa wymykały się z więzienia. Jednak, dobrze wiedziałem, że gdybym je wypowiedział - chociażby żartem - mogłyby spowodować katastrofę: na lewo, na prawo, Mengele, selekcja, gaz, krematorium. Strzeżone słowa, wydzielały woń dziwną, duszącą i obcą - jak wszystkie słowa pochodzące stamtąd"82. Wiele lat później, w 1988 roku, zestawił owe pozornie niewinne słowa w pracy / Forbidden Words. „Język rodziny, język ciała: niewerbalne i niekognitywne akty transferu zachodzą najwyraźniej w przestrzeni rodziny i często przybierają formę symptomów. Być może ich opisy sprawiły, że wydaje się nam, jakoby postpokolenie chciało wejść przemocą w rolę ofiary zastrzeżoną dla rodziców. To prawda, dzieci osób bezpośrednio dotkniętych zbiorową traumą dziedziczą przerażającą, nieznaną i nieprzewidywalną przeszłość

${ }^{80}$ Por. G. NizioŁek: Polski teatr Zagłady. Warszawa 2013, s. 77.

${ }^{81}$ I. Kowalczyк: Podróż do przeszłości. Interpretacje najnowszej historii w polskiej sztuce krytycznej. Warszawa 2010, s. 83-84.

${ }^{82}$ H. Maor: Zapomniane historie. Przeł. B. Juszczyk. „Pro Memoria” 2009, nr 2 (29), s. 126. 
skazanych na zagładę. Literatura, sztuka i świadectwa drugiego pokolenia powstały jako świadectwo prób przedstawienia długofalowych konsekwencji życia w bezpośredniej bliskości bólu, depresji i osamotnienia tych, którzy doznali historycznej traumy na wielką skalę. Powstały - twierdzi Hirsch - jako wynik dezorientacji dziecka i jego odpowiedzialności, chęci naprawienia szkód i świadomości, że jego własne życie stanowić może formę rekompensaty za niemożliwą do werbalizacji stratę rodziny, domu, poczucia przynależności i bezpieczeństwa w świecie" ${ }^{\prime 3}$. Wizualność przywołanej realizacji Maora przywodzi na myśl prace konceptualistów. Są w niej również czystość i rygor, charakterystyczne dla poezji konkretnej. Wyrazy zapisane w językach hebrajskim i angielskim, rozpisane równo, w trzech kolumnach, nabierają - w kontekście Holokaustu - przerażających referencji. Zaczynamy od אוכל-מזוודה-עבודה (czyt. ohel-mizwada-awoda, czyli „jedzenie-walizka-praca”), podążamy przez kolejnych dwanaście linijek, by dotrzeć do פחד-מספר-סוף (czyt. pachad-mispar-sof, czyli „strach-numer-koniec”). Batya Barutin w tekście zamieszczonym pierwotnie w książce pt. Haim Maor. The Faces of Race and Memory: Forbidden Library ${ }^{84}$, wydanej w 2005 roku przez Massuah - The Institute for the Study of the Holocaust, spostrzegła, że słowo "numer” (מספר, czyt. mispar) zastąpiło $\mathrm{w}$ tej pracy reprezentację wizualną numeru (w wielu realizacjach Haima Maora pojawia się obozowy numer jego ojca w formie cyfr). „Numer nie jest tu - pisała - uwypuklony, stanowi raczej część grupy słów, które reprezentują traumę Holocaustu, słów, których nie można było wypowiadać w domu Maora, w domach wielu ocalałych" 85 .

W pierwszej kolumnie (w wersji hebrajskiej) pojawiają się kolejno słowa: אוכל (czyt. ohel, czyli ,jedzenie") אהבה (czyt. ahawa, czyli „miłość”) אמא (czyt. ima, czyli „matka”)

אבא (czyt. aba, czyli „ojciec”) בגד (czyt. beged, czyli „ubiór") בית (czyt. bait, czyli „dom”) גדר (czyt. gader, czyli „płot”) חיים (czyt. chajim, czyli „życie”) זיכרונות (czyt. zichronot, czyli „wspomnienia”) ילדים (czyt. jeladim, czyli „dzieci”) גורל (czyt. goral, czyli ,los”) הובלה (czyt. howala, czyli „transport”) כאב (czyt. keew, czyli „ból”)

${ }^{83}$ M. Hirsch: Pokolenie postpamięci..., s. 31.

${ }^{84}$ Por. Haim Maor. The Faces of Race and Memory: Forbidden Library. Massuah - The Institute for the Study of the Holocaust, Kibbutz Tel Itzhak 2005.

${ }^{85}$ B. Barutin: Haim Maor..., s. 138. 
W drugiej:

מזוודה (czyt. mizwada, czyli „walizka”)

פרכבת (czyt. rakewet, czyli „pociąg”)

פיקוח (czyt. pikuach, czyli „inspekcja”)

כלבים (czyt. klawim, czyli „psy”)

מחנה (czyt. machane, czyli „obóz”)

סלקציה (czyt. selekcja, czyli „selekcja”)

עירום (czyt. irum, czyli „nagość”)

שיער (czyt. sear, czyli „włosy”)

שיניים (czyt. szinajim, czyli „zęby”)

עור (czyt. or, czyli „skóra”)

מקלחת (czyt. miklachat, czyli „prysznic”)

מגפיים (czyt. magafajim, czyli „buty”)

מספר (czyt. mispar, czyli „,numer”)

I w trzeciej, ostatniej:

עבודה (czyt. awoda, czyli „praca”)

קבודה (czyt. raew, czyli „głód”)

קורבן (czyt. korban, czyli „ofiara”)

הישרדות (czyt. hisardut, czyli „przetrwanie”)

השמדה (czyt. haszmada, czyli „eksterminacja”)

גו (czyt. gaz, czyli "gaz")

מוות (czyt. mawet, czyli „śmierć”)

שתיקה (czyt. sztika, czyli „cisza”)

עשן (czyt. aszan, czyli „dym”)

תפילה (czyt. tfila, czyli „modlitwa”)

נשמה (czyt. neszama, czyli „dusza”)

עד (czyt. ed, czyli „świadek”)

שכחה (czyt. szichecha, czyli „zapomnienie”)

סוף (czyt. sof, czyli „koniec”)

Trzy rzędy słów układają się w dość osobliwą lekcję języka hebrajskiego. Pomiędzy pierwszymi wyrazami, które poznajemy jako dzieci, jak אמא (czyt. ima, czyli „matka”), אבא (czyt. aba, czyli „ojciec”) czy בית (czyt. bait, czyli „dom”), i zarazem jednymi z pierwszych, których uczymy się, poznając obcy język, zapisane zostały takie jak השמדה (czyt. haszmada, czyli „eksterminacja”), które wytrącają nas z dobrego samopoczucia, powodując niepokój i kierując naszą uwagę ku obozom koncentracyjnym. Maor wprowadza w pozornie bezpieczne konteksty słowa mogące budzić lęk, a nawet grozę. „Artystyczne manipulacje, zasłony, ukrywanie i kamuflaż właściwe dla aktu twórczości artystycznej, są również najwłaściwszymi środkami ekspresji dla takiego artysty jak ja, dorastającego w domu dbającym o to, by rozmowę o Holocauście charakteryzowało - pisał Haim Maor - mądre wykorzystywanie kostiumów, masek i kamuflażu, tak by dzieci nie zrozumiały i rosły, że tak powiem, w zdrowym klimacie 
Izraela. Oczywiście, tak się nie stało" ${ }^{86}$. Wiele spośród użytych w tej pracy słów to wyrazy, których - jak wspominał Haim Maor, „nie wolno było wypowiadać w domu, bo drażniło to ojca albo smuciło matkę. Były to słowa, których się nie wypowiada. Na przykład »obóz koncentracyjny«, »komora gazowa«, »krematorium« i tak dalej. Były to dla rodziców słowa wstrząsające $\mathrm{z}$ emocjonalnego punktu widzenia"87. Gdy tylko zostawały nieopatrznie wypowiedziane - przenosiły TAM. Czytając kolejne wyrazy, orientujemy się powoli, że choć z pozoru wydają się niewinne, zwyczajne - opisują koszmar. Od tego momentu zaczynamy doszukiwać się w nich drugiego, ukrytego znaczenia. „Gdy przygotowywałem nową listę słów, przejrzałem cały słownik hebrajski i wybrałem te, które wydawały mi się odpowiednie, w kolejności alfabetycznej. Potem ułożyłem je - wspominał Haim Maor - według normalnego ludzkiego porządku życia - »ojciec«, "matka«, "płot«, »dzieci«, »dom«. Następnie kontynuowałem, używając takich słów jak »pociąg«, »obóz«, "prysznic« - o podwójnym znaczeniu. To jest właśnie to, co mnie interesuje - jak to samo słowo, o negatywnym wydźwięku dla pokolenia moich rodziców, które przeżyło Zagładę, może mieć wydźwięk pozytywny dla mojego pokolenia. Kiedy moja generacja mówi »obóz«, ma na myśli letni obóz ruchu młodzieżowego. Dla moich rodziców »obóz« to zawsze »obóz koncentracyjny«. Kiedy mówimy "pociąg«, to przypomina mi się »wycieczka do Jerozolimy«. Gdy byłem dzieckiem, jeździłem pociągiem do Jerozolimy i było to wspaniałe doświadczenie. Ale moim rodzicom słowo "pociąg« przypominało Auschwitz. Kiedy uświadomiłem sobie, że skojarzenia moje i rodziców, dotyczące tych samych słów, są różne, zrozumiałem, że to punkt wyjścia dla pracy "Zakazane Słowa«. Zrozumiałem, że ta różnica jest ważna nie tylko dla mnie, w moich relacjach z rodzicami, ale jest charakterystyczna dla całego pokolenia w Izraelu, które myśli inaczej niż generacja rodziców. W ten sposób praca otrzymała ogólną ramę konceptualną. Instalacja, poprzez środki werbalne i wizualne, ilustruje proces, który rozpoczął się całkiem normalnym życiem - »ojciec«, "matka«, »dzieci«, »dom« - i zmienił się w życie zniekształcone, koszmarne, zmierzające do gorzkiego końca. Gdy porządek alfabetyczny się komplikuje, słowa nabierają grozy - odzwierciedlając język eksterminacji. Odbiorca zaczyna rozumieć, że ta lista słów, tak bardzo banalnych i powszechnych, jest związana także z Shoa. Pokolenie, które doświadczyło Zagłady, rozpozna te słowa jako słowa zakazane, jakich nie wolno wypowiedzieć, słowa uderzające albo słowa, które wybierają nieświadomie. To była siła tej pracy. Ludzie rozumieli ją bez żadnych wyjaśnień" ${ }^{8}$. Jak łatwo zauważyć, brakuje tu wyrazu „cmentarz”. „Zagłada wyłączyła śmierć z semantycznego pola wytyczanego przez cmentarz, zerwała pisała Joanna Krakowska - jej związki ze słowami: "pogrzeb«, "pochówek",

${ }^{86}$ H. Maor (Moshkovitz): Sztuka i życie. Przeł. B. Juszczyк. „Pro Memoria” 2009, nr 2 (29), s. 129.

${ }^{87}$ R. Jакивоwicz: Midrasz wizualny..., s. 6.

${ }^{88}$ Tamże. 
"całun«, »żałobnicy«, »kadysz«, "grób«, »ohel«. W zamian zaoferowała właśnie konteksty frazeologiczne: "wagon«, "gaz«, »komin«, "popioły« i stworzyła nowe słowo: »ludobójstwo«. Cmentarz nierozerwalnie związał się z Zagładą swoim nieistnieniem - zbędnością w porządku przez nią wyznaczonym"89.

Częścią wspomnianej pracy była również plansza z piktogramami przedstawiającymi na przykład: dom, prysznic, chleb, bagaż. Zostały one zaprojektowane na wzór tych, które można znaleźć na każdym lotnisku, w hotelu czy we współczesnym centrum handlowym. Pośród nich pojawiają się także takie, które informują o niebezpieczeństwie, jak wyobrażenie czaszki oraz dwóch skrzyżowanych piszczeli, czy przedstawienia wprost nawiązujące do Zagłady, jak obrys bramy w Birkenau. „Ułożyłem je - mówił artysta - obok siebie, w rzędzie, tworząc słownik wizualny Holocaustu. I tak na przykład sylwetki mężczyzn i kobiet (pierwotnie przeznaczone do przedstawienia toalet - męskiej i damskiej) zamieniły się w znaki »ojciec $\mathrm{i}$ »matka«; piktogram przedstawiający piekarnię zamienił się w »chleb «, piktogram stacji kolejowej zamienił się w »wagon śmierci«, i tak dalej. Kiedy uporządkowałem je, one "rozmawiały« bez słów, i wyglądały jak znaki orientacyjne we współczesnym obozie śmierci: w prawo prysznic, w lewo do komory gazowej i do krematorium..." ${ }^{\text {90 }}$. To oczywiście odniesienie do oszustwa i kamuflażu nazistów mających uśpić czujność ofiar (krematorium jako „łaźnia”).

Doświadczenie Haima Maora jest doświadczeniem pokoleniowym. „Nigdy nie słyszałem od mojego ojca - mówił artysta - całej historii o Holocauście. Jedynie fragmenty, krótkie, niewyraźne zdania... krzyki w nocy..., pomruki wśród koszmarów..., tak dowiedziałem się, że mój ojciec był w Auschwitz w Sonderkommando, był członkiem komanda Żydów, którzy transportowali ciała z komór gazowych do krematoriów" ${ }^{\prime 1}$. Ojciec artysty zbiegł z obozu, po czym przyłączył się do partyzantów. Ocalał. W 1949 roku wyemigrował do Izraela. Matka, która w chwili wybuchu wojny miała dziewięć lat, również trafiła, razem z rodziną, do obozu. Jej matka wraz z trójką najmłodszych dzieci zdołała uciec. Rodzina ukrywała się między innymi w lasach. Z obozu dla dipisów (displaced persons, DPs) w Bergen-Belsen wyemigrowali do Izraela. Dziadek Maora ze strony matki, Efraim Rutter, był kamieniarzem, specjalizował się w nagrobkach. „Kiedy byłem dzieckiem, dziadek opowiadał mi, jak obrabiał płyty nagrobne w Polsce, na wsi. Były wśród nich płyty zwykłe i luksusowe płyty marmurowe z wygrawerowanymi, złoconymi literami, ozdobione lwami i kwiatami. Dziadek był mistrzem, o którego usługi zabiegano. W tamtych czasach - wspominał Maor - okoliczni możni zamawiali u niego projekty witraży do swoich majątków i płyty nagrobne" ${ }^{\prime 2}$. W czasie wojny brał udział w akcjach sabotażu przeciwko

${ }^{89}$ J. Krakowska: Cmentarz. W: Ślady Holokaustu..., s. 103.

90 R. Jакuвоwicz: Midrasz wizualny ..., s. 6.

${ }^{91}$ Cyt. za: B. Barutin: Haim Maor..., s. 132.

${ }^{92}$ H. Maor: Zapomniane historie..., s. 127. 
hitlerowcom. Gdy go złapano i poddano torturom, stracił - wskutek uderzenia pejczem w twarz - wzrok. Do tego faktu nawiązuje olejny tryptyk z 2010 roku, pt. שלושה מצבי עיוורון. סבה / Three Stages of Blindness (My Grandfather) (czyt. szlosza macawej iwaron. saba), którego pierwowzorem były trzy fotografie dziadka obozowe zdjęcie więźnia Bergen-Belsen nr 327, fotografia z karty imigranta, tzw. תדועת עולה (czyt. teudat ole), oraz z izraelskiego dowodu tożsamości, czyli תעודת זהות (czyt. teudat zehut) ${ }^{93}$. Spinające wszystkie te zdjęcia nity zostały namalowane w taki sposób, że przypominają kwiaty. „W wieku lat trzech Maor stał się - pisała Batya Barutin - oczami swojego dziadka i towarzyszył mu w drodze do miejsc, do których nie miał wstępu pies, np. do synagogi. Przewodnikiem dziadka był również popołudniami, aby pies mógł odpocząć" ${ }^{\prime \prime}$. Od starca właśnie dowiedział się wszystkiego o polskim sztetlu, życiu partyzantów i Zagładzie. „Mój niewidomy dziadek - wyznał artysta - nauczył mnie, że rasizm to choroba ludzi, którzy patrzą tylko oczami"95.

W czerwcu 1983 roku w Domu Artystów w Jerozolimie odbyło się spotkanie z Haimem Maorem, który właśnie wrócił z Polski, dokąd pojechał jako członek grupy artystów i pisarzy reprezentujących Państwo Izrael na obchodach czterdziestej rocznicy powstania w getcie warszawskim (uczestnicy zwiedzili obozy koncentracyjne oraz podążali śladami kultury żydowskiej). Twórca opowiadał o podróży oraz przybliżył własną biografię. Po wykładzie podszedł do niego mężczyzna, który przedstawił się jako pisarz - Dawid Grossman, i powiedział, że zbiera materiał do książki. Poprosił o wyrażenie zgody na wykorzystanie w niej historii, które Haim Maor opowiedział. W 1986 roku ukazało się hebrajskie wydanie powieści Grossmana, zatytułowanej עיין ערך: אהבה (czyt. ajen erech: ahava, czyli Patrz pod: Miłość), w której można odnaleźć wiele odniesień do dzieciństwa oraz rodzinnej historii Maora.

Numer 78446 pojawia się w pracach Haima Maora, począwszy od 1986 roku, w różnych formach i na różnych materiałach. Ów numer naziści wytatuowali na ramieniu ojca Haima, Dawida Moshkowitza, w 1942 roku, gdy trafil, wraz z rodziną, do obozu Auschwitz. Maora już w dzieciństwie intrygował tajemniczy tatuaż na przedramieniu ojca. „Na początku był numer. Niebieskie cyfry, wyblakłe, wytatuowane na piegowatej skórze, pokrytej brązowo-żółtymi plamami i siwiejącymi włosami pochylającymi się ku wysuszonej skórze, jak kolby kukurydzy na wietrze" ${ }^{\text {" }}$. Za wszelką cenę starał się dociec, co może on oznaczać. „Jako dziecko patrzyłem - wspominał - na muskularne ramię mojego ojca i wciąż recytowałem: siedem, osiem, cztery, cztery, sześć... najpierw niepewnym szeptem, jak osobiste zaklęcie: siedem, osiem, cztery, cztery, sześć, a potem na całe

${ }^{93}$ Por. Sh. Glotman: Mug Shots, Passport Photos, and Haim (Hi)Stories. In: Haim Maor. They are $\mathrm{Me} . . .$, s. $256-254$.

94 B. BARUtin: Haim Maor..., s. 133.

${ }^{95}$ H. MAOR: Zapomniane historie..., s. 127.

${ }^{96}$ Cyt. za: B. Barutin: Haim Maor..., s. 134. 
gardło, z żywiołową gestykulacją: siedem, osiem, cztery, cztery, sześć... powtarzałem i powtarzałem, wykrzykiwałem, sylabizując w urywanym rytmie. Kilka lat później byłem pochłonięty analizą lingwistyczno-kabalistyczną. Słownik, z którego korzystałem, definiował słowo tatuaż jako rysunek lub symbol wyryty w skórze, głównie poprzez nakłuwanie lub wypalanie skóry i rozprowadzanie $\mathrm{w}$ te rany szarpane nieścieralnego tuszu. Tatuaże są rozpowszechnione wśród niektórych plemion barbarzyńskich, żeglarzy i pilotów, którzy tatuują zwykle ramiona i piersi. Nie będziecie się tatuować (Księga Kapłańska 19, 28). Ojciec z pewnością nie był żeglarzem ani nie dorastał wśród dzikich plemion. - Tato, czy to prawda, że w ogóle nie chciałeś numeru, ale zostałeś zmuszony do jego posiadania? Ojciec milczał, jego twarz nie wyrażała emocji. Zmarszczki na jego czole i policzkach były niczym paski na zamieszczonej w słowniku, wytatuowanej twarzy australijskiego Aborygena. Byłem jak kabalista albo wizjoner patrzący na cyfry i gwiazdy, próbujący dotrzeć do istoty tego, co dla wzroku było niedostępne. Zaangażowałem się w odcyfrowywanie znaków i tajemnic, cyfr wyrytych w ciele, jakby były datami urodzin i śmierci na płycie nagrobnej albo szyfrem w zagadce. Bawiłem się liczbami jak numerolog, szukając ukrytych znaczeń. - Ojcze, czy przeżyłeś dzięki tajemniczej kombinacji w kolorze niebieskim, która obdarowała cię magiczną siłą - otwartym kontem w książeczce czekowej życia? Z czasem poznałem inne liczby: $\mathrm{z}$ dokumentu potwierdzającego tożsamość, z paszportu, książeczki wojskowej, numery telefonów w domu, w pracy, konta bankowego. Ale one nie zostały narzucone, tak jak siedem, osiem, cztery, cztery, sześć, związane z obrazem mojego ojca, jak przezroczyste i hermetyczne opakowanie celuloidowe" ${ }^{97}$. Chłopiec nadaremno starał się dociec znaczenia numeru, który przecież „weteranom obozowym mówi - zwrócił uwagę Primo Levi - wszystko: czas przybycia do obozu, transport, w skład którego wchodzili, i co za tym idzie, narodowośćc"98.

Dziadka Momika, bohatera pierwszej części znakomitej, nowatorskiej (biorąc pod uwagę sposób pisania o Zagładzie) powieści Dawida Grossmana Patrz pod: Miłość (polskie wydanie: 2008), Anszela Wassermana, przywieziono do rodziny Neumann niespodziewanie z kliniki dla psychicznie chorych w Bat Jam. Miał on na ręku, podobnie jak tata Momika, ciotka Itka i Bela, i wszyscy, którzy pochodzili „stamtąd”, numer. Momik „starał się rozszyfrować tajemny znak na ręku dziadka. Kiedyś próbował to zrobić ze znakami taty, Beli i ciotki Itki, i także mu się nie udało. Cyfry doprowadzały go do szału, bo nie zostały napisane piórem i nie schodziły po zamoczeniu ani zwilżeniu śliną. Momik próbował wszystkiego, kiedy mył dziadkowi ręce, ale numer pozostał. Dlatego Momik zaczął myśleć, że może nie jest napisany na zewnątrz, lecz od wewnątrz. To upewniło go jeszcze bardziej, że może naprawdę w dziadku ktoś siedzi. Może także w innych

\footnotetext{
97 H. Maor: Zapomniane historie..., s. 126.

98 P. Levi: Czy to jest człowiek. Przeł. H. Wiśniowska. Oświęcim-Warszawa 1996, s. 30.
} 
ludziach. W ten sposób te osoby wołają o pomoc. Momik łamał sobie głowę, próbując odgadnąć, co to znaczy. Zapisał numer dziadka w zeszycie obok numerów taty, Beli i Itki. Przymierzał do nich wszystkie działania rachunkowe. Potem przypadkiem uczyli się w szkole o gematrii. Momik oczywiście pojął to pierwszy. Po powrocie do domu od razu spróbował przełożyć cyfry na litery, ale to także się nie udało. Wyszły dziwaczne słowa, których nie rozumiał. Nie zniechęcił się jednak, bynajmniej. Pewnego razu, w środku nocy, przyszedł mu do głowy pomysł godny prawie Einsteina, bo przypomniał sobie, że istnieją rzeczy zwane sejfami. W sejfach bogaci ludzie chowają pieniądze i diamenty, a otwiera się je po przekręceniu siedmiu zamków zgodnie z pewnym sekretnym porządkiem. Możecie być pewni, że Momik spędził pół nocy na rachunkach i próbach. Następnego dnia po powrocie ze szkoły, kiedy przyprowadził dziadka do domu i dał mu obiad, usiadł naprzeciw i poważnym tonem zaczął wypowiadać rozmaite kombinacje cyfr, napisanych na ręku dziadka"

Obozowy numer, wytatuowany na przedramieniu ojca Haima Maora, 78446, stał się motywem obsesyjnie powracającym w kolejnych realizacjach artysty, przetwarzanym, począwszy od połowy lat 70., w przeróżnych konfiguracjach. I tak, w 1993 roku Maor wykonał pracę na pierwszy rzut oka abstrakcyjną. Ot, proste - wydawałoby się - ćwiczenie z opartu: 78446 (Color Blindness Test). Pointylistyczne plamy różnej wielkości w żywych kolorach: różowym, beżowym, granatowym, czerwonym, żółtym i błękitnym, przypominające charakterystyczne plansze testów na ślepotę barw (daltonizm). Tkanina zawieszona została na drążku, co stanowi odniesienie do parochetu. Uważny odbiorca odnajdzie w gmatwaninie owalnych form ukryte cyfry. Kolor skóry, plam na skórze - piegów i innych przebarwień, a także kolor tuszu, którym wykonano tatuaż, zostały przetransponowane i zakamuflowane $\mathrm{w}$ prostych, dekoracyjnych z pozoru kształtach. Atrakcyjna wizualnie, kolorowa praca może budzić skojarzenia ze słynnymi Spot Paintings Damiena Hirsta. „Ponieważ numer jest ukryty w kolorowych plamach, co przypomina test na daltonizm, to praca mówi o negowaniu Holocaustu albo - zwrócił uwagę Haim Maor - ignorowaniu Zagłady"100.

Na wystawie הספריה האסורה / The Forbidden Library (1993, The Center for Contemporary Art, The Hague / 1994, City Gallery, Kfar Saba / 2007, Massu'a Institute for The Study of The Holocaust, Tel Yitzhak) artysta zaprezentował między innymi pracę pt. מספר אור / Light Number (1993). W ciemnej sali, za eksponowaną na ścianie płytą z mosiądzu, znajdowało się źródło światła, które przenikało przez wydrążone (perforowane) w płycie otwory - cyfry 78446. Gdyby nie ów numer i kryjące się w nim odniesienie do rodzinnej historii, praca mogłaby zostać odczytana jako typowa realizacja z obszaru minimal artu. Świetlny numer odbijał się na twarzach oglądających, sprawiając, że stawali

\footnotetext{
99 D. Grossman: Patrz pod: Miłość. Przeł. M. Sommer. Warszawa 2008, s. 28-29.

${ }^{100}$ R. Jакивоwicz: Midrasz wizualny..., s. 10.
} 
się oni, mimowolnie, częścią instalacji. „Miedź jest jak lustro. Odbiorca, stojąc naprzeciw miedzianej tablicy, odbija się w niej i widzi swoją podobiznę, pojawiającą się, gdy - spostrzegł Maor - numer wyświetla się na jego czole"101. Intensywne światło oślepiało widzów, zmuszając ich do zamknięcia oczu i opuszczenia głowy. Cyfry powracały jednak, jak dręczące wspomnienia, w postaci powidoku. „I przez długi czas jeszcze, kiedy przyzwyczajenie z czasów wolności kazało mi spojrzeć na zegarek ręczny, rzeczywistość z ironią pokazywała mi wspominał Primo Levi - moje nowe nazwisko, numer, wyryty pod skórą niebieskimi znaczkami”"102. Tablica jest rozgrzana, co powoduje, że decydując się na dotknięcie jej, możemy się oparzyć. „Miedź jest materiałem związanym z alchemią i magią (»נחש נחושתן, czyli Nechusztan w Biblii), materiałem przewodzącym ciepło. Gdy dotykamy perforowanej tablicy, odczuwamy - mówił artysta ciepło spowodowane lampą umieszczoną z tyłu. Widz czuje coś jakby fizyczne pieczenie, co odpowiada hebrajskiemu powiedzeniu ממכוות אש" (czyt. mechwat esz), które znaczy: traumatyczne wydarzenia i doświadczenia, jakie przeszedłeś, "palą» twoją duszę i pozostawiają w tobie ślad. Jeśli »dotykasz« numeru (Shoa) nie będziesz mógł pozostać obojętny na jego znaczenie"103.

W 2008 roku powstała instalacja zatytułowana המזוודה של האב / Father's Suitcase (czyt. hamizwada shel aba, czyli „walizka ojca”). Jest to stara, zniszczona walizka, z którą ojciec artysty przybył do Izraela, znaleziona już po jego śmierci. „Rzeczy - pisała Barbara Shallcross - snują narracje o człowieku i jego śmierci i tym samym wywołują szczególne zderzenie pomiędzy teraźniejszością a przeszłością, pomiędzy zbiorowiskiem ocalałych przedmiotów a całością życia"104. Wewnątrz walizki znajduje się źródło światła. Wycięte otwory tworzą numer 78446.

„Naród żydowski z pewnością istnieje, ale różni się od wielu innych narodów tym, że jego linia życia nie przebiega - twierdzi Amos Oz - przez kwitnące ogrody ani zwycięstwa na polu walki, lecz przez książki”"105. W 2001 roku w moszawie Megadim odbyła się zorganizowana przez Miriam Brook-Cohen wystawa pt. Where is Dubnow?, poświęcona żydowskiemu historykowi Szymonowi Dubnowowi, autorowi dziesięciotomowej Historii narodu żydowskiego. Kuratorka chciała dociec, dlaczego nie czyta się już jego dzieła. Urodzonego na Białorusi Dubnowa można określić mianem historyka pronarodowego, ale nie syjonistycznego, popierającego uzyskanie praw oraz kulturalnej autonomii przez Żydów w państwach diaspory. „Nie uważał za możliwe ani stosowne, żeby transferować taką masę ludzi do Palestyny, by tam stworzyć ich własne państwo. Opowiadał się więc - pisał Shlomo Sand - za wydzieleniem autonomicznego

\footnotetext{
101 Tamże.

102 P. Levi: Czy to jest człowiek..., s. 30.

103 R. Jakubowicz: Midrasz wizualny..., s. 10.

104 B. Shallcross: Rzeczy i Zagłada. Kraków 2012, s. 8.

105 A. Oz: Do fanatyków..., s. 49.
} 
terytorium dla tego "wyjątkowego « żydowskiego narodu w miejscu, gdzie się znajdował. Dubnow odróżniał się jednak od większości zwolenników autonomii, którzy nie czuli się częścią obcej rasy w Europie i określali granice swojej tożsamości według norm i praktyk popularnej i tryskającej życiem wówczas kultury jidysz. Jego wrażliwość przednarodowa kazała mu zwrócić się pamięcią ku przeszłości, by wzmocnić tożsamość kolektywną, która jego zdaniem stała się problematyczna i krucha"106. Każdy z dziesięciu zaproszonych do projektu artystów dostał jeden tom Dubnowa. Haim Maor otrzymał ósmy - Koniec XVIII wieku, z którego stworzył pracę zatytułowaną המספר של אבא (דובנוב / Father's Number (Dubnow), przewiercając przez książkę otwory układające się w numer 78446. Druga połowa XVIII wieku to początek nowoczesności. „Koniec XVIII wieku to okres, kiedy zasymilowane żydowskie elity Europy Środkowej i Niemiec - spostrzegł Göran Rosenberg - zaczęły przyswajać ideały nacjonalistyczne i antyuniwersalistyczne” 107 . Zygmunt Bauman pisał: „Nowoczesna cywilizacja nie była wystarczającym warunkiem Zagłady, ale z całą pewnością była jej warunkiem koniecznym. Bez niej Zagłada byłaby nie do pomyślenia. To racjonalny świat nowoczesnej cywilizacji uczynił Zagładę wyobrażalną"108. Jego zdaniem „Zagłada jest efektem ubocznym nowoczesnego dążenia do precyzyjnie zaprojektowanego i całkowicie kontrolowanego świata, efektem, który pojawia się wówczas, gdy owo dążenie wymyka się spod kontroli”"109. Biurokratyczna machina, pozwalająca na skrupulatne planowanie, racjonalizowanie kosztów, wprowadzanie praktycznych, logistycznych rozwiązań, dostarczyła użytecznych narzędzi, które pozwoliły na masową eksterminację. „Techniczna kompetencja oddała się na zimno i bez jakichkolwiek przeszkód - mówił Alain Finkielkraut - na usługi szaleństwa niosącego śmierć, a Żydzi stali się jego ofiarami. Żydzi, czyli naród złączony z Historią Zachodu. Zbrodnia ta została dokonana na starodawnym plemieniu przez jeden z najwyżej rozwiniętych narodów Europy, plemieniu, którego tradycji Europa jest po części spadkobierczynią, który padał nieustannie ofiarą jej prześladowań i który w ogromnym stopniu przyczynił się do europejskiej modernizacji. Nasza cywilizacja została zamordowana bronią tejże samej cywilizacji: jakże odwrócić tę stronicę Historii?" ${ }^{110}$. Enzo Traverso sytuuje Zagładę w nieco szerszym kontekście. „Gilotyna, rzeźnia, fordowska fabryka i racjonalne zarządzanie wspólnie z rasizmem, eugeniką, masakrami kolonializmu i rzeziami I wojny światowej ukształtowały społeczne uniwersum i mentalny krajobraz, w których zaprojektowano i wprowadzono - pisał Traverso - w życie

106 Sh. SAND: Kiedy i jak wynaleziono naród żydowski..., s. 133-134.

107 G. Rosenberg: Kraj utracony..., s. 127.

${ }^{108}$ Z. Bauman: Nowoczesność i Zagłada. Przeł. T. Kunz. Kraków 2009, s. 48.

109 Tamże, s. 203.

110 A. Finkielkraut: Niewdzięczność. Rozmowa o naszych czasach (rozmawiał Antoine Robitaille). Przeł. S. KróLAK. Warszawa 2005, s. 62. 
"ostateczne rozwiązanie«"111. Jego zdaniem: „Między rzeziami podbijającego imperializmu a »ostatecznym rozwiązaniem « istnieją nie tylko odległe analogie czy »fenomenologiczne powinowactwo «. Mamy tu do czynienia $z$ historyczną ciągłością, która z Europy liberalnej czyni laboratorium XX-wiecznej przemocy, a z Auschwitz - autentyczny wytwór zachodniej cywilizacji”"12. Maor dokonał brutalnej ingerencji w dzieło Dubnowa, reprezentujące Księgę. „Numer umieszczony w książce pod postacią przebijających ją otworów skłania do refleksji, że nie jest on jedynie pamiątka pozostawioną przez więźniów Auschwitz, ale również - spostrzegła Barutin - pamiątka czynów nazistów, którzy pozostawili głęboką i bolesną ranę w historii Żydów symbolizowanej Księgą"113. Tom jest otwarty na stronie, na której zakreślone zostało zdanie: „Nawet w roku okropnej i ciężkiej wojny rząd w Warszawie nie zrezygnował z nakładania na Żydów nowych restrykcji i edyktów” 114 . Słowa: „wojna”, „Warszawa”, „restrykcje” i „edykty”, brzmią groźnie i złowieszczo, ponieważ natychmiast odsyłają do tragedii drugiej wojny światowej. Szymon Dubnow został zamordowany przez nazistów 8 grudnia 1941 roku w getcie ryskim i pochowany w masowej mogile.

„Aż do procesu [Adolfa Eichmanna - R.J.] pokolenie Palmachu i młodsze wyobrażało sobie Holokaust - zwróciła uwagę Shapira - jako coś, co zdarzyło się $\mathrm{w}$ innym miejscu, $\mathrm{w}$ innym czasie, innym ludziom"115. W dzieciństwie i młodości naziści byli dla Maora „potworami, a Żydzi szli na rzeź jak owce, Auschwitz był inną planetą, a Holocaust apokaliptycznym upadkiem kultury"116. Wyobrażał on sobie oprawców - podobnie jak Momik Dawida Grossmana - jako „nazistowską bestię" (Momik próbował wyhodować ją w komórce, by móc potem pokonać). Ten obraz zmienił się radykalnie po pierwszym przyjeździe do Polski, ale również za sprawą Suzanny, poznanej w 1986 roku Niemki, która przyjechała jako wolontariuszka do kibucu, gdzie mieszkał artysta ${ }^{117}$, usiłując przepracować mroczne historie swej rodziny. Suzanna była potem, przez ponad dziesięć lat, modelką Maora. Jej portrety, nawiązujące do niemieckiego malarstwa romantycznego, przedstawiały archetyp Niemki - obraz kobiecego ideału, na przykład (רוחי-ם) 1994 / A Fallen Angel or the Spirit of Ophelia (Vessel of Mer-Sea), 1994 - fotografia nawiązująca do obrazu Johna Everetta Millaisa.

W pracy zatytułowanej פני הגזע / Faces of Race (czyt. pnej hageza, czyli ,twarze rasy"), prezentowanej w Israel Museum w Jerozolimie, w 1988 roku, na wy-

${ }^{111}$ E. Traverso: Europejskie korzenie przemocy nazistowskiej. Przeł. A. Czarnacka. Warszawa 2011, s. 205.

112 Tamże, s. 208-209.

113 B. BARUtin: Haim Maor..., s. 139.

114 Tamże.

115 A. Shapira: Ben Gurion..., s. 235.

116 H. Maor (Moshкovitz): Sztuka i życie..., s. 129.

117 Realizacje Haima Maora odnoszące się do ruchu kibucowego pomijam w tym artykule. 
stawie פני הגזע והזיכרון / Faces of Race and Faces of Memory (czyt. panej hageza we hazikaron, czyli „twarze rasy i pamięci”), Maor zestawił czarno-białe fotografie swej rodziny, przyjaciół i sąsiadów ze zdjęciami Suzanny i jej rodziny. „W moich pracach portrety ludzi konfrontowane są - mówił - poprzez zestawianie ich i zamieszczenie naprzeciwko siebie, poprzez »katalogowanie« ich w świadomości widza jako »żydowskie» albo »aryjskie». Rysunki i fotografie pełnią rolę katalizatora przy wydobywaniu na powierzchnię uprzedzeń widza, który staje się "potencjalnym rasistą" "118. Artysta postawił tym samym odbiorców w bardzo dyskomfortowej sytuacji. Oglądając zawieszone na ścianach portrety, automatycznie klasyfikowali oni jedne twarze jako „żydowskie”, inne zaś jako „aryjskie", wpadając tym samym w pułapkę stereotypu nazistowskich kategorii rasy. „Była to niepokojąca symulacja, w której teraźniejszość przypomina przeszłość i w której bliscy mi ludzie - mówił Maor - wyglądają jak kryminaliści albo jak więźniowie obozu koncentracyjnego"119. Oddzielił on portrety kobiet od portretów mężczyzn, nawiązując w ten sposób do obozowych selekcji. Zdjęcia zostały zawieszone w sposób przypominający ekspozycję w bloku 11. w Państwowym Muzeum Auschwitz-Birkenau w Oświęcimiu. „Wydział, mieszczący się na parterze bloku 26. w Auschwitz, składał się z dwóch ciemni, trzeciego pokoju, gdzie ładowano filmy, biura i wielkiego pomieszczenia, gdzie robiono fotografie identyfikacyjne więźniów. To pomieszczenie było specjalnie wyposażone w aparat wielkoformatowy i obrotowe krzesło z półokrągłą podpórką pod głowę. Każdego więźnia fotografowano w trzech pozach: en face, w trzech czwartych profilem i profilem. Codziennie robiono - pisała Janina Struk - około czterdziestu lub pięćdziesięciu negatywów. W pierwszym okresie istnienia obozu filmy były łatwo dostępne i zamawiane przez Waltera albo z Agfy, albo z firmy pod nazwą »Opta« w Bydgoszczy. Odbitki, które robiono z tych negatywów, były dołączane do karty indeksowej o wymiarach 8 na 8 centymetrów z nazwiskiem, numerem, datą i miejscem urodzenia więźnia oraz miejscem, skąd został przywieziony. Indeks dzielił się na trzy kategorie: żywych, zmarłych lub przeniesionych do innego obozu. W okresie 1940-1941 ten niezwykle skuteczny system fotografowania nowo przybyłych więźniów, z których większość stanowili wtedy Polacy, był głównym zadaniem Erkennungsdienst. Później, w miarę, jak do obozu przybywało coraz więcej narodowości i grup rasowych, rejestrowani, oznaczani numerami obozowymi i fotografowani byli tylko ci, których zaliczano do kategorii więźniów politycznych. Nie obejmowało to tysięcy radzieckich więźniów wojennych, a następnie Cyganów i Żydów, których fotografowano tylko na specjalny rozkaz wydziału politycznego"120. Były to typowe zdjęcia „identyfikacyjne”, wykorzystane po raz pierwszy w XIX wieku, które „zaczęły być rozumiane i »od-

118 B. BARUTIN: Haim Maor..., s. 143.

119 R. JAkubowicz: Midrasz wizualny..., s. 10.

120 J. Struk: Holokaust $w$ fotografiach. Interpretacje dowodów. Przeł. A. Antosiewicz. Warszawa 2007, s. 146. 
czytywane« raczej jako dokumenty urzędowe niż pamiątki osobiste. Naziści doskonale to rozumieli. Możemy zapytać, czy odczłowieczony wizerunek więźniów - w pasiaku i z ogoloną głową - skonstruowano po to, by dopasować go do fizjonomiki typu »kryminalnego«. W wypadku ideologii przywiązującej obsesyjne znaczenie do wizerunków »typów« nie jest to może - spostrzegła Struk niedorzeczna sugestia"121.

„Ktoś mógłby potraktować zabieg Maora - pisał Dan Bar-On - jako zemstę wnuka. Naziści oślepili dziadka - wnuk-artysta wykorzystał w swojej sztuce wizerunek młodej Niemki. Niczym mściciel i oprawca, zdepersonalizował postać niemieckiej kobiety, transplantując jej wizerunek do izraelsko-żydowskiego kontekstu wyobrażeń Holocaustu. Jednak Niemka w pracach Maora jest osobą: ma na imię Suzanna. Co więcej, ma rodzinę i - rzecz zupełnie nieprawdopodobna Maor sięgnął do albumów jej zdjęć rodzinnych, może również zazdroszcząc jej albumów, których nie posiada jego rodzina. Stopniowo Suzanna odgrywała coraz ważniejszą rolę w próbach znalezienia przez Maora odpowiedzi na pytania: Kim byli ludzie, którzy zrobili to mojemu dziadkowi i ojcu? Jak mogą mieć takie miłe córki jak Suzanna? Czy mogą prowadzić podwójne życie?"122. Haim Maor wspominał moment, gdy oglądał albumy Suzanny: „Poprosiłem Suzannę o pokazanie mi albumów rodzinnych. Suzanna wniosła do pokoju zakurzone pudło wypełnione żółknącymi fotografiami, zabezpieczonymi w brązowych kopertach. - To fotografie moich dziadków i babć - powiedziała. Popatrzyłem na fotografie i zawstydzony zażartowałem o ich podobieństwie do twarzy żydowskich. Jedna z fotografii zmroziła mi krew: przystojny mężczyzna w mundurze oficerskim. - To mój dziadek, ojciec mojego ojca - powiedziała Suzanna, zmieszana. - Nie, nie był nazistą. To mundur oficera Wehrmachtu, z batalionu łączności. Nie, nikt z mojej rodziny nie był nazistą. Sprawdzałam to. Nic nie wiedzieli... Trzymałem wyblakłą fotografię, przyglądałem się jej z bliska. Czarna plama na piersi wyglądała jak swastyka. Odłożyłem zdjęcie i zamknąłem pudełko"123.

Milczenie jest jedną ze strategii wypierania ze świadomości tego, co bolesne, wstydliwe i kłopotliwe. Ma ono dwa oblicza: „nieme milczenie ofiar jako wyraz bezsilności oraz milczenie sprawców, będące w istocie - jak to ujął Piotr Forecki w odniesieniu do badań Aleidy Assmann - przemilczaniem oraz przejawem kontynuowania relacji władzy i podporządkowania, choć już w nowych warunkach"124. Gesine Schwan pisała o rodzinnej atmosferze milczenia charakteryzującej powojenne Niemcy, rodzącej międzypokoleniową przepaść (w gruncie rzeczy podobną do tej, jakiej doświadczało pokolenie ofiar). „Milczenie rodziców - zdaniem Schwan - dotyczyło przeszłości, a ściślej - własnego w niej udziału

121 Tamże, s. 263.

122 D. Bar-On, H. Maor: Od partykularyzmu do uniwersalizmu. Przeł. B. Juszczyк. „Pro Memoria” 2009, nr 2 (29), s. 145-146.

123 H. MAOR: Zapomniane historie..., s. 127.

124 P. Forecki: Po Jedwabnem. Anatomia pamięci funkcjonalnej. Warszawa 2018, s. 36. 
i osobistej winy. To nie było spokojne, opanowane milczenie mające chronić dziecko - kryło się za nim coś ciemnego, rodzącego strach i rozdrażnienie"125. Obowiązującą postawą wobec ofiar Zagłady stały się politycznie motywowane przemilczenia. „Urodzeni w Izraelu wstydzili się tego, że miliony ludzi »szły jak owce na rzeź«. Milczenie ocalonych przerodziło się - stwierdził Göran Rosenberg w tłumienie przeżyć, milczenie rdzennych Izraelczyków w pogardę"126. Własne strategie organizowania społecznej niepamięci wypracowały zarówno Niemcy, Francja, Stany Zjednoczone, jak i Polska, a także Izrael. „Ta cisza - lub represja miała wartość pragmatyczną. Ludzie musieli zakładać rodziny, budować domy, zdobywać zawody i wychowywać dzieci, a wspomnienia przeszłości, w tych pełnych determinacji wysiłkach odbudowania egzystencji, mogły - spostrzegła Anita Shapira - jedynie przeszkadzać" ${ }^{227}$. Chodziło o to, by tchnąć w doświadczone wojną społeczeństwa otuchę i wiarę. Szczególnie ważne było to w przypadku młodego państwa żydowskiego, walczącego o przetrwanie, które wyparło ze zbiorowej pamięci żydowską katastrofę XX stulecia. „Co roku w kwietniu Izrael obchodzi Dzień Pamięci Holokaustu i Bohaterstwa. Tragedię europejskich Żydów wspomina się i wykorzystuje w sferze stosunków ze społecznością międzynarodową. Jednakże w samym Izraelu - pisał Ari Shavit - nie przewiduje się miejsca dla pamięci o Holokauście. Od ocalałych oczekuje się, że nie będą rozpamiętywać swoich historii. Kilkanaście lat po Holokauście ta straszliwa katastrofa nie istnieje $\mathrm{w}$ lokalnych mediach ani w sztuce. Holokaust to tylko najniższy poziom, z którego wzniosło się syjonistyczne odrodzenie. Izraelskie continuum odrzuca traumę, klęskę, ból i potworne wspomnienia. Co więcej, w izraelskim continuum nie przewiduje się miejsca dla jednostki. Między innymi dlatego Holokaust pozostaje abstrakcyjny i pozbawiony kontekstu. Tak naprawdę wcale nie dotyczy ludzi, którzy żyją pośród nas. Przekaz jest jasny: siedźcie cicho, teraz budujemy naród. Nie zadawajcie zbędnych pytań. Nie użalajcie się nad sobą. Nie pozwalajcie sobie na wątpliwości, nie rozpaczajcie, nie bądźcie sentymentalnymi mięczakami, nie wywołujcie groźnych duchów. Nie czas teraz wspominać, czas zapomnieć. Musimy zmobilizować wszystkie siły i skupić się na przyszłości. Państwo żydowskie to oaza na rubieży, otoczona pustynią śmierci. Nie jest wystarczająco dojrzałe, aby zdobyć się na autoanalizę. Nie jest dość spokojne, aby spojrzeć z dystansu na swój własny dramat. Stoi przed nim o wiele za dużo wyzwań. Jest w nim za dużo bólu. Bez samodyscypliny, bez autowyparcia trudnej przeszłości i bez pewnej dozy okrucieństwa wszystko może się rozpaść" ${ }^{128}$. Dlaczego? „Pełna rzeczywistość Auschwitz była skryta za zasłoną niemożliwości:

125 G. Schwan: Polityczny sens przemilczanej winy. „Gazeta Wyborcza” z 31 sierpnia-1 września 2002 r. [dodatek: „Gazeta Świąteczna”], s. 19.

126 G. Rosenberg: Kraj utracony..., s. 271.

127 A. Shapira: Historia Izraela..., s. 307.

128 A. Shavit: Moja Ziemia Obiecana..., s. 186-187. 
nie dawała się - jak to określiła Idith Zertal - wypowiedzieć i opisać"129. Ocalali skrywali swoje przeżycia z czasów Zagłady. Nie tylko dlatego, że były one zbyt traumatyczne, by je „wypowiedzieć i opisać”, ale także dlatego, że w Izraelu, kraju, w którym znaleźli schronienie, nie chciano wysłuchać ich świadectwa. Barierą bywał również język. Rodzice Haima Maora posługiwali się językiem hebrajskim „w sposób niedoskonały i niepoprawny”, w związku z czym czuli, że "nie mają odpowiednich słów, żeby móc wyrazić i opisać przerażające przeżycia, których doświadczyli”, co powodowało, że decydowali się „działać w ciszy”130. "Wielu ocalałych uważało, że opowiedzenie wojennej historii to ich patriotyczna powinność; wielu mówiło, że w powojennych miesiącach czuli się, jakby byli ostatnimi żyjącymi Żydami, jedynymi, którzy wiedzą, co się stało z ich społecznościami. Każdy miał moralny i historyczny obowiązek zachować pamięć o pozostałych. Próba opowiedzenia o swoich losach - pisał Tom Segev - świadczyła również o głębokiej potrzebie podzielenia się z innymi tym przytłaczającym ciężarem emocjonalnym. Ocaleńcy odkryli jednak, że ludzie nie zawsze chcą - albo nie mogą - ich słuchać"131.

Dla głosu ocalałych zaraz po wojnie nie było miejsca w publicznej debacie. „Od chwili powstania państwa Izrael Zagłada i miliony śmierci były stale obecne w mowie i milczeniu narodu, w życiu i koszmarach setek tysięcy ocalonych, a także w krzywdzącej - pisała Idith Zertal - nieobecności ofiar"132. Izraelskie społeczeństwo musiało się zmagać z wieloma zagrożeniami, które wymagały często poświęcenia życia, co skłaniało do odrzucenia słabości i propagowania witalności oraz siły. Stąd niechęć do ocalałych, którzy zostali naznaczeni poniżeniem, strachem i śmiercią, i którzy odstawali przez to od obrazu "nowego Hebrajczyka”, reprezentując rodzącą negatywne skojarzenia figurę „starego Żyda”. „W ciągu pierwszych dziesięciu lat swego istnienia, czyli w kulminacyjnym okresie rewolucji, państwo Izrael cierpiało - pisała Zertal na selektywną amnezję, bowiem niektóre rozdziały historii żydowskiej mogły stanąć na przeszkodzie wysiłkom państwowotwórczym i burzyć oficjalną narrację o potędze i odrodzeniu"133. Dlatego dla ofiar Zagłady, dla trzystu tysięcy jej świadków szukających domu w nowej ojczyźnie, czyli tzw. ostatka, zabrakło miejsca $\mathrm{w}$ imaginarium oraz polu symbolicznym formującego się społeczeństwa. „Choć odmienili tkankę społeczną kraju, byli jedynie - jak to określiła Zertal - »obecnymi-nieobecnymi«. Był to czas bohaterów, a nie ofiar. O Zagładzie wspominano sporadycznie"134.

\footnotetext{
129 I. Zertal: Naród i śmierć..., s. 100.

130 R. Jakubowicz: Midrasz wizualny..., s. 9.

131 T. Segev: Siódmy milion..., s. 149.

132 I. Zertal: Naród i śmierć..., s. 15.

133 Tamże, s. 163.

134 Tamże, s. 164.
} 
Nie przyjmowano do wiadomości rozmiaru tragedii, jaka dotknęła naród żydowski, odrzucano pamięć o Szoa, wręcz ją kwestionowano ${ }^{135}$. „Pogarda, jaką wielu członków jiszuwu żywiło dla diaspory, nie zniknęła podczas Zagłady a raczej nawet się pogłębiła. Po wojnie natomiast, pełna wyższości, zrodzona z żalu i wstydu relacja jiszuwu do ocalałych była przyczyną tej wielkiej ciszy, jaka otaczała Zagładę przez całe lata pięćdziesiąte. W tamtych czasach Izraelczycy odmawiali rozmowy, a nawet myślenia o Zagładzie, niemal aż do granic - pisał Tom Segev - jej zaprzeczania"136. Zaczęto nawet obwiniać samych ocalałych, co skutkowało tym, że ofiary zamykały się w sobie, w poczuciu winy i wstydu. „Zagładę zaczęto postrzegać jako klęskę Żydów. Obwiniano jej ofiary, że pozwoliły się hitlerowcom mordować, nie walcząc o życie, o prawo, by "zginąć z honorem«. Z czasem taka postawa stała się rodzajem politycznego i psychologicznego widma, nawiedzającego państwo Izrael i uosabiającego pogardę i hańbę, pychę i strach, niesprawiedliwość i szaleństwo"137. Śmierć ofiar Holokaustu przeciwstawiano śmierci bojowników getta oraz tych, którzy w Palestynie polegli za ojczyznę. Śmierć w upodleniu, która stała się udziałem ofiar, była wartościowana negatywnie, nie przystawała do „pięknej śmierci” w Erec Israel. „Ustanowiono zatem miarę: śmierć większości prześladowanych Żydów, którzy, zdaniem syjonistów, poddawali się swemu losowi całkowicie biernie, była śmiercią "nędzną" lub co najmniej "pozbawioną piękna« [...]. Natomiast śmierć powstańców, którzy stawili opór w getcie, była "piękną śmiercią", dzięki której zyskiwali oni »życie wieczne «"138. Śmierć w Zagładzie, z wyjątkiem śmierci nielicznych żydowskich bojowników, była - jak to określił Jean-François Lyotard - „śmiercią gorszą niż śmierć"139.

/ A Message from Auschwitz-Birkenau To Tel Hai (czyt. tiszdoret miAuschwitz-Birkenau leTel Chaj), czyli wiadomość wysłana z „Doliny Śmierci” do „Wzgórza Życia” ${ }^{140}$, to instalacja zrealizowana w 1983 roku, w ramach projektu Tel Hai '83: Contemporary Art Meeting w Tel Chaj. Tel Chaj ${ }^{141}$ (תל חל חל to osada żydowska w Górnej Galilei (obecnie część kibucu Kfar Giladi - כפר גלעדי), założona w 1905 roku w Palestynie, zniszczona 1 marca 1920 roku w wyniku ataku libańskich Beduinów. Obrona Tel Chaj dała początek

135 Tamże, s. 164-165.

136 T. Segev: Siódmy milion..., s. 478.

137 Tamże, s. 106.

138 I. Zertal: Naród i śmierć..., s. 50.

139 „Ci, którzy umierają za coś, co ich przekracza, za ojczyznę, za ideał państwowy lub narodowy, na zawsze zyskują sławę i życie wieczne. Śmierć w Zagładzie, a zwłaszcza śmierć w Auschwitz, była, zdaniem Lyotarda "przeciwieństwem pięknej śmierci«, była »śmiercią gorszą niż śmierć«" (tamże).

140 „Tel Chaj” (תל חי) to w języku hebrajskim „Wzgórze Życia”.

${ }^{141}$ W polskiej literaturze funkcjonują pisownie: „Tel Hai”, „Tel Chai” oraz „Tel Chaj”. Ta ostatnia forma zapisu wydaje się zgodna z zasadami transkrypcji, dlatego posługuję się nazwą „Tel Chaj”, pozostawiając jednocześnie różne wersje zapisu w przytoczonych cytatach. 
bohaterskiemu mitowi. Beduini szukali w osadzie ukrywających się Francuzów. Ówczesne wydarzenia tak opisał Konstanty Gebert: „Mieszkańcy zgodzili się na przeszukanie osiedla; tego dnia Francuzów tam nie było. Podczas gdy Arabowie przeprowadzali rewizję, jeden $\mathrm{z}$ osadników strzałem w powietrze ściągnął posiłki z pobliskiego Kfar Giladi. Przybyło dziesięciu członków samoobrony pod dowództwem Josefa Trumpeldora, twórcy Legionu Żydowskiego. W całkowicie niewyjaśnionych okolicznościach między samoobroną a Arabami doszło do starcia, w którym zginęło sześciu Żydów (w tym dwie kobiety) i pięciu Arabów. Dwunastą ofiarą był sam Trumpeldor zmarły pod wieczór na skutek odniesionych ran. Po starciu wrogość Arabów wzrosła, zaś siły samoobrony poważnie osłabione, nie mogły już zagwarantować obu osiedlom bezpieczeństwa; wnet zostały ewakuowane. Choć starcie najprawdopodobniej było wynikiem nieporozumienia (jeden z pierwszych raportów żydowskich mówi o »błędach po obu stronach«), to $\mathrm{w}$ świetle późniejszego, dramatycznego zaostrzenia żydowsko-arabskiego konfliktu, Tel Hai urosło do rangi symbolicznej pierwszej bitwy w niekończącej się wojnie. Przypisane twórcy Legionu ostatnie słowa: „Nie szkodzi, dobrze jest umierać za swoją ojczyznę" są niemal na pewno literacką fikcją. Ale mit Trumpeldora i obrony Tel Hai rósł: założona przez syjonistów-rewizjonistów w latach trzydziestych XX w. organizacja młodzieżowa Betar (Brit Josef Trumpeldor, czyli Przymierze im. Josefa Trumpeldora; nazwa nawiązuje także do Betaru, żydowskiej fortecy z czasów wojny z Rzymianami w 70 r.) nosić będzie jego imię"142. Haim Maor, gdy został zaproszony do wzięcia udziału w wystawie w Tel Chaj, zwrócił uwagę, że główny budynek przypomina kształtem Bramę Śmierci Birkenau. W obiekcie trwał wówczas remont, w związku z czym korytarze były puste, pozbawione prądu i wentylacji. תשדורת מאושוויץ-בירקנאו לתל-חי to realizacja typu site-specific. Artysta postanowił zaanektować cały budynek, łącząc wnętrza zielonym kablem elektrycznym. W ten sposób zamienił go w wielką instalację. Widzowie wchodzili, mijali puste pomieszczenia (drogę wskazywały plansze informacyjne z czerwonymi kierunkowskazami), schodzili po schodach, szli dalej korytarzem, kierując się - w całkowitej ciemności - do znajdującego się na jego końcu bunkra. Tam na suficie zamontowany był niedziałający jeszcze system wentylacyjny (zastany element architektoniczny), przypominający wielkiego ptaka lub krzyż. Pod nim artysta umieścił czarne tory kolejowe, które były metaforą transportów do obozów śmierci, zakończone tzw. kozłem oporowym (po obu jego bokach stały dwa podobne), gdzie spoczywała z kolei czarna metalowa rzeźba przypominająca kruka (motyw kruka często pojawiał się we wczesnych pracach Maora), orła lub nazistowską gapę. Na ścianie wisiała czarna forma wycięta ze sklejki - hybrydowe połączenie zabudowań Tel Chaj i Bramy Śmierci w Birkenau - bramy, która, „jako przejście do "piekła« stała się - zwróciła uwagę Agnieszka Pajączkowska - współcześnie jedyną [!] z najpowszechniejszych klisz

${ }^{142}$ K. Gebert: Miejsce pod słońcem. Wojny Izraela. Warszawa 2008, s. 61. 
Holokaustu”143. Haim Maor pomalował na czarno również trzy drabiny ewakuacyjne znajdujące się na bocznej ścianie, prowadzące do trzech okien, zaprojektowanych tak, by można - w razie czego - uciec z bunkra. Wewnątrz było duszno i gorąco. Światło z dwóch reflektorów, podobnych do tych, które znajdują się na wieżach strażniczych, skierowano na czarną formę przypominającą Bramę Śmierci Birkenau. Warto zwrócić uwagę na dialog wizualny: trzy czarne kozły oporowe kontra trzy czarne drabiny. Dodatkowo, w zawieszonej na ścianie formie widać było trzy wycięte okna wieży strażniczej. „Ludzie wchodzili do schronu wstrzymując oddech. Milczeli. Rozumieli, że pomieszczenie, mające dawać schronienie, stawało się śmiertelną pułapką - Birkenau, obrazem śmierci. Byli zdezorientowani i zadawali sobie pytanie, czy to budynek Birkenau, czy Tel Chaj. Nie trzeba wielkiej wyobraźni, żeby zrozumieć, że kolejka ludzi, którzy czekali w korytarzu, żeby wejść do schronu przypominała - mówił artysta - kolejkę Żydów przy wejściu do komory gazowej. Także tutaj ludzie szli w nieznane, bez zbędnych pytań"144. Po lewej stronie znajdowały się żelazne drzwi, które prowadziły do wyjścia z budynku. Wychodzący trafiali na mały pokój, w którym był prysznic - element zastany. W tym czasie „świadomość Holokaustu stała się częścią psychiki młodszego pokolenia. Ich wiedza o tym, co spotkało lud żydowski w Europie podczas II wojny światowej doprowadziła do dwóch wniosków: że arabskie groźby wyrzucenia Żydów do morza były realne i że ich obowiązkiem jest - pisała Anita Shapira - bronić narodu, zapobiec powtórce masowej eksterminacji i degradacji godności ludzkiej ludu żydowskiego"145.

Śmierć Josefa Trumpeldora oraz przypisywane mu słowa: „To nic! Słodko jest umierać za ojczyznę", ostatnie rzekomo słowa wypowiedziane do przyjaciół tuż przed zgonem, stały się jakże potrzebnym i czytelnym w latach 20. symbolem. Stały się początkiem mitu, swoistym drogowskazem dla młodych osadników. Krótko po klęsce Włodzimierz Żabotyński pisał: „Gdy triumfuje wola, wydarzenia się nie liczą. Dopóki wola trwa, gorzki żal zamienia się w słodycz. Wola jest górą życia (Tel Chaj)"146. Później Żabotyński za śmierć Trumpeldora i jego towarzyszy obwiniał liderów jiszuwu, którzy jego zdaniem porzucili garstkę młodych ludzi na małej farmie. „Mityczna opowieść o Tel Chaj i śmierci jej bohatera służyła, z jednej strony, jako wzór dla młodych bojowników getta, z drugiej zaś podobnie jak mit Masady - była przeciwstawiana - pisała Idith Zertal - śmierci żydowskich mas podczas Zagłady"147. Mieszkańcy Palestyny nie byli sobie w stanie wyobrazić warunków życia w gettach i obozach, dlatego też nie potrafili współczuć ofiarom Holokaustu. Śmierć Trumpeldora była wzorem „pięknej śmierci”, ofiary poniesionej z bronią w ręku, w obronie ojczyzny. „Ważna

\footnotetext{
143 A. PająCZкowsкa: Brama. W: Ślady Holokaustu..., s. 55.

144 R. JakUbowicz: Midrasz wizualny..., s. 8.

145 A. Shapira: Historia Izraela..., s. 366.

${ }^{146}$ Cyt. za: I. Zertal: Naród i śmierć..., s. 25.

147 Tamże, s. 17
} 
była nie indywidualna i przypadkowa śmierć Trumpeldora, ale jej interpretacja dokonana przez tych, których pozostawił. Liczy się zatem pamięć o zmarłych konstruowana i rekonstruowana nieustannie przez żywych i - na koniec - sposób, w jaki żywi wykorzystują ową pamięć dla własnych celów"148. Bitwa o Tel Chaj była przypadkowa i niepotrzebna, co więcej skończyła się całkowitą klęską. Nie przeszkodziło to jednak w tworzeniu mitu. Nadanie temu wydarzeniu mitycznego wymiaru nie wynikało tylko z potrzeby ukrycia porażki i kompensacji poczucia słabości. Zdaniem Idith Zertal „należy dostrzec w tym zamysł dużo głębszy, a mianowicie próbę wymazania doświadczenia śmierci, wyniesienia ofiar ponad ich historyczną śmierć i przeistoczenia ich w symbolicznych "umarłych «, w wiecznie żywych, w nieśmiertelną "górę życia» (tel chaj), by przywołać słowa Żabotyńskiego. Żywi umarli włączeni przez swą śmierć w wieczny cykl życia i natury. Symboliczne unieważnienie śmierci ma życiowe znaczenie dla rodzącego się społeczeństwa, które bije się o swe ziemie i poprzez kolejne »beznadziejne " walki aż do chwili "gdy niemożliwe stanie się możliwym", wpaja swym synom etos władzy i prawo miecza"149. Tel Chaj, będące grobem sześciu poległych w feralnej i chaotycznej bitwie, stało się przedmiotem najwyższej czci, kultu siły i bohaterstwa, ponieważ budowanie narracji, w której niewielka grupa obrońców ściera się z przeważającymi siłami wroga, odpowiadało na zapotrzebowanie ruchu syjonistycznego, stającego w obliczu coraz częstszych potyczek z Arabami. „To właśnie w Tel Chaj - pisała Zertal - wytworzyła się więź pomiędzy ziemią i krwią, ziemią i potem tych, którzy ją uprawiają, czyli trwały kult żołnierza-chłopa stojącego na straży granic ojczyzny i poświęcającego się dla niej - podatny grunt dla rozwoju narodowej mitologii w Europie z początków XX wieku. Kult ten pozostawał w sprzeczności z obronną, wrogą krwi i sile retoryką opisu wydarzeń. W wymiarze powierzchownym mit Tel Chaj określić było można jako mit z gruntu obronny, jednak w wymiarze głębszym niósł on przekaz o sile i podboju, o zdobywaniu ziemi, której granice wyznaczyć i legitymizować może jedynie krew wojowników. Krew poległych z Tel Chaj niejako sankcjonowała sakralizację i podbój gór Galilei”"150, opisany później między innymi przez Ilana Pappé ${ }^{151}$. Ponieważ zgodnie z mitem Tel Chaj „nie rezygnuje się z tego, co się zbudowało"152.

Haim Maor, realizując swój projekt w Tel Chaj, dokonał zadośćuczynienia, swoistej rehabilitacji ofiar Zagłady, przemieniając ich „nędzną śmierć” w śmierć „piękną", tak wysławianą przez hebrajskojęzycznych syjonistycznych poetów. Symbolicznie zwrócił im odebraną godność. Mówił: „[...] stworzyłem konfrontacje $\mathrm{z}$ normatywnym heroizmem, $\mathrm{z}$ tym, jak postrzegano heroizm $\mathrm{w}$ ówczes-

\footnotetext{
148 Tamże, s. 26.

149 Tamże, s. 38-39.

150 Tamże, s. 45.

151 Por. I. PAppé: Czystki etniczne...

152 A. Shapira: Historia Izraela..., s. 431.
} 
nym społeczeństwie izraelskim: bohater to ktoś, kto zginął w walce z Arabami. Na przykład ktoś taki jak Josef Trumpeldor i jego towarzysze, którzy osiedlili się w Tel Chaj w czasach wczesnego syjonizmu. Tymczasem ja za pośrednictwem tej pracy pokazałem, że także przetrwanie Żydów w obozie koncentracyjnym w czasie Shoa było heroizmem. W 1983 roku (pamiętaj, że trwała wówczas Wojna Libańska [operacja o kryptonimie „Pokój dla Galilei”, lata 1982-1985 R.J.], bardzo blisko od Tel Chaj) nie była to powszechnie akceptowana opinia. Dziś, kiedy mówimy o ocalałych z Zagłady, mówimy o przetrwaniu jako o rodzaju heroizmu. Ten, kto zdołał przeżyć dwa lata w Auschwitz-Birkenau, tak jak mój ojciec, jest bohaterem"153. Pogardzana przez lata śmierć ofiar Zagłady, śmierć bez broni w ręku, w strachu i poniżeniu, stała się wreszcie równie znacząca jak śmierć pierwszych osadników, poniesiona w walce z Arabami. Arabami, którzy w izraelskich książkach dla młodzieży przedstawiani byli jako postaci okrutne, żądne krwi i tchórzliwe. „Jest on [Arab - R.J.] odważny wobec bezbronnych kobiet i dzieci, ucieka natomiast przed prawdziwymi mężczyznami i mrokiem nocy. Częstuje kawą i tą samą, podstępną dłonią wbija nóż w plecy. Arab - zapamiętał Göran Rosenberg z kilku lat dzieciństwa spędzonego w Izraelu - to »mentalność« a nie człowiek. W najważniejszej być może dla ruchu syjonistycznego legendarnej historii bohaterskiej śmierci jednorękiego Josefa Trumpeldora w bitwie o Tel Chaj w 1909 roku, atakujący Arabowie byli anonimowymi, mrocznymi postaciami pozbawionymi imion i znaczenia"154.

Symboliczna zamiana Tel Chaj w Birkenau pociąga też inne implikacje. Przenosi ona Zagładę z bezpiecznego wymiaru czegoś, co dokonało się dawno temu w odległej Europie, w izraelską rzeczywistość, sugerując, że zagrożenie cały czas jest realne, bezpieczne schronienie zaś może stać się w jednej chwili, niepostrzeżenie śmiertelną pułapką. „Holokaust pozostaje zarówno ludzki jak i obcy. Najgorszą postawą, jaką możemy przyjąć, jest - pisał Geoffrey Hartmann przekonywanie samych siebie, że Holokaust nie może się wydarzyć po raz kolejny lub że jest czymś, co zdarzyło się już wcześniej - że Holokaust był jedną z wielu katastrof"155. André Glucksmann zwrócił uwagę, że antysemityzm jest odwieczną namiętnością: „Zadziwiająca umiejętność skupiania jednostkowych majaczeń i heterogenicznych złości wokół zbiorowej, linczującej furii zdolnej tworzyć najdoskonalszą więź społeczną - to cecha, żadne to odkrycie, nienawiści do Żydów. Ta niszczycielska namiętność przemierza tysiąclecia, stroi się zgodnie z obowiązującą modą, nieustannie odradza się z popiołów rozmaitych fantazmatów, które zdają się stanowić dla niej usprawiedliwienie. Wydawała się chrześcijańska, a swe apogeum osiąga, gdy Europa się zdechrystianizowała. Wydawało się, że wygasła po Hitlerze, a ona - patrzcie no tylko - staje się globalna.

153 R. Jakuвowicz: Midrasz wizualny ..., s. 8.

${ }^{154}$ G. Rosenberg: Kraj utracony..., s. 39.

155 G. Hartmann: Bitburg. Przeł. T. Łysak. „Literatura na Świecie” 2004, nr 1-2 (390-391), s. 335 . 
Liczymy na to, że wycofa się na upatrzone pozycje, gdzieś w mroki obskurantyzmu i ksenofobii, a tymczasem w wieczornych wiadomościach znów głośno o Jerozolimie i okolicach, a każdy z mieszkańców globu - pisał Glucksmann - czuje się w obowiązku opowiedzieć się po którejś ze stron, wybrać jeden z obozów”156. Trzeba więc zapytać: „Czy należy przypuszczać, że nienawiść do Żyda pojawia się dziś na nowo w niezmienionej, odwiecznej formie po okresie utajenia, który nastąpił po otwarciu obozów śmierci? Powiedzmy raczej, że z epoki na epokę pradawna nienawiść przyobleka się $\mathrm{w}$ coraz to nowe szaty, które na pewien czas czynią ją nierozpoznawalną"157. Obrazoburcze nałożenie wizerunku Bramy Śmierci Birkenau na przypominający ją do złudzenia kontur zabudowań Tel Chaj, czyli wyeksponowanie formy-konturu Tel Chaj-Birkenau, jest koszmarnym powidokiem wypieranej przeszłości i materializacją lęku o przyszłość państwa żydowskiego. Ikona Zagłady Żydów została połączona z ikoną walki narodu żydowskiego o ojczyznę. Tel Chaj to, rzecz jasna, nie Birkenau. Jednak nie pozwala uwolnić się od natręctwa fatalnych skojarzeń wizualnych. Obraz Birkenau, zdaje się mówić artysta, nosimy w sobie, będzie już z nami wszędzie, niezależnie od tego, jak mocno staramy się zapomnieć. Na zawsze pozostanie on cieniem nowego, silnego i dumnego Hebrajczyka, również potomka syjonistycznych pionierów, chaluców z pierwszych aliji. Problem ten porusza także praca Haima Maora z 2010 roku zatytułowana ( Camp (According to Otte Wallish) (czyt. machane, al pi Otte Walisch, czyli „obóz według Otto Walischa”). Obraz jest wierną, malarską reprodukcją rysunku słynnego izraelskiego ilustratora Otto Walischa (אוטה וליש), który zaprojektował wiele spośród najbardziej znanych symboli Państwa Izrael. Rysunek pochodzi z zeszytu pt. ארץ ישראל (czyt. erec israel) z lat 1937/1938, czyli okresu חומה ומגדל (czyt. choma umigdal, czyli „mur i wieża”). Kibuce, zgodnie $\mathrm{z}$ ideą Wall and Tower Shlomo Gura i Yohanana Ratnera, budowano z prefabrykatów dowożonych na miejsce ciężarówkami. Składały się one $\mathrm{z}$ wieży obserwacyjnej i kilku drewnianych baraków, otoczonych obronnym murem. Wznoszono je w ciągu jednego dnia, wykorzystując stare prawo otomańskie zakazujące wyburzania zadaszonych budowli, działając tym samym metodą faktów dokonanych. „Ich podstawowym zadaniem była - stwierdził Artur Jasiński - ekspansja terytorialna - tworzyły zręby sieci osiedleńczej, poszerzającej przyszłe granice państwa Izrael. Stały się swoistymi »machinami inwazji«, a ich spektakularna forma dominowała nad podbitą przestrzenią"158. Łudzące podobieństwo tej całkowicie podporządkowanej funkcjom militarnym i kolonizatorskim architektury kibucowej z drugiej połowy lat 30. do wizualności nazistowskich obozów koncentracyjnych (co dodatkowo sugeruje tytuł obrazu Maora) jest jed-

\footnotetext{
156 A. Glucksmann: Rozprawa o nienawiści. Przeł. W. Prażuch. Warszawa 2008, s. 79-80.

157 Tamże, s. 83.

158 A. Jasıński: Architektura i urbanistyka Izraela. Kraków 2016, s. 38.
} 
noznaczne i może być - zwłaszcza w przypadku odbiorcy, który nie zna okresu חומה ומגדל - zwodnicze. Wall and Tower to projekt historyczny, który trudno jednak - biorąc pod uwagę specyfikę współczesnej urbanistyki Izraela - zamknąć w czasie przeszłym dokonanym. „Wieża i mur - motyw charakterystyczny dla zmilitaryzowanych placówek osiedleńczych - stał się - stwierdził Jasiński - wzorem widocznym w całym szeregu izraelskich budowli cywilnych: od prywatnych rezydencji jego dwóch premierów poczynając, na sylwetach większości współczesnych osiedli kończąc"159. Zagłada, zdaniem Görana Rosenberga, wypielęgnowała w Izraelu „rosnące poczucie istnienia w oblężonej twierdzy lub - dlaczego nie? - w otoczonym zasiekami z drutu kolczastego obozie" 160 .

„Fakt, że walka o niezależne żydowskie państwo Izrael została wygrana już trzy lata po zakończeniu wojny w Europie i była prowadzona po części przez ocalałych, oznaczał, że od początku istniała »ogromna więź emocjonalna« między Holokaustem a Izraelem. Ale pytanie, jak to możliwe, że tyle milionów poszło na śmierć »jak barany do rzeźni«, budziło uczucia gniewu, wstydu i rozczarowania, które nie pasowały - stwierdziła Janina Struk - do wizerunku nowego państwa" ${ }^{\prime 161}$. Ocaleni musieli nie tylko samotnie radzić sobie z traumą i oskarżeniami o tchórzostwo, ale również tłumić narastające poczucie winy. "Choć większość ocalałych zawdzięczała życie przypadkowi, a nie poświęceniu kogoś innego, obwiniali się za to, że przeżyli. Uczucie to często kryło - stwierdził Segev - bezsilność ofiar. Pozwalało im myśleć, że mieli wybór - i wybrali przeżycie”162. Traktowali własne ocalenie jako coś, co nie powinno się zdarzyć, mieli ciągłe poczucie, że uratowali się czyimś kosztem (Judith Butler zwróciła uwagę, że niektóre fragmenty książki Prima Leviego Pogrążeni i ocaleni „sprawiają takie wrażenie, jak gdyby autor uważał, że udało mu się przeżyć kosztem innych; że z powodu własnego postępowania czy własnej bierności jest winny śmierci innych i nie może znieść tego, że ocalał, podczas gdy innym się to nie udało”, w związku z czym "postrzegał swoje ocalenie jako nieuprawnioną uzurpację"163). „Już samo bycie ocalonym jest bowiem błędem. Błędem - pisała Zertal - trwania przy życiu tam, gdzie powinno się być umarłym. Jedynie śmierć własna, pozwalająca dołączyć - choćby poniewczasie - do umarłych, może uwolnić ocalonych od poczucia winy"164. Ci, którzy przeżyli, zostali odrzuceni, ponieważ obecność ludzi, którzy przetrwali katastrofę, była trudna dla tych, którzy nie mieli takich doświadczeń; burzyła ich kruche poczucie bezpieczeństwa, wzmagała lęk - w tamtych niepewnych czasach - przed podobną ka-

159 Tamże, s. 194.

160 G. Rosenberg: Kraj utracony..., s. 281.

161 J. STRUK: Holokaust $w$ fotografiach..., s. 218.

162 T. SEgEv: Siódmy milion..., s. 153.

163 J. Butler: Na rozdrożu. Żydowskość i krytyka syjonizmu. Przeł. M. Filipczuk. Warszawa 2014, s. 307-308.

164 I. Zertal: Naród i śmierć..., s. 94. 
tastrofą, mogącą w każdej chwili nadejść. Ocalali w oczach reszty społeczeństwa ujawnili „skrywaną, barbarzyńską stronę cywilizacji, mroczny rewers wartości i ideałów nowoczesnego społeczeństwa. To, co ocaleni z obozów reżimów totalitarnych widzieli i wiedzieli, tego żaden człowiek - pisała Zertal - nie powinien nigdy widzieć ani wiedzieć" 165 . Obawiano się kontaktu z ocalałymi, obawiano się ich psychicznego i fizycznego okaleczenia, ich cierpienia oraz strachu (tego problemu dotyka właśnie przywołana już praca Haima Maora z 2010 roku, pt. / Marked Words, pokazująca, że nawet „kacetnicy” bali się innych „kacetników”, bywali wobec nich podejrzliwi i pełni uprzedzeń, ponieważ przecież mogli oni okazać się na przykład „meszugenerami” - „wariatami”). „Ocaleli z Zagłady pochodzili - jak to określił Segev - z innego świata i do końca swoich dni pozostawali jego więźniami”166. Byli przeciwieństwem propagowanego przez syjonizm wzorca urodzonego i dorastającego w Izraelu dumnego Sabry. „W pewnym momencie ocalałych z Zagłady zaczęto nazywać sabon - »mydło«. Nie jest całkiem pewne, kiedy to określenie pojawiło się po raz pierwszy, niewątpliwie jednak było powszechnie używane. Odzwierciedlało przekonanie, że hitlerowcy wykorzystywali ciała zamordowanych Żydów do produkcji mydła; powtarzano je nieustannie, aż stało się pewnikiem; mówiono o tym w Knesecie, pisano w podręcznikach i literaturze izraelskiej (»Na półce sklepowej, opakowana w żółty papier z narysowanymi liśćmi oliwki, leży rodzina Rabinowiczów«, napisał Joram Kaniuk w »Adamie, synu psa«). Trudno chyba - ocenił Segev - o lepsze wyrażenie pogardy, jaką rdzenni Izraelczycy czuli wobec ocalałych"167. Niektórzy więc, ci, którzy nie potrafili wyprzeć wojennych doświadczeń z Europy, wybierali samobójstwo. „Jest wysoce prawdopodobne, że owo wielopoziomowe wyparcie - pisał Ari Shavit - miało fundamentalne znaczenie dla przetrwania Izraela. Bez niego nie dałoby się bowiem funkcjonować, budować, żyć. Uparte ignorowanie rzeczywistości było kluczem do sukcesu syjonizmu w pierwszych dziesięcioleciach XX wieku, tak jak nieświadomość przeszłości stała się kluczem do sukcesu Izraela w pierwszych dziesięcioleciach jego istnienia. Gdyby Izrael przyznał, że stało się to, co się stało, nie zdołałby przetrwać. Gdyby Izrael był łaskawy i współczujący, upadłby"168. Syjonistyczne narracje przez długi czas ignorowały niesprawiedliwości wobec ocalałych z Holokaustu.

Przełom nastąpił w trakcie procesu Eichmanna w 1960 roku, który dla Ben-Guriona miał być, jak to ujął Szimon Peres, „seminarium z historii Holokaustu dla całego narodu, a także dla świata"169. Dopiero wówczas zaczęto bez wstydu, z podniesioną głową mówić o mrocznych doświadczeniach z diaspory,

165 Tamże, s. 99.

166 T. SEgEv: Siódmy milion..., s. 151.

167 Tamże, s. 174. Por. także: J. Kaniuk: Adam, syn psa. Przeł. L. Kwiatkowski. „Literatura na Świecie" 2004, nr 11-12 (400-401), s. 287-311.

168 A. Shavit: Moja Ziemia Obiecana..., s. 188.

169 Ben Gurion..., s. 201. 
o bestialstwie nazistowskiego terroru, torturach i cenie ocalenia. I co ważniejsze - w końcu zaczęto słuchać. „W dawnej rywalizacji między »archeologiczną" tożsamością hebrajską a historyczną tożsamością żydowską, proces Eichmanna stał się punktem, w którym zmieniły się trajektorie i pierwsza - jak to określiła Anita Shapira - zaczęła opadać, a druga się wznosić. W kolejnych latach zmiana ta nabierała rozpędu"170. Szybko zrozumiano, że powszechnie znane kategorie bohaterstwa i odwagi nie przystają do czasu dymiących kominów krematoriów. Uświadomiono sobie wreszcie, że wówczas nie można było wybrać nawet sposobu umierania. „Proces Eichmanna znaczył początek - pisał Segev dramatycznej zmiany stosunku Izraelczyków do Zagłady. Przerażające historie, które wynurzyły się z głębi milczenia, zapoczątkowały proces utożsamiania się z cierpieniem ocalałych"171. Göran Rosenberg zwrócił uwagę, że w 1962 roku jedną piątą ludności żydowskiej stanowili ocalali z Zagłady. „Jerozolima pisał - sąsiadowała z Auschwitz"172. Otwarcie izraelskiego społeczeństwa na głos ocalałych prowadziło jednocześnie, niestety, do wykorzystania Zagłady w walce politycznej, w której stawką były doraźne - i nie zawsze szlachetne cele. „Od Aby Kownera po Menachema Begina, od Icchaka Sade po Ariela Szarona, od Ben-Guriona i Natana Altermana po Chaima Hefera i Beniamina Netanjahu, od prawicy po lewicę poprzez centrum i marginesy sceny politycznej, narracja o potędze izraelskiej postrzegana była nie tylko jako konieczność w kontekście konfliktu arabsko-izraelskiego, ale także jako rodzaj ekspiacji, która nadaje Zagładzie i historii sens a posteriori. Był to proces dialektyczny: pamięć o Zagładzie nadawała - pisała Idith Zertal - sens konfliktowi i zacierała jego wymiar polityczny i historyczny, podczas gdy opowieść o nim umacniała rolę Zagłady jako mitu założycielskiego izraelsko-syjonistycznej meta-narracji. W ten sposób Zagładę i bieżący konflikt wyrwano z kontekstu historycznego, pozbawiając je charakterystycznych dla wydarzenia historycznego złożoności i wewnętrznych sprzeczności. Granica, która je dzieliła, stawała się płynna i zarówno Zagłada, jak i konflikt były teraz odrębną, choć wewnętrznie powiązaną, mityczną całością, odporną na wszelką krytykę. Kontekst Zagłady i potęgi izraelskiej zaczynał odgrywać kluczową rolę w umacnianiu tożsamości narodowej, więzi społecznej i solidarności w nowym państwie"173. Instrumentalizacja Szoa służy stygmatyzacji moralnej przeciwników politycznych. „Retoryczne zaklęcia budzą dawną traumę tym razem w służbie oskarżycieli, którzy swoich wrogów porównują do nazistów, legitymizując $\mathrm{w}$ ten sposób - zwróciła uwagę Judith Butler - każdy akt przemocy przeciw owym wrogom"174. Butler przekonywała, że hasło „Holokaust” przywołuje się w Izraelu między innymi „w celu obu-

170 A. Shapira: Historia Izraela..., s. 314.

${ }_{171}$ T. Segev: Siódmy milion..., s. 337.

172 G. Rosenberg: Kraj utracony..., s. 266.

${ }^{173}$ I. Zertal: Naród i śmierć..., s. 285.

${ }^{174}$ J. ButLeR: Na rozdrożu..., s. 321. 
dzenia upiorów z przeszłości po to, by usprawiedliwiać nowe akty militarnej agresji”175.

Zagłada szybko stała się czymś na kształt świeckiej religii, spajającej wieloetniczne i wielokulturowe społeczeństwo izraelskie. „Izrael przejął - pisała Anita Shapira - społeczne upamiętnienie Żydów, którzy zginęli, jako rodzaj nieizraelskiej przeszłości, służący za wspólny fundament emocjonalny dla wszystkich Żydów świata"176. Odtąd Szoa była istotnym elementem tożsamości także dla imigrantów z krajów arabskich. „Liczba potomków tych, co przeżyli Zagładę, nieustannie rosła, przynajmniej od lat 70. XX wieku. Od tego momentu wszyscy chcieli należeć do ocalonych. Spora liczba Amerykanów pochodzenia żydowskiego, którzy nie przebywali w Europie podczas II wojny światowej, ani nie manifestowali jakiejś konkretnej solidarności z ofiarami w czasach Zagłady, oświadczali że są bezpośrednimi spadkobiercami ocalałych $\mathrm{z}$ machiny śmierci. Z kolei, z Iraku i Afryki Północnej przybyły dzieci tamtejszych Żydów, uznając siebie za nierozdzielną część powiększającej się liczby ofiar nazizmu. W Izraelu powstało nawet specjalne określenie »drugie pokolenie Shoah«, później i »trzecie pokolenie«. Tak więc symboliczny kapitał minionego cierpienia okazywał się pisał Sand - dziedziczny, jak każdy kapitał..."177. Zagłada wypełniła potrzebę odwoływania się do przeszłości, do wspólnego dziedzictwa oraz historii, której nowo utworzonemu państwu, tak zdecydowanie odrzucającemu kulturę diaspory, ewidentnie brakowało. „Izraelczycy są potomkami narodu, religii i kultury, które odsunęły na bok teraźniejszość, a przyszłość złożyły w rękach wiary i losu. Przeszłość zatem stała się dla nich przedmiotem kultu. Od początku lat osiemdziesiątych wyznają - pisał Tom Segev - moreszet ha-szoa - to dość dziwne wyrażenie oznacza "dziedzictwo Zagłady" "178. W latach 90. w Izraelu można było zaobserwować wzmożone zainteresowanie tematyką Holokaustu. Owa „gorliwość w powrocie do przeszłości - stwierdził Segev - jest często nie mniej problematyczna i pełna sprzeczności niż wcześniejsza tendencja, by jej zaprzeczac'"179. Zainteresowanie przeszłością $\mathrm{w}$ niewielkim tylko stopniu przełożyło się na stosunek wobec żyjących wówczas jeszcze ocalałych oraz poprawę ich losu (często żyli oni i umierali w zapomnieniu, w bardzo złych warunkach). Jak się łatwo domyślić, główną konsekwencją otwarcia się społeczeństwa na dyskusję o nieodległej historii była stała odtąd obecność Holokaustu w mediach. Zagłada stała się - co więcej - „głównym tematem literatury i poezji, teatru, kina i telewizji" ${ }^{180}$, jak również sztuk wizualnych. Odegrała istotną rolę w procesie tworzenia tożsamości Izraelczyków oraz polityce Państwa Izrael; znaczące jest

\footnotetext{
175 Tamże, s. 324.

176 A. Shapira: Historia Izraela..., s. 537.

177 Sh. SAnd: Dlaczego przestałem być Żydem..., s. 91-92.

178 T. Segev: Siódmy milion..., s. 477-478.

179 Tamże, s. 478.

180 Tamże, s. 481.
} 
zarówno jej przemilczenie w latach 50., wiążące się pośrednio z poczuciem winy jiszuwu ${ }^{181}$, który zdawał sobie sprawę, że nie zrobił wszystkiego, co było możliwe, by ratować europejskich Żydów ${ }^{182}$, jak i swoista eksplozja zainteresowania Zagładą po procesie Eichmanna, gdy zaczęto używać związanej z nią retoryki również w politycznych celach. „W dialektycznym procesie oswajania i wykluczania, pamiętania i zapominania, społeczeństwo izraelskie nieustająco definiowało samo siebie w relacji do Zagłady, uważając się za dziedzica, a zarazem za prokuratora ofiar, żałując za ich winy i jednocześnie - pisała Idith Zertal - dokonując odkupienia ich śmierci"183.

Amos $\mathrm{Oz}$ i Fania Oz-Salzberger zwrócili uwagę, że mówiący po hebrajsku dosłownie patrzą w przeszłość. „Przyjęliśmy - pisali - zachodnią ideę postępu. Ale nasz język po cichu posługuje się innym kompasem. Nadal patrzy wstecz, aż do Abrahama, który hen gdzieś prowadził swoje stada, zmierzając z Ur Kasdim do Ziemi Obiecanej”184. יזכור / Yizkor (czyt. yizkor, czyli „wspomnij”) to tytuł pracy fotograficznej Haima Maora z 2006 roku, a jednocześnie nazwa żałobnej modlitwy pamięci, Oby wspomniał [Pan dusze], odmawianej cztery razy w roku (Jom Kipur, Sukot, Pesach i Szawuot) przez każdego, kto stracił rodziców lub inną ukochaną osobę. יזכור ויכרוּ odmawia się także w Dzień Zagłady Jom ha-Szoa (יום הזיכרון לשואה ולגבורה), Dzień Pamięci - Jom ha-Zikaron oraz Dzień Niepodległości - Jom ha-Acma’ut (יום העצמאות), podczas religijnej ceremonii przy Murze Zachodnim oraz uroczystości na Wzgórzu Herzla, gdzie obowiązuje - zwróciła uwagę Anita Shapira - wersja Berla Katznelsona napisana dla uczczenia poległych w Tel Chaj, zaczynająca się słowami „Oby wspomniał lud Izraela” zamiast „Oby wspomniał [Pan]"185. Zmiany wprowadzone przez Katznelsona są, wbrew pozorom, znaczące. „Aby zjednoczyć naród, syjonizm wyeliminował - spostrzegł Yakov M. Rabkin - metafizyczny aspekt religii, pozostawiając jej społeczne funkcje"186. Katznelson, postępując w myśl tej właśnie zasady, zmienił tekst modlitwy jizkor („będzie pamiętał”), upamiętniającej zmarłych. „Oryginalna modlitwa jest błaganiem Boga o zachowanie pamięci o zmarłych bez wymawiania przyczyny ich śmierci; wersja syjonistyczna nawołuje naród żydowski do pamięci o swoich bohaterach, »którzy oddali swoje życie za honor Izraela i honor Ziemi Izraela«. Tak jak w przypadku innych nacjonalizmów europejskich, pamięć o poległych bohaterach stała się - stwierdził Rabkin - orężem w walce o polityczną niepodległość, stąd przeniesienie judaistycznych symboli religijnych do sfery

\footnotetext{
181 Por. A. Shapira: Historia Izraela..., s. 264.

182 Por. Ben Gurion..., s. 92-100.

183 I. Zertal: Naród i śmierć..., s. 15.

184 A. Oz, F. Oz-SAlzberger: Żydzi i słowa..., s. 148.

185 Por. A. Shapira: Historia Izraela..., s. 295-296.

186 Y.M. RABKIN: $W$ imię Tory..., s. 45.
} 
politycznej"187. Trzeba zwrócić uwagę również na wymowę swoistej dramaturgii, jaką tworzą następujące po sobie święta. „Sekwencja świąt, obchodzonych w ciągu kilku kolejnych dni, wiedzie - spostrzegł Artur Jasiński - od pustki i pamięci (Holocaust), poprzez zadumę nad ofiarą życia poległych żołnierzy (Zwycięstwo), po triumfalną radość (Niepodległość)"188. Jak do tego doszło? „Kiedy w końcu roku 1951 ustalono datę dnia pamięci Zagłady, Jom ha-Szoa, w żydowskim kalendarzu (dwudziestego siódmego dnia miesiąca nisan), okazało się, że następnego dnia obchodzony jest dzień poległych żołnierzy Izraela, Jom ha-zikaron, który poprzedza dzień izraelskiej niepodległości, Jom ha-Acmaut. Trzy ogniwa mistycznego łańcucha: katastrofa - bohaterskie ofiary - zbawienie. Lepszej konstrukcji - podsumował Göran Rosenberg - nikt by nie wymyślił”189. יזכור to zdjęcie wykonane w kibucu Tel Katzir (תל קציר), znajdującym się w Dolnej Galilei, na południowy wschód od Jeziora Tyberiadzkiego. Na metalowej konstrukcji (przypominającej kartkę z zeszytu w kratkę) znajdują się resztki wypalonego materiału będącego pozostałością napisu z ognia, czyli tzw. כתובת אש (czyt. ktowet esz), towarzyszącego wieczornej ceremonii Dnia Pamięci. Fotografia została wykonana dzień po ceremonii. Litera „waw” () zniknęła, została bowiem całkowicie wypalona. $\mathrm{W}$ tle widać góry oraz miasto Tyberiada, które było pierwszym mieszanym, żydowsko-arabskim miastem, zdobytym przez Haganę podczas wojny o niepodległość, skąd Palestyńczycy zostali „ewakuowani” i gdzie wyburzono część starej arabskiej zabudowy. „Zaborcza polityka prowadzona przez państwo izraelskie - pisał Jasiński - wywołuje ciągłe konflikty narodowych pamięci. Pamięć arabskich ofiar jest odmienna od pamięci zwycięzców. Przeszłość ciągle tu powraca jako źródło współczesnych konfliktów”'190. Konfliktów, jak przyjęło się sądzić, niemożliwych do rozwiązania. „»Cudowne« zdobycie »świętej« ziemi nadało moc mesjanistycznemu uzasadnieniu narodzin Izraela, a zatem i mesjanistycznej interpretacji Zagłady, Auschwitz jeszcze wyraźniej stał się przedsionkiem Jerozolimy. Izrael jeszcze mocniej objawił się jako naród z misją do spełnienia. Oddanie całego kraju Izraela Erec Israel ha-szlema pod panowanie żydowskie było - jak to sarkastycznie określił Göran Rosenberg - boską odpowiedzią na Zagładę"191. Edgar Morin zwrócił uwagę na niepewność Izraela co do jego przyszłych losów pomimo i z powodu jego militarnej supremacji: „»Izrael-rozwiązanie« zamienił się w »Izrael-problem«, noszący w sobie zalążki własnej tragedii. Pragnienie Żydów, aby już nigdy nie przyszło im zmierzyć się z katastrofą Auschwitz, która dotknęła Żydów pozbawionych narodu, prowadzi ich, nieświadomych, do katastrofy narodu żydow-

\footnotetext{
187 Tamże.

188 A. Jasiński: Architektura i urbanistyka Izraela..., s. 211.

189 G. Rosenberg: Kraj utracony..., s. 276.

190 A. JAsıński: Architektura i urbanistyka Izraela..., s. 100.

191 G. Rosenberg: Kraj utracony..., s. 286.
} 
skiego"192. Pamiętanie, zdaje się mówić Haim Maor, to żydowski obowiązek. Jednak napis jest wypalony i niekompletny. „Chociaż traumy nie sposób przezwyciężyć za pomocą woli, da się ją przepracować w stopniu, w jakim będziemy pamiętać o tym, że stwarza ona - pisała Judith Butler - zagrożenie wchłonięcia teraźniejszości przez przeszłość czy ewokowania przeszłości jako teraźniejszości, tym samym przekreślając doświadczenie historycznego dystansu, owego interwału niezbędnego do podjęcia namysłu nad tym, jak należałoby stwarzać dalszy ciąg historii w świetle takiej a takiej przeszłości” ${ }^{193}$. Przepracowywanie traumy zdaje się - w postawie artystycznej Haima Maora - przywracaniem wypalonej pamięci. Powracając do koszmarów przeszłości, artysta demaskuje podstawy wielu politycznych, społecznych i etycznych dysfunkcji życia we współczesnym Izraelu.

\section{Bibliografia}

Artykuły o sztuce Haima Maora w języku polskim

Bar-On D., Maor H.: Od partykularyzmu do uniwersalizmu. Przeł. B. Juszczyk. „Pro Memoria" 2009, nr 2 (29), s. 145-147.

Barutin B.: Haim Maor - znicz pamięci. Artysta drugiego pokolenia po Holocauście. Przeł. B. Juszczy K. „Pro Memoria” 2009, nr 2 (29), s. 132-143.

JAкuвоwiCz R.: Midrasz wizualny albo trzecie znaczenie. Z Haimem Maorem rozmawia Rafał Jakubowicz. Przeł. R. Jakubowicz. „Midrasz. Pismo Żydowskie” 2014, nr 6 (182), listopad/grudzień, s. 5-11.

Jaкubowicz R.: Siedem, osiem, cztery, cztery, sześć. O sztuce Haima Maora. „Midrasz. Pismo Żydowskie” 2011, nr 4 (162), lipiec/sierpień, s. 54-59.

Maor H.: Zapomniane historie. Przeł. B. Juszczyк. „Pro Memoria” 2009, nr 2 (29), s. $125-127$.

Maor (Moshkovitz) H.: Sztuka i życie. Przeł. B. Juszczyк. „Pro Memoria” 2009, nr 2 (29), s. 128-131.

Katalogi wystaw indywidualnych Haima Maora (według daty publikacji)

Haim Maor: The Forbidden Library. Avraham Baron Art Gallery, Ben-Gurion University of the Negev, Beer-Sheva 1994.

${ }^{192}$ E. Morin: Świat nowoczesny a kwestia żydowska. Przeł. W. Prażuch. Warszawa 2010, s. 146.

${ }^{193}$ J. BUtler: Na rozdrożu..., s. 334-335. 
מאור : הספריה האסורה, הגלריה לאמנות ע"ש אברהם ברון, וניברסיטתא בן-גוריון בנגב, באר-שבע 1994 חיים מאור :

Haim Maor. The Faces of Race and Memory: Forbidden Library. Massuah - The Institute for the Study of the Holocaust, Kibbutz Tel Itzhak 2005

חיים מאור. פני הגזע ופני הזיכרון: הספרייה האסרה, משואה, המכון ללימודיו השואה, קיבוץ תל-יצחק, 2005 Haim Maor. They are Me. The Open Museum, Tefen and Omer Industrial Parks, 2011.

חיים מאור. הם אני, המויאון הפתוח, גני התעטייה תפן ועומר 2011

Katalogi wystaw zbiorowych, w których uczestniczył Haim Maor (według daty publikacji)

Bare Life. On the Seam / Socio-Political Contemporary Art Museum, Jerusalem 2007.

חיים חשופים, על התפר מוזיון חברתי לאומנות עכשווית, ירושלים 2007 תימים

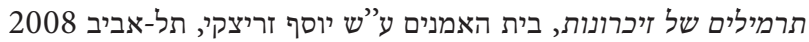
חיים מאור וחאדר ושאה בדיאלוג בין תרבויות, האוניברסיטה הפתוחים עיבה, גלריה עירונית, כפר סבא 2009

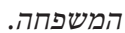

Portraits of Cain. Ben-Gurion University of the Negev, Department of the Arts, Beer Sheva 2012.

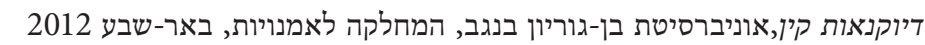

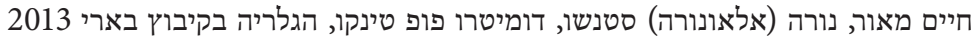

Wybrana literatura w języku polskim

Agamben G.: Co zostaje z Auschwitz. Archiwum i świadek. Przeł. S. Królak. Warszawa 2008.

Améry J.: Poza wina i karą. Przeł. R. Turczyn. Kraków 2007.

Arendt H.: Eichmann w Jerozolimie. Rzecz o banalności zła. Przeł. A. Szostriewicz. Kraków 1998.

Bauman Z.: Nowoczesność i Zagłada. Przeł. T. Kunz. Kraków 2009.

Ben Gurion. Żywot polityczny. Z Szimonem Peresem rozmawia David Landau. Przeł. H. JANKowska. Warszawa 2013.

Bronowski J.: Jakie sq widoki Biblii. Przeł. L. Kwiatkowski. „Literatura na Świecie” 2004, nr 11-12 (400-401), s. 417-422.

Buber M.: Obrazy dobra i zła. Przeł. M. Masny. Gliwice 2017.

Butler J.: Na rozdrożu. Żydowskość i krytyka syjonizmu. Przeł. M. Filipczuk. Warszawa 2014.

Engelking B.: „Czas przestał dla mnie istnieć”. Analiza doświadczenia czasu w sytuacji ostatecznej. Warszawa 1996.

Finkielkraut A.: Niewdzięczność. Rozmowa o naszych czasach (rozmawiał Antoine Robitaille). Przeł. S. KRólAK. Warszawa 2005.

Finkielkraut A.: W imię innego. Antysemicka twarz lewicy. Przeł. R. Lis. Warszawa 2005.

Forecki P.: Po Jedwabnem. Anatomia pamięci funkcjonalnej. Warszawa 2018. 
Gebert K.: Miejsce pod słońcem. Wojny Izraela. Warszawa 2008.

Glucksmann A.: Rozprawa o nienawiści. Przeł. W. Prażuch. Warszawa 2008.

GRABSKI A.: Lewica przeciwko Izraelowi. Studia o żydowskim lewicowym antysyjonizmie. Warszawa 2008.

Grossman D.: Patrz pod: Miłość. Przeł. M. Sommer. Warszawa 2008.

Gruber R.E.: Odrodzenie kultury żydowskiej w Europie. Przeł. A. Nowakowska. Sejny 2004.

Hartmann G.: Bitburg. Przeł. T. Łysak. „Literatura na Świecie” 2004, nr 1-2 (390-391), s. $329-341$.

Herzl T.: Państwo Żydowskie. Próba nowoczesnego rozwiązania kwestii żydowskiej. Przeł. J. Surzyn. Kraków 2006.

Hirsch M.: Pokolenie postpamięci. Przeł. M. Borowski, M. Sugiera. „Didaskalia. Gazeta Teatralna" 2011, nr 105, s. 28-36.

Hussakowska M.: Minimalizm. Kraków 2003.

Janicka E., Żukowski T.: Przemoc filosemicka? Nowe polskie narracje o Żydach po roku 2000. Warszawa 2016.

JasıńsKi A.: Architektura i urbanistyka Izraela. Kraków 2016.

JedlińsKa E.: Sztuka po Holocauście. Łódź 2001.

Kaniuk J.: Adam, syn psa. Przeł. L. Kwiatkowski. „Literatura na Świecie” 2004, nr 11-12 (400-401), s. 287-311.

KLemperer V.: LTI. Notatnik filologa. Przeł. J. Zychowicz. Kraków 1983.

Kowalczyk I.: Podróż do przeszłości. Interpretacje najnowszej historii w polskiej sztuce krytycznej. Warszawa 2010.

Levi P.: Czy to jest człowiek. Przeł. H. Wiśniowska. Oświęcim-Warszawa 1996.

Levi P.: Pograżeni i ocaleni. Przeł. S. Kasprzysiak. Kraków 2007.

Lorenc M.: Trzęsienie Ziemi Świętej. Konflikt bliskowschodni i próby jego rozwiązania. Poznań 2007.

Mopsiк Ch.: Kabała. Przeł. A. Szymanowski. Warszawa 2001.

Morin E.: Świat nowoczesny a kwestia żydowska. Przeł. W. Prażuch. Warszawa 2010.

NizioŁek G.: Polski teatr Zagłady. Warszawa 2013.

Oz A.: Do fanatyków. Trzy refleksje. Przeł. L. Kwiatkowski. Poznań 2018.

Oz A.: Opowieść o miłości i mroku. Przeł. L. Kwiatkowski. Warszawa 2005.

Oz A., Oz-Salzberger F.: Żydzi i słowa. Przeł. P. Paziński. Warszawa 2014.

PAppé I.: Czystki etniczne w Palestynie. Przeł. A. SAK. Warszawa 2017.

Pluszka A.: Trzy klocki w puzzlach. Rozmowa z Piotrem Pazińskim. Dostępne w Internecie: http://www.dwutygodnik.com/artykul/6855-trzy-klocki-w-puzzlach.html [data dostępu: 14.08.2018].

Rabkin Y.M.: W imię Tory. Żydzi przeciwko syjonizmowi. Przeł. Ł. BrzezińsKi. Warszawa 2007.

Rosenberg G.: Kraj utracony. Moja historia Izraela. Przeł. M. Haykowska. Wołowiec 2011.

Rosenfeld A.H.: Podwójna śmierć. Rozważania o literaturze Holocaustu. Przeł. B. KRAwCOWICZ. Warszawa 2003.

Saltzman L.: Awangarda i kicz raz jeszcze. O estetyce reprezentacji. Przeł. K. Bojarska. „Literatura na Świecie” 2004, nr 1-2 (390-391), s. 201-215. 
SAnd Sh.: Dlaczego przestałem być Żydem. Spojrzenie Izraelczyka. Przeł. I. BAdowska. Warszawa 2014.

SAnd Sh.: Kiedy i jak wynaleziono naród żydowski. Przeł. Н. Zвоnikowska-BERnATOWICZ. Warszawa 2014.

SAnd Sh.: Kiedy i jak wynaleziono Ziemię Izraela. Od Ziemi Świętej do ojczyzny. Przeł. M. KozŁowski. Warszawa 2015.

SARtre J.-P.: Rozważania o kwestii żydowskiej. Przeł. J. Lisowski. Łódź 1992.

Scholem G.: Kabała i jej symbolika. Przeł. R. Wojnakowski. Warszawa 2014.

Scholem G.: Mistycyzm żydowski i jego główne kierunki. Przeł. I. Kania. Warszawa 2007.

Scholem G.: O mistycznej postaci bóstwa. Przeł. A.K. HaAs. Warszawa 2010.

Scholem G.: O podstawowych pojęciach judaizmu. Przeł. J. Zychowicz. Warszawa 2015.

Schwan G.: Polityczny sens przemilczanej winy. „Gazeta Wyborcza” z 31 sierpnia-1 września 2002 r. [dodatek: „Gazeta Świąteczna”], s. 18-20.

Segev T.: Izrael po procesie Eichmanna. Przeł. A. CzarnackA. „Le Monde Diplomatique" 2008, nr 5 (27), maj (edycja polska), s. 7.

Segev T.: Siódmy milion. Izrael - piętno Zagłady. Przeł. B. Gadomska. Warszawa 2012. Shallcross B.: Rzeczy i Zagłada. Kraków 2012.

Shapira A.: Ben Gurion. Twórca współczesnego Izraela. Przeł. H. Jankowska. Warszawa 2018.

Shapira A.: Historia Izraela. Przeł. A.D. KamińsKa. Warszawa 2018.

Shavit A.: Moja Ziemia Obiecana. Triumf i tragedia Izraela. Przeł. B. Gutowska-NowAK. Kraków 2014.

Struk J.: Holokaust w fotografiach. Interpretacje dowodów. Przeł. A. Antosiewicz. Warszawa 2007.

Ślady Holokaustu w imaginarium kultury polskiej. Red. J. Kowalska-Leder, P. DobroSIELSKI, I. KurZ, M. SzPAKOWSKa. Warszawa 2017.

Traverso E.: Europejskie korzenie przemocy nazistowskiej. Przeł. A. Czarnacka. Warszawa 2011.

Traverso E.: Historia jako pole bitwy. Przeł. F. Nowicki. Warszawa 2014.

Trepp L.: Żydzi. Naród, historia, religia. Przeł. S. Lisiecka. Warszawa 2009.

Tyler P.: Twierdza Izrael. Zakulisowa historia elit wojskowych, które uparcie bronia się przed pokojem. Przeł. N. Radomski. Poznań 2018.

WesoŁowska D.: Słowa z piekieł rodem. Lagerszpracha. Kraków 1996.

Zertal I.: Naród i śmierć. Zagłada w dyskursie i polityce Izraela. Przeł. J.M. KŁoczowSKI. Kraków 2010.

Ziegler J.: Szwajcaria, złoto i ofiary. Przeł. E. Cylwik. Warszawa 2016. 


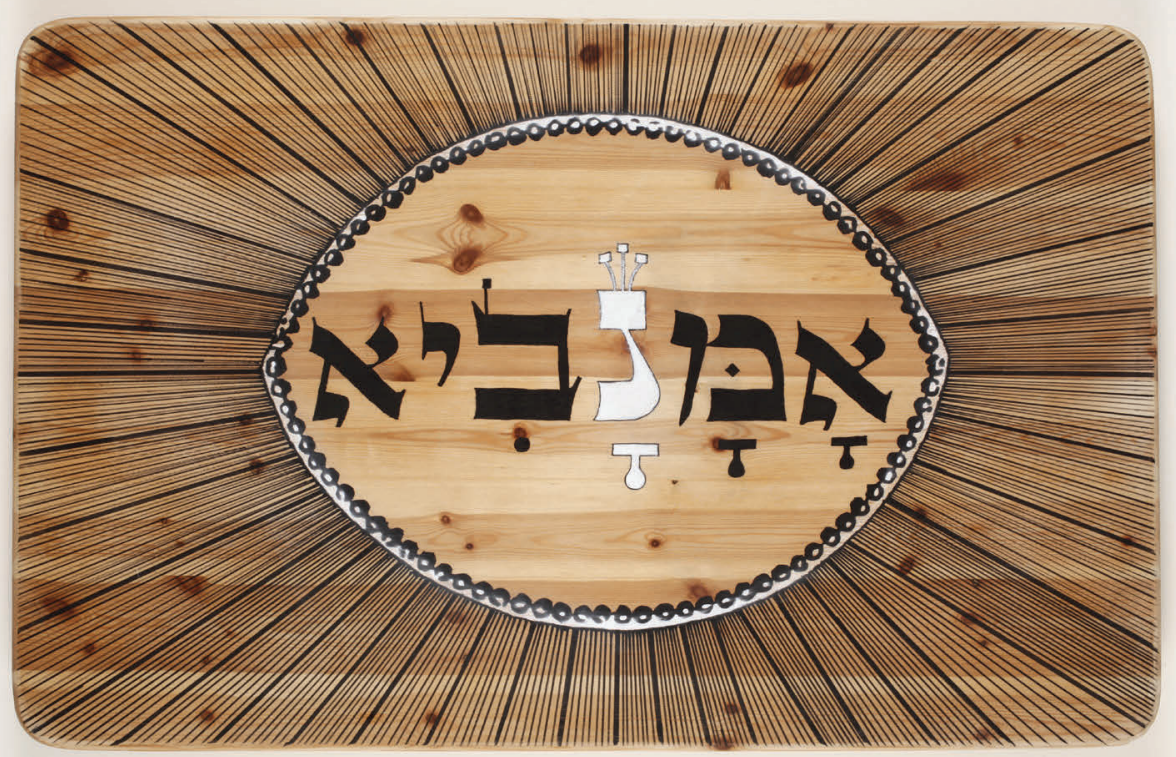

1. Haim Maor, אמנביא / ArtistProphet, 2011

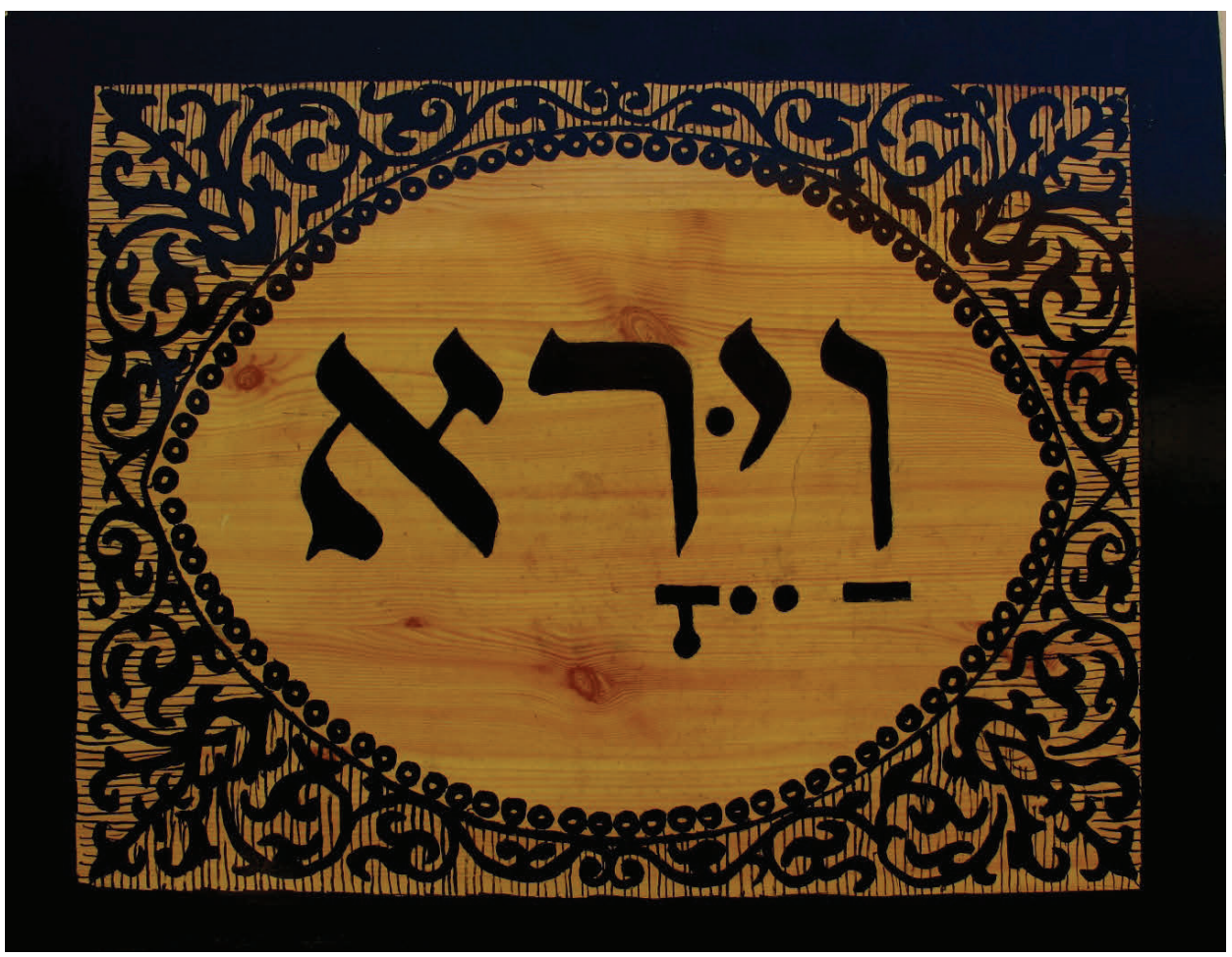

2. Haim Maor, (וירא) / Reiya/Yira'a (Vayare/Vayera), 1991/2007 

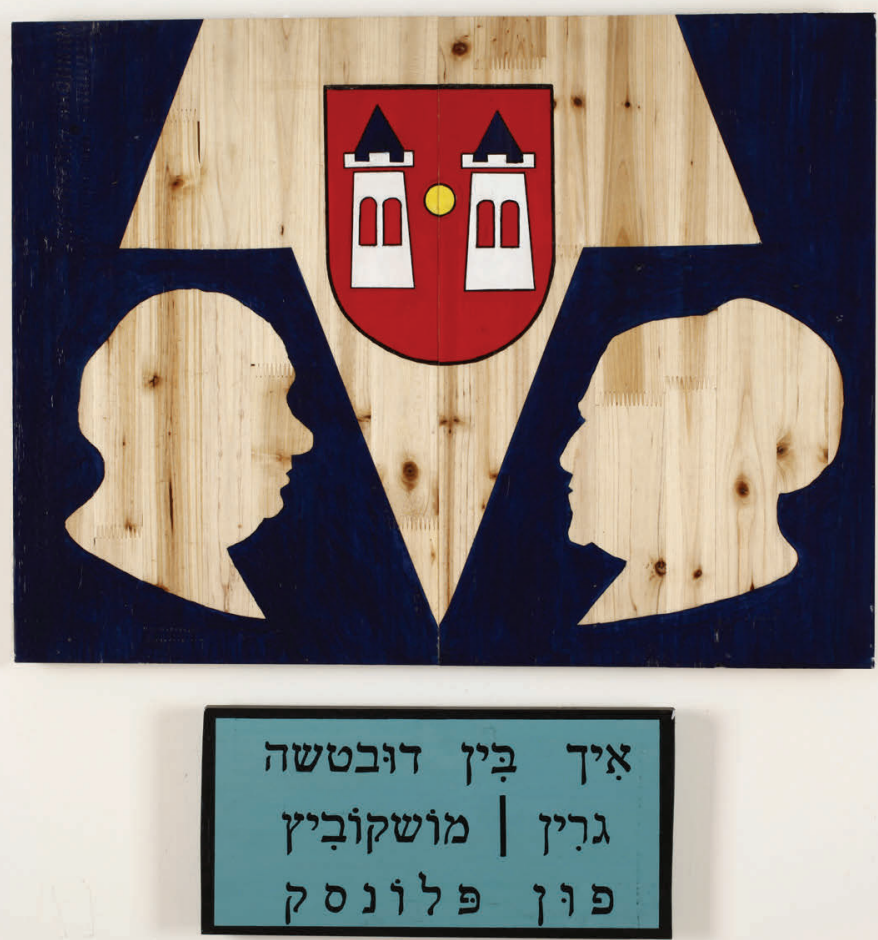

3. Haim Maor, דו / du David, 2010

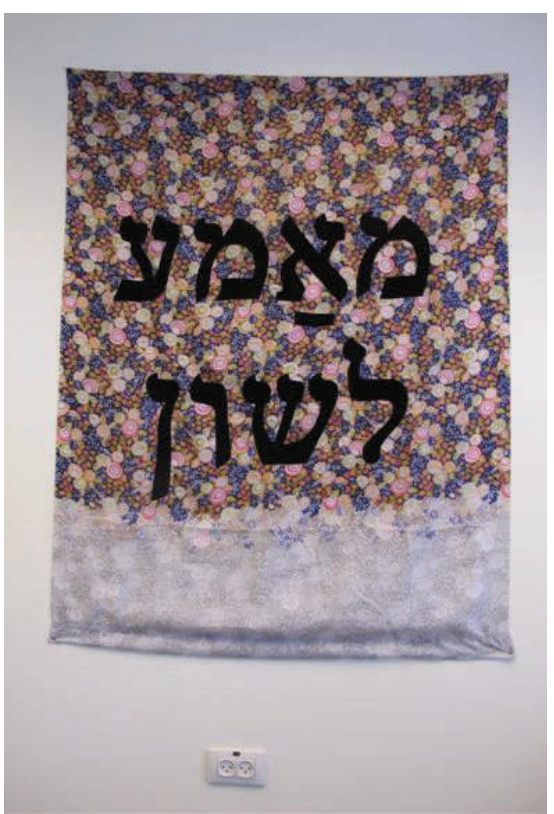

4. Haim Maor, מאמע-לשון / Mother Tongue, 20062007 

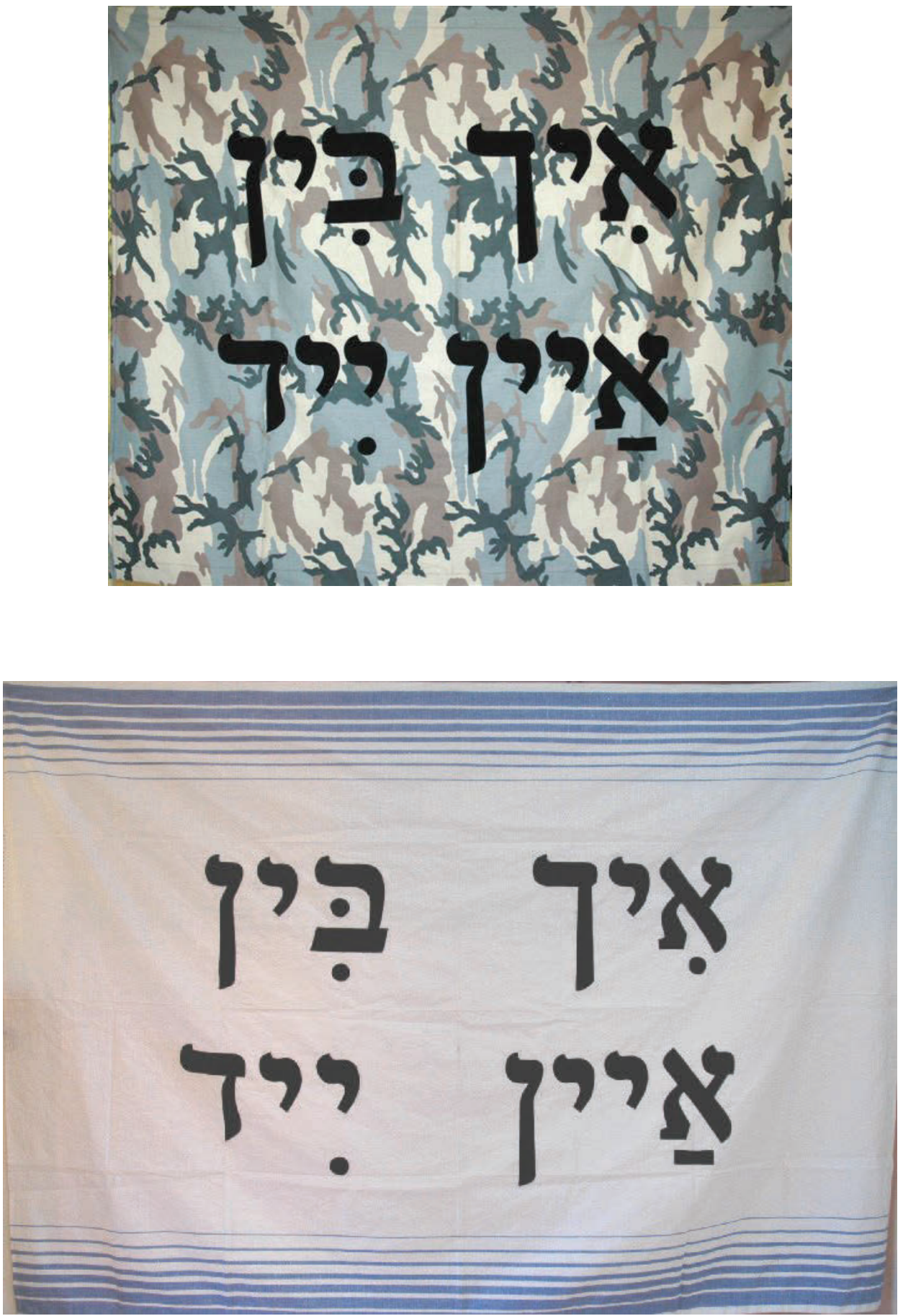

5. Haim Maor, cykl prac איך בין איין איד I am a Jew, 2006-2008 

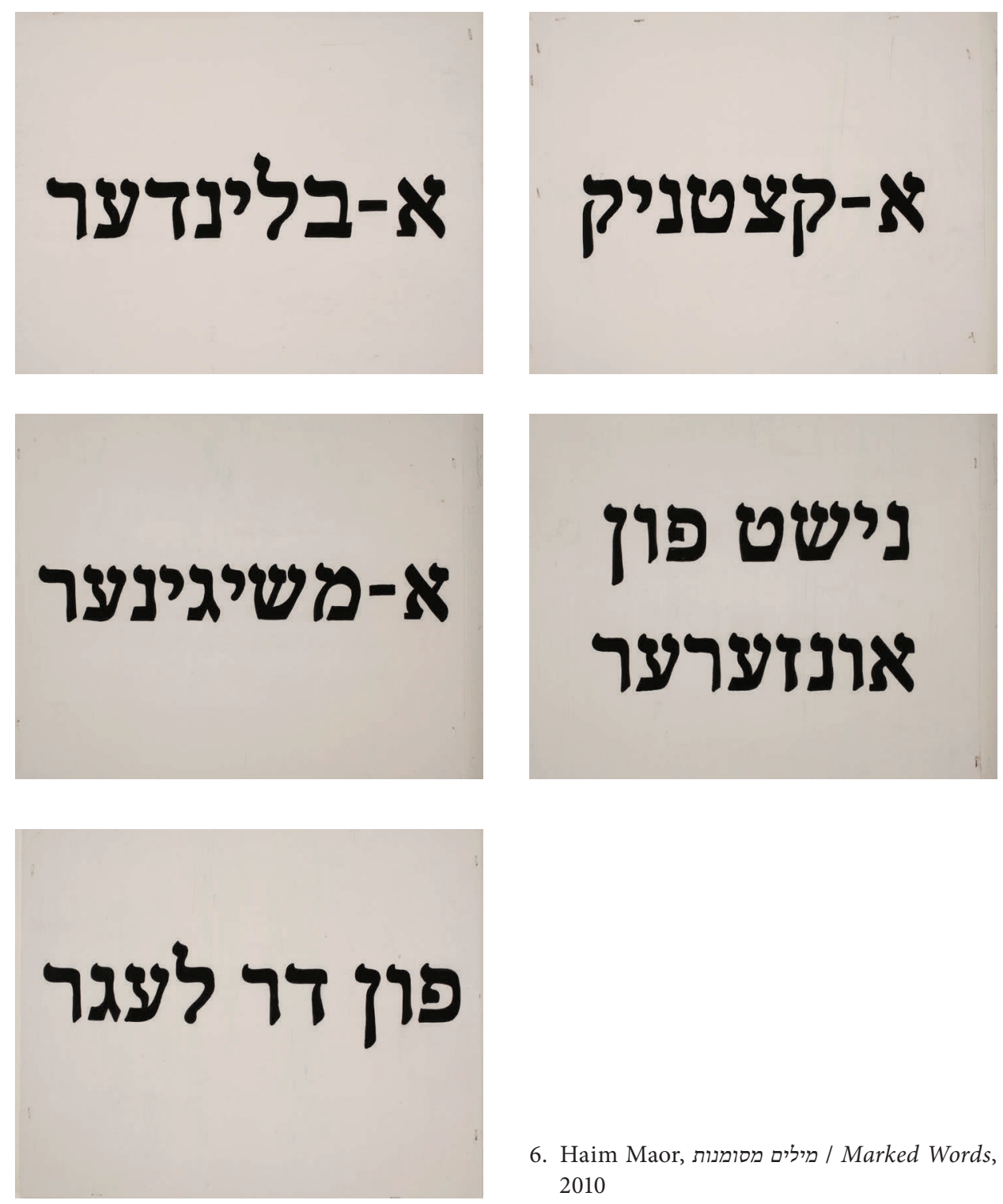

6. Haim Maor, מילים מסומנות / Marked Words, 2010 


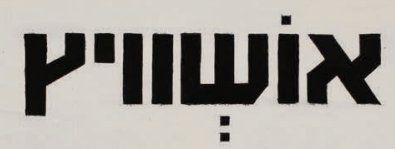 P"X}

\section{Austhwitz}

Bder

\section{䖡 Seblowiz}

\section{Ausch -- witz Moschkowitz}

7. Haim Maor, מחקר אטימולוגי / Etymological Study, 2011 


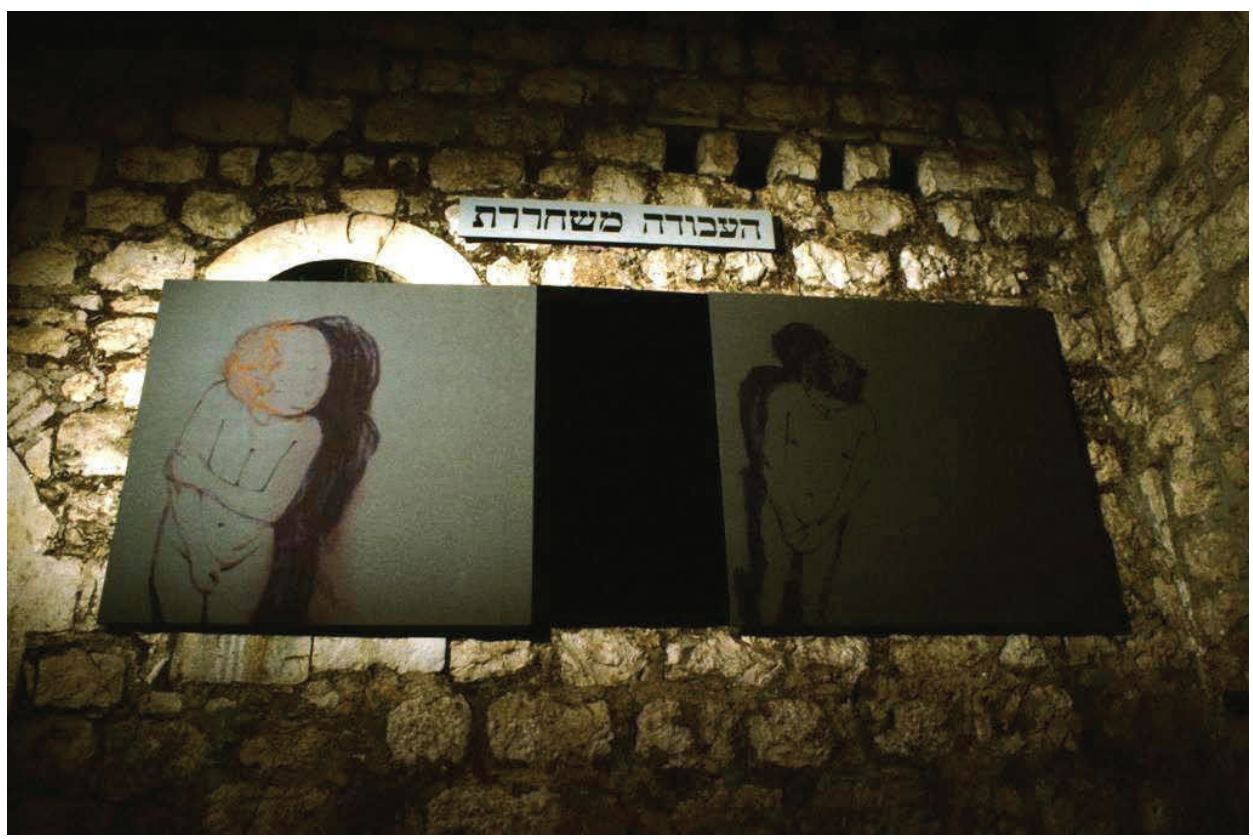

8. Haim Maor, העבודה משחררת / Arbeit Macht Frei, 1986

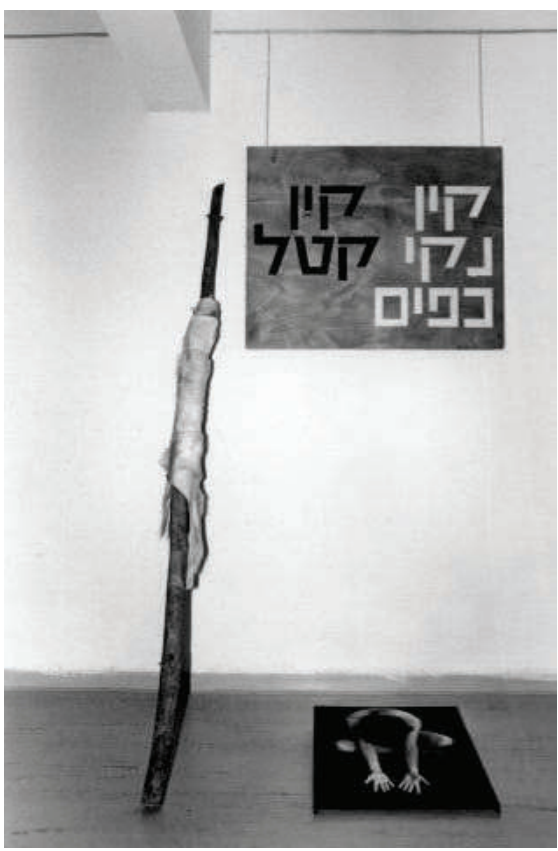

9. Haim Maor, קין נקי כפיים / Innocent Cain, 1978

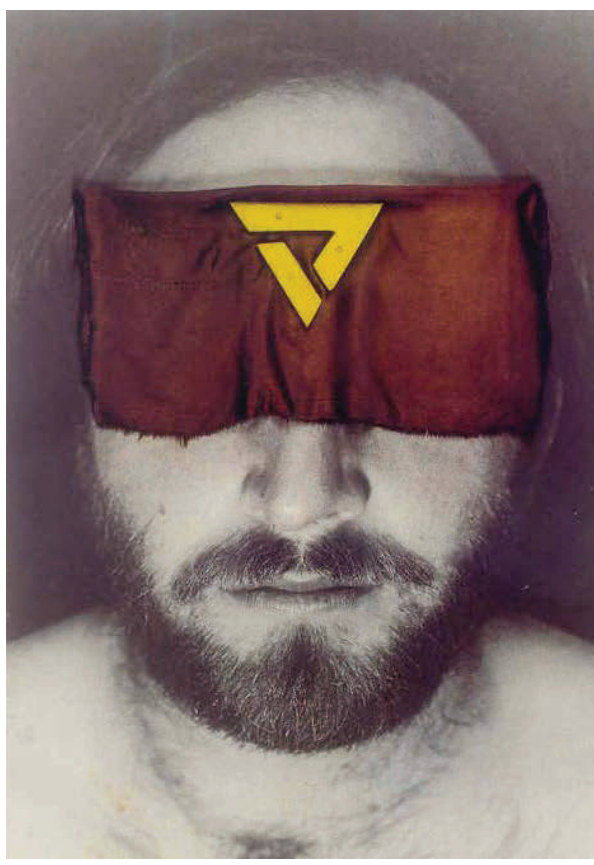

10. Haim Maor, אות קין / The Mark of Cain, 1978 


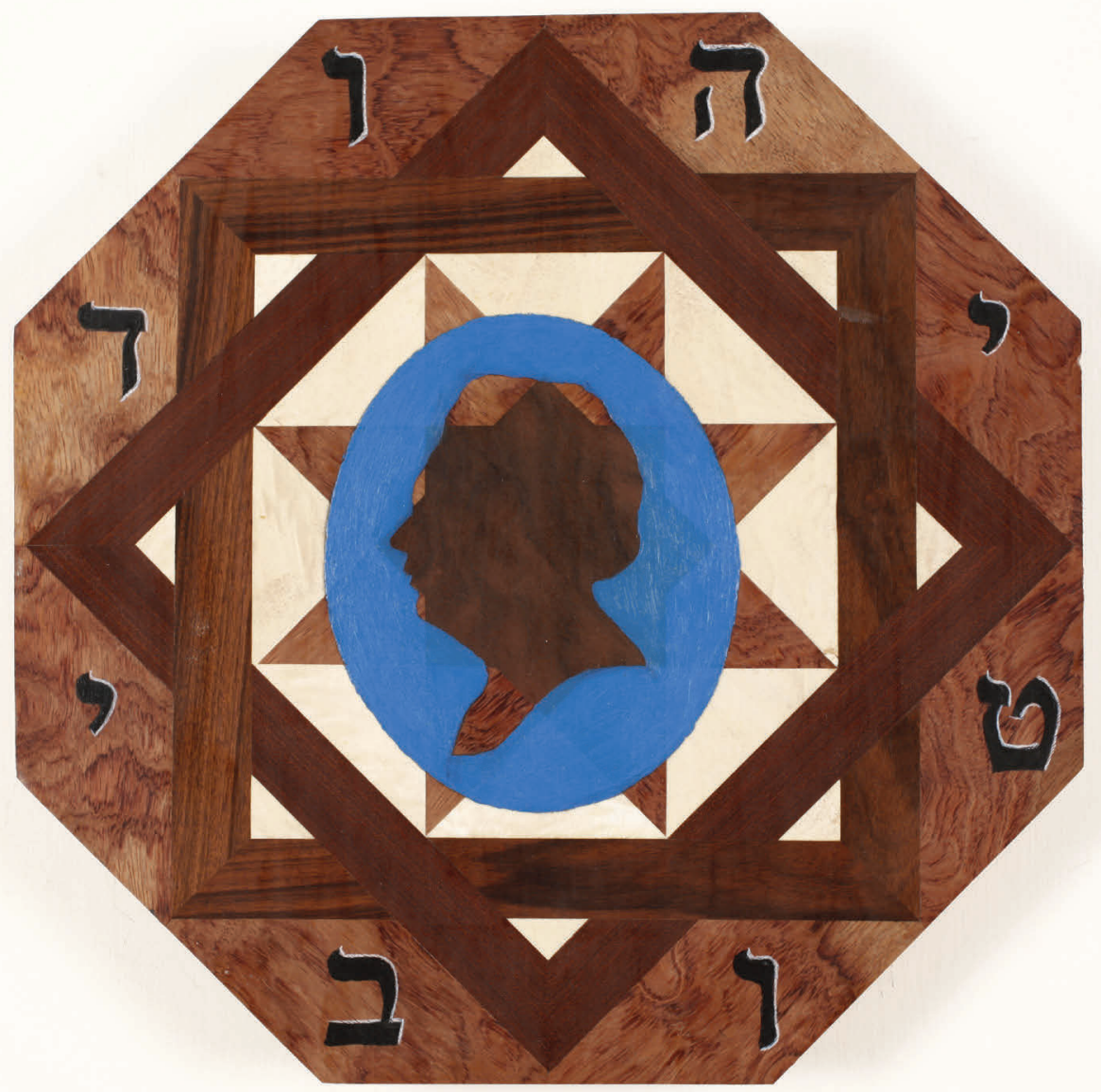

11. Haim Maor \& Mohammad Said Kalash, יהודי טוב / Good Jew, 2010 


\begin{tabular}{|c|c|c|c|c|c|}
\hline FOOD & LUGGAGE & WORK & עבודה & מזוודה & אוכל \\
\hline LOVE & TRAIN & HUNGER & רעב & רכבת & אהבה \\
\hline MOTHER & CONTROL & VICTIM & קורבן & פיקוח & אמיא \\
\hline FATHER & DANGER & SURVIVE & הישרדות & סכנה & אבא \\
\hline DRESS & DOG & TERMINATION & השמדה & כלבים & בגד \\
\hline HOME & CAMP & GAS & $\mathbf{T}$ & מחנה & בית \\
\hline FENCE & SELECTION & DEATH & תוIn & סלקציה & גדר \\
\hline LIFE & NAKED & SILENCE & שתיקה & ע'רום & חיים \\
\hline MEMORIES & HAIR & SMOKE & עשן & שיער & זיכרונות \\
\hline CHILDREN & TEETH & PRAYER & תבילה & שיניים & ילדים \\
\hline FATE & SKIN & SOUL & נשמה & עור & גורל \\
\hline TRANSPORT & SHOWER & WITNESS & עד & מקלחת & הובלה \\
\hline PAIN & BOOTS & FORGET & שכחה & מגכיים & כאב \\
\hline FEAR & NUMBER & END & סוך & מספר & פחד \\
\hline
\end{tabular}

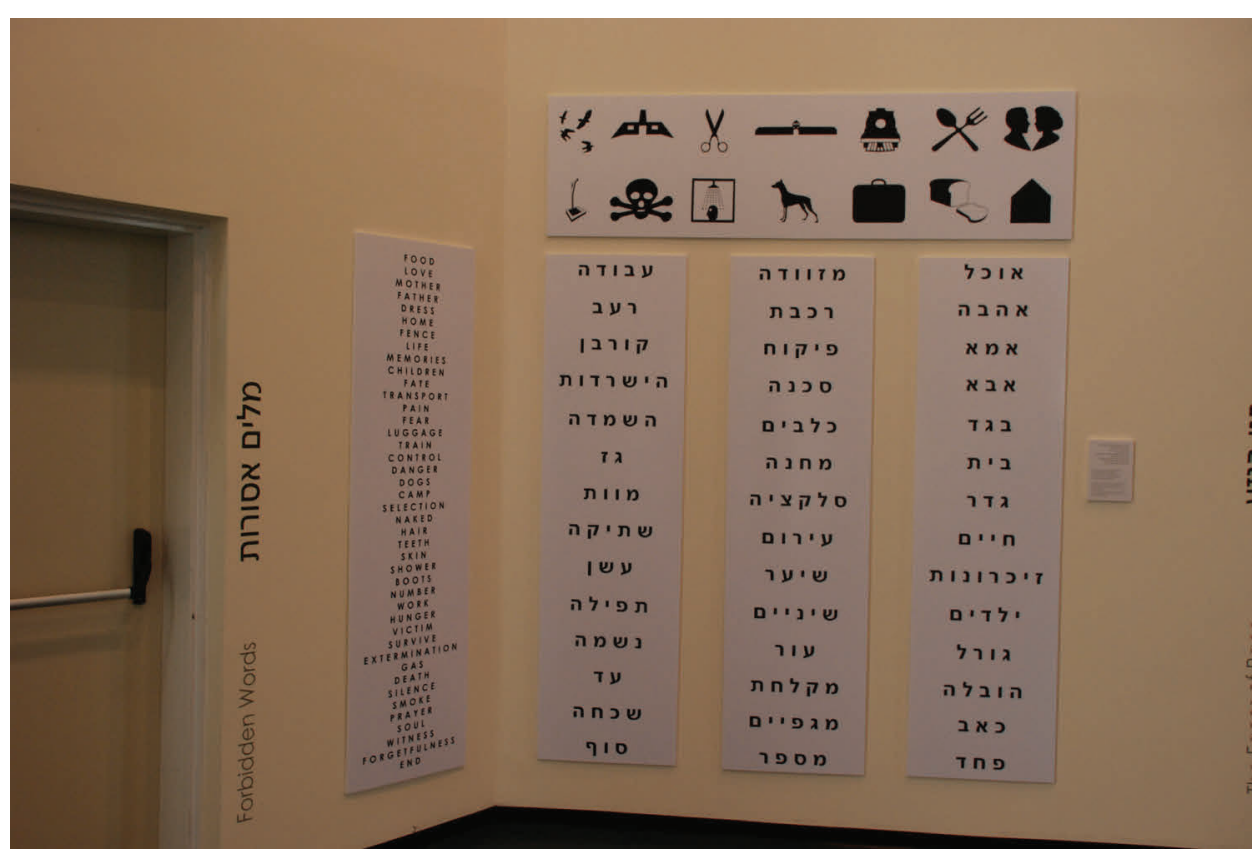

12. Haim Maor, מילים אסורות/Forbidden Words, 1988 


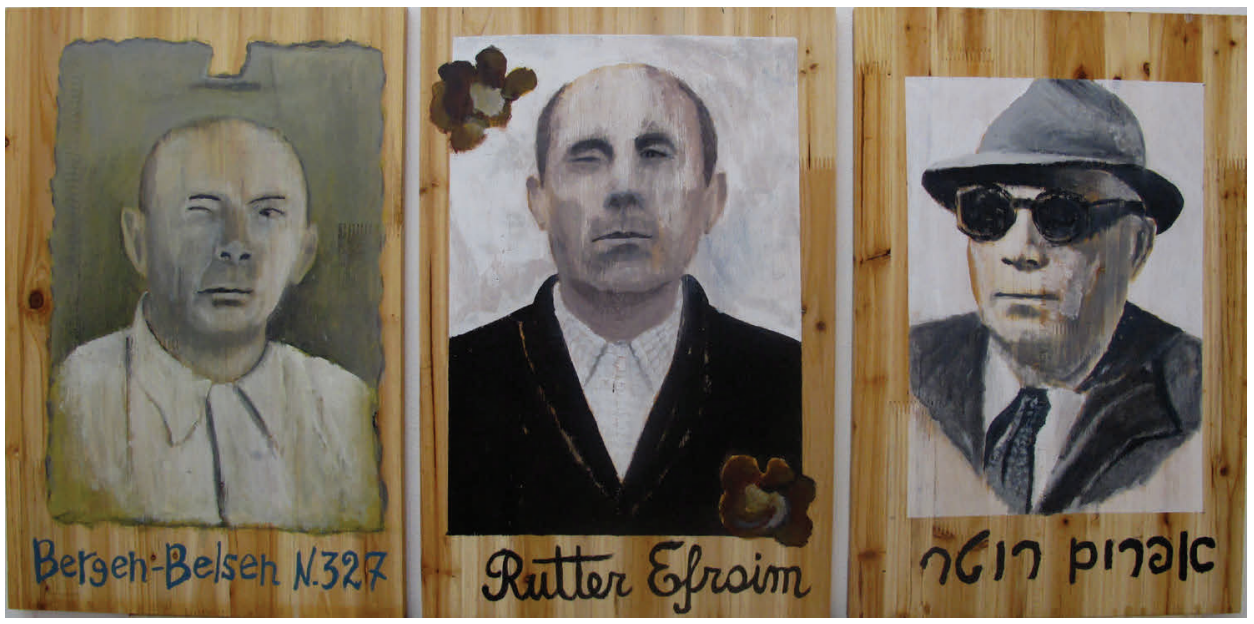

13. Haim Maor, שלושה מצבי עיוורון. סבה Three Stages of Blindness (My Grandfather), 2010 

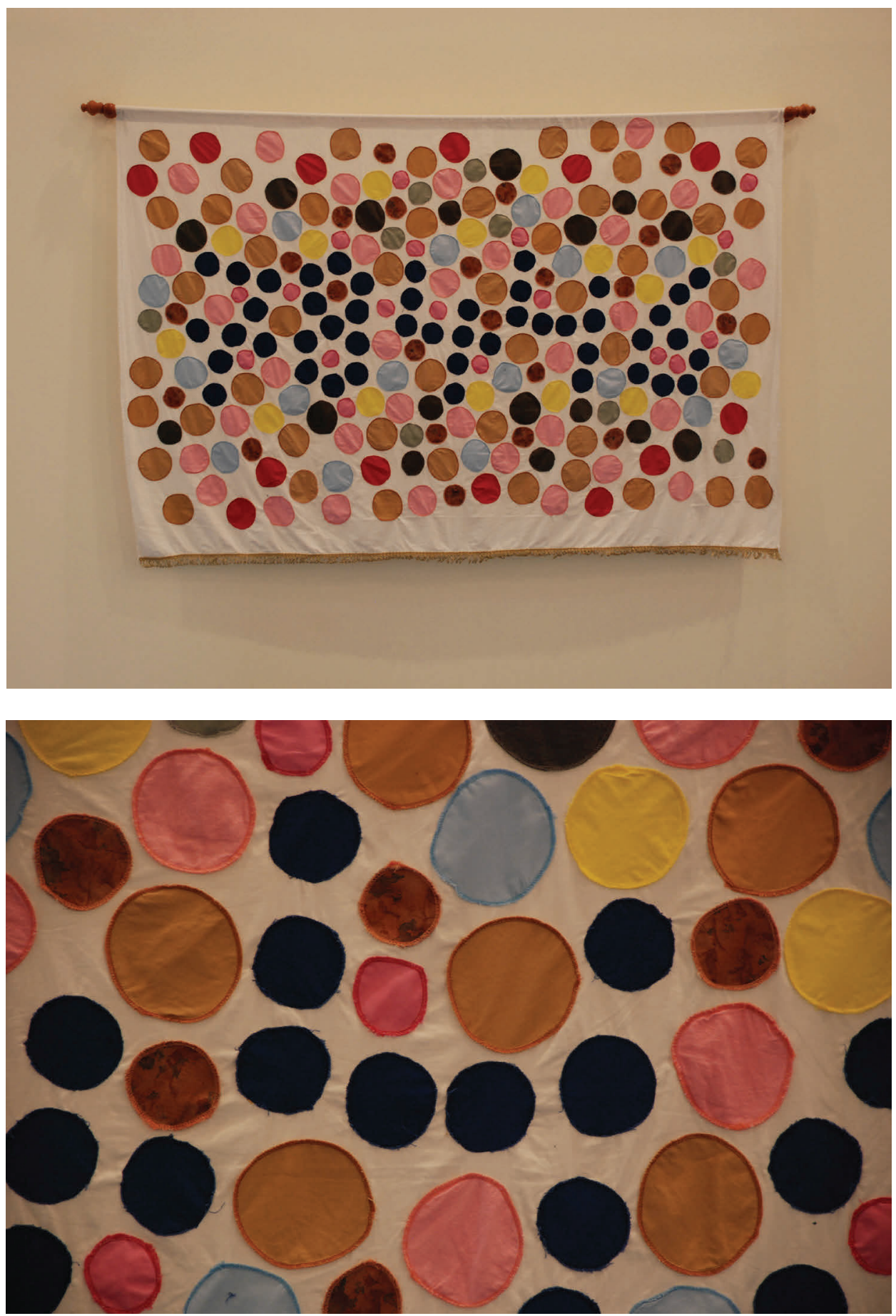

14. Haim Maor, 78446 (Color Blindness Test), 1993 


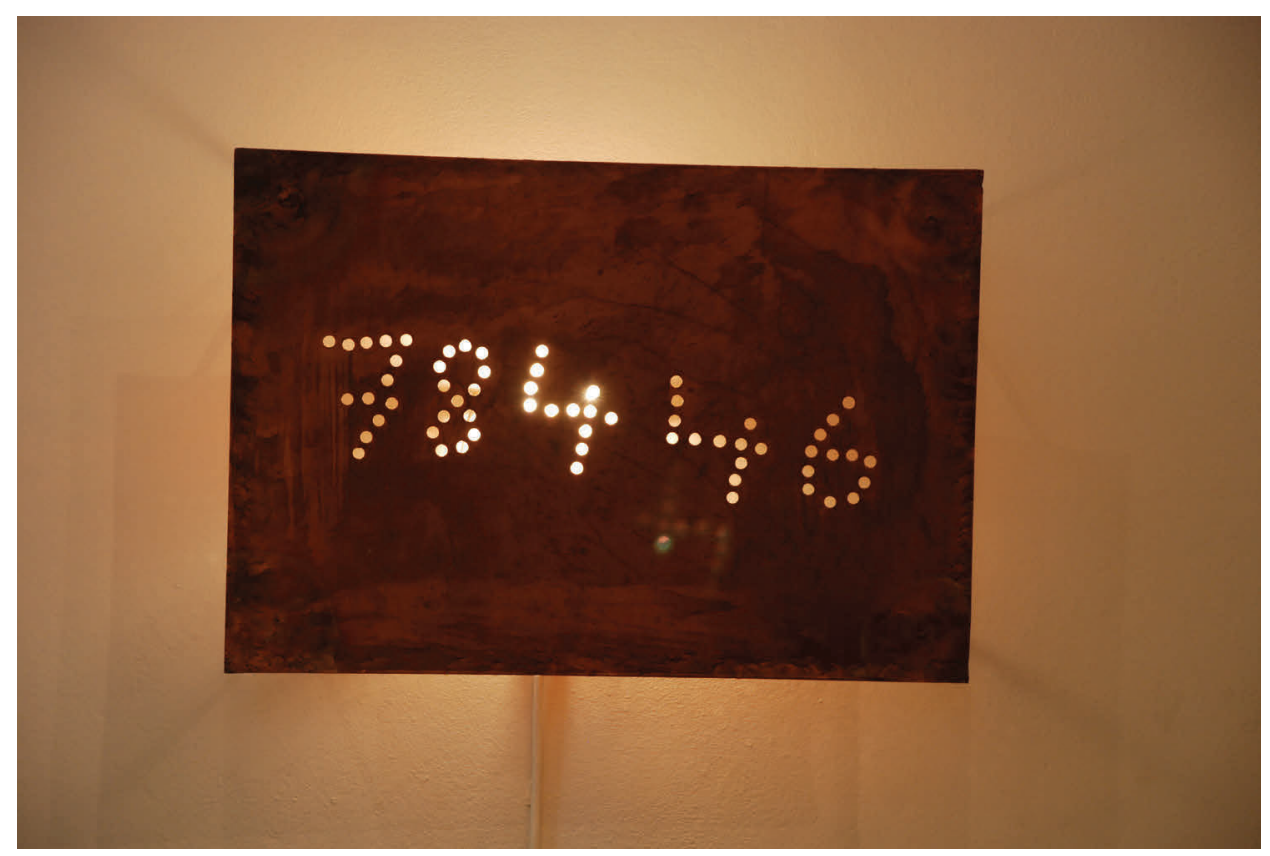

15. Haim Maor, מספר אור / Light Number, 1993

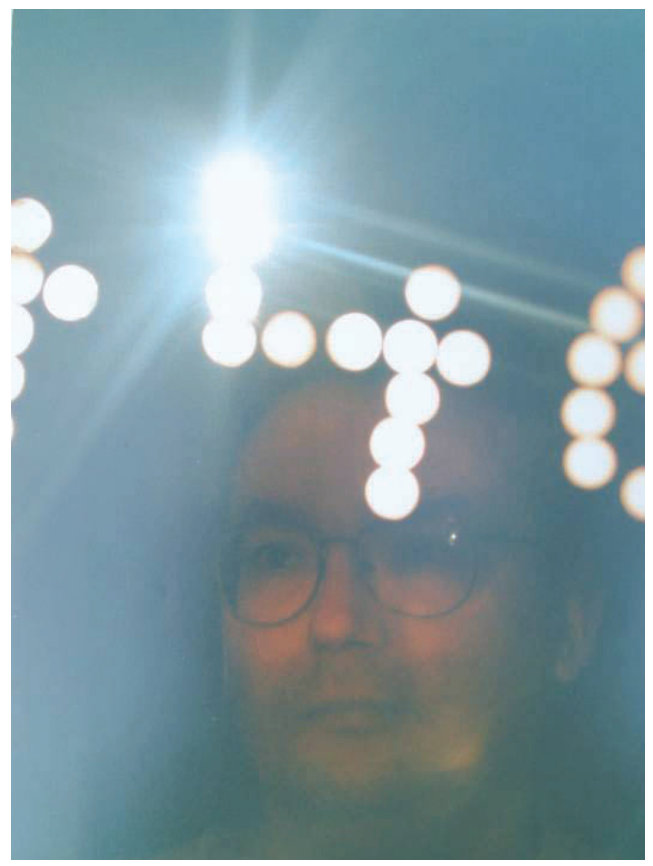




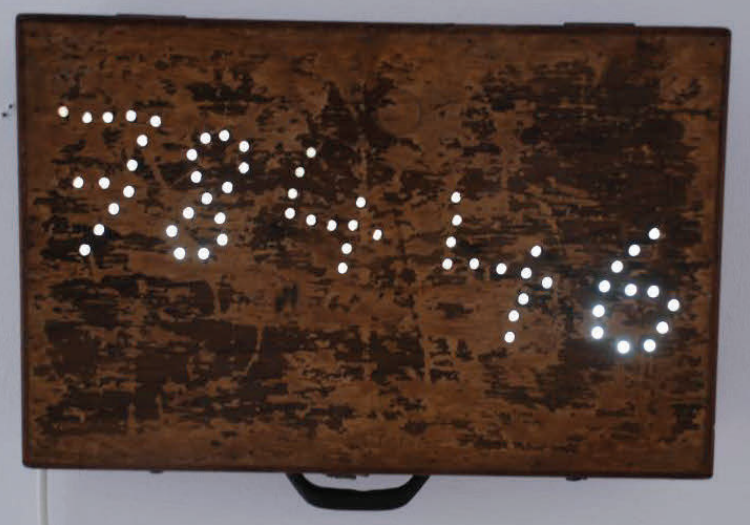

16. Haim Maor, המזוודה של האב / Father's Suitcase, 2008

17. Haim Maor,

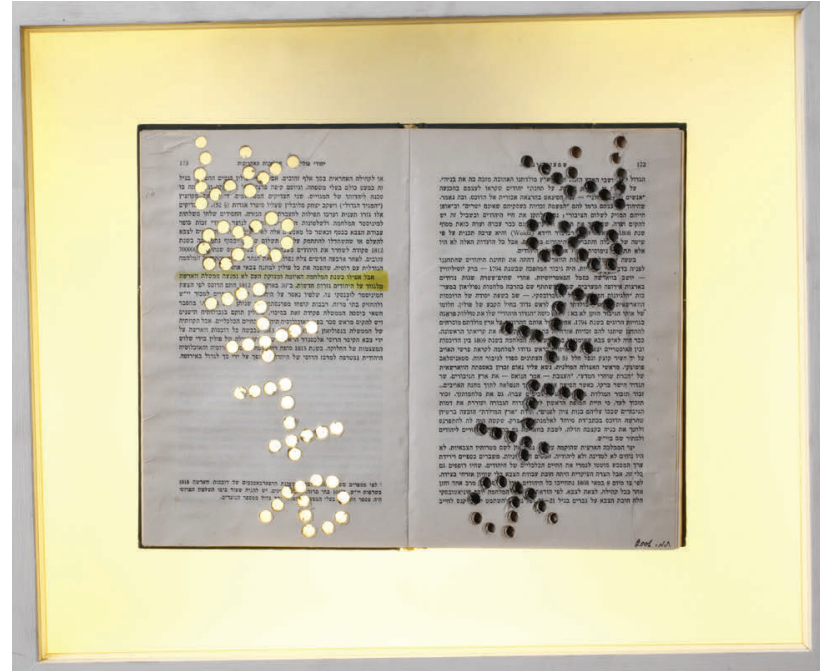

/ המספר של אבא (דובנוב) Father's Number (Dubonow), 2001

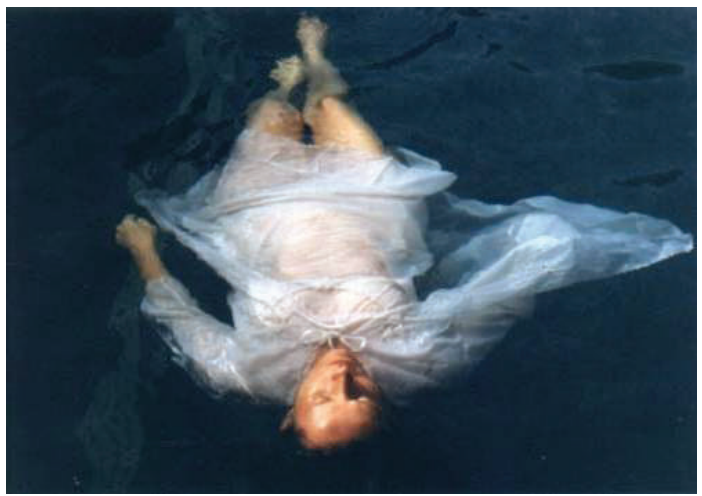

18. Haim Maor, / (רוח אופליה או מלאך נופל (רוח-ים) A Fallen Angel or the Spirit of Ophelia (Vessel of Mer-Sea), 1994 

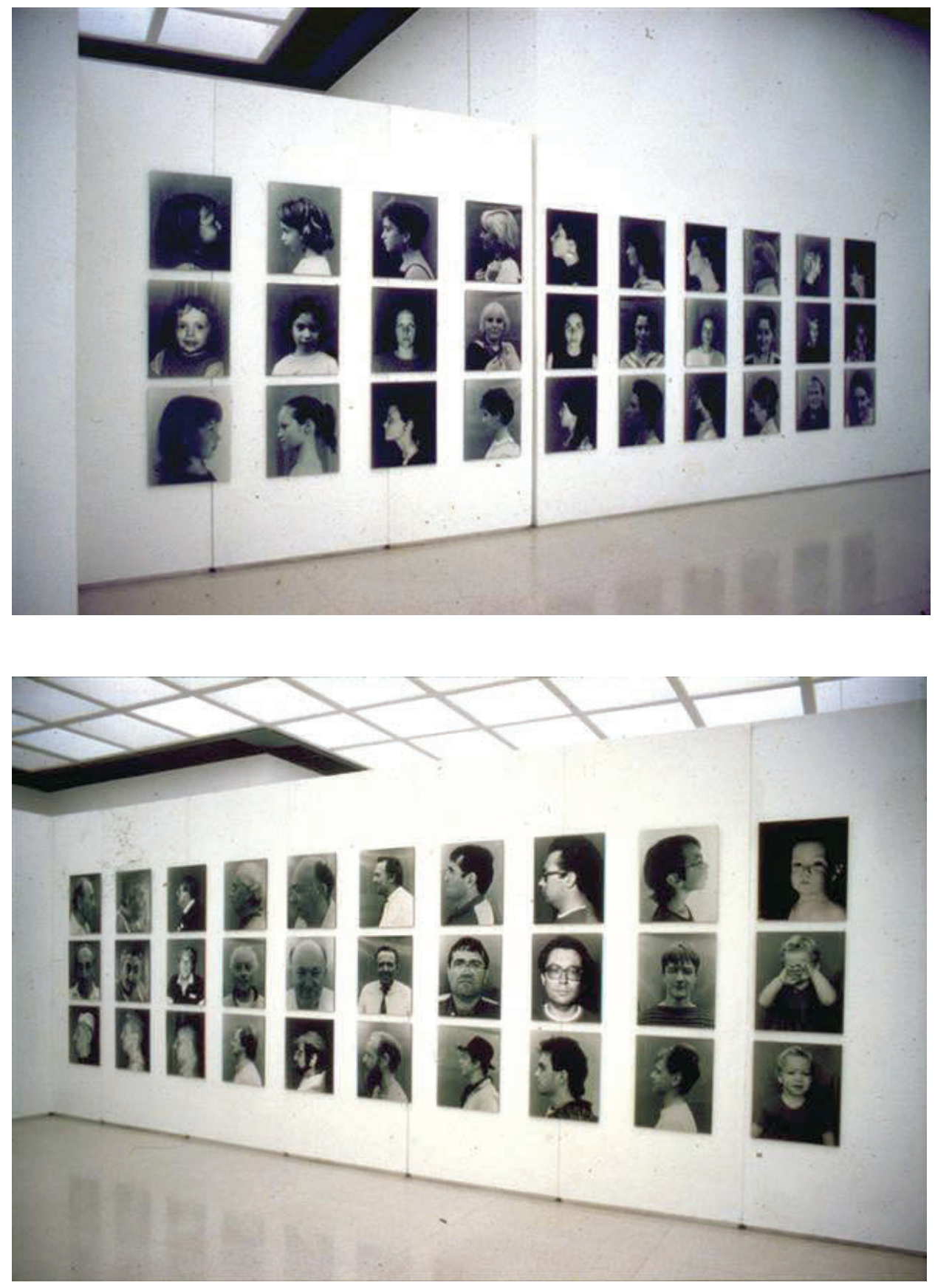

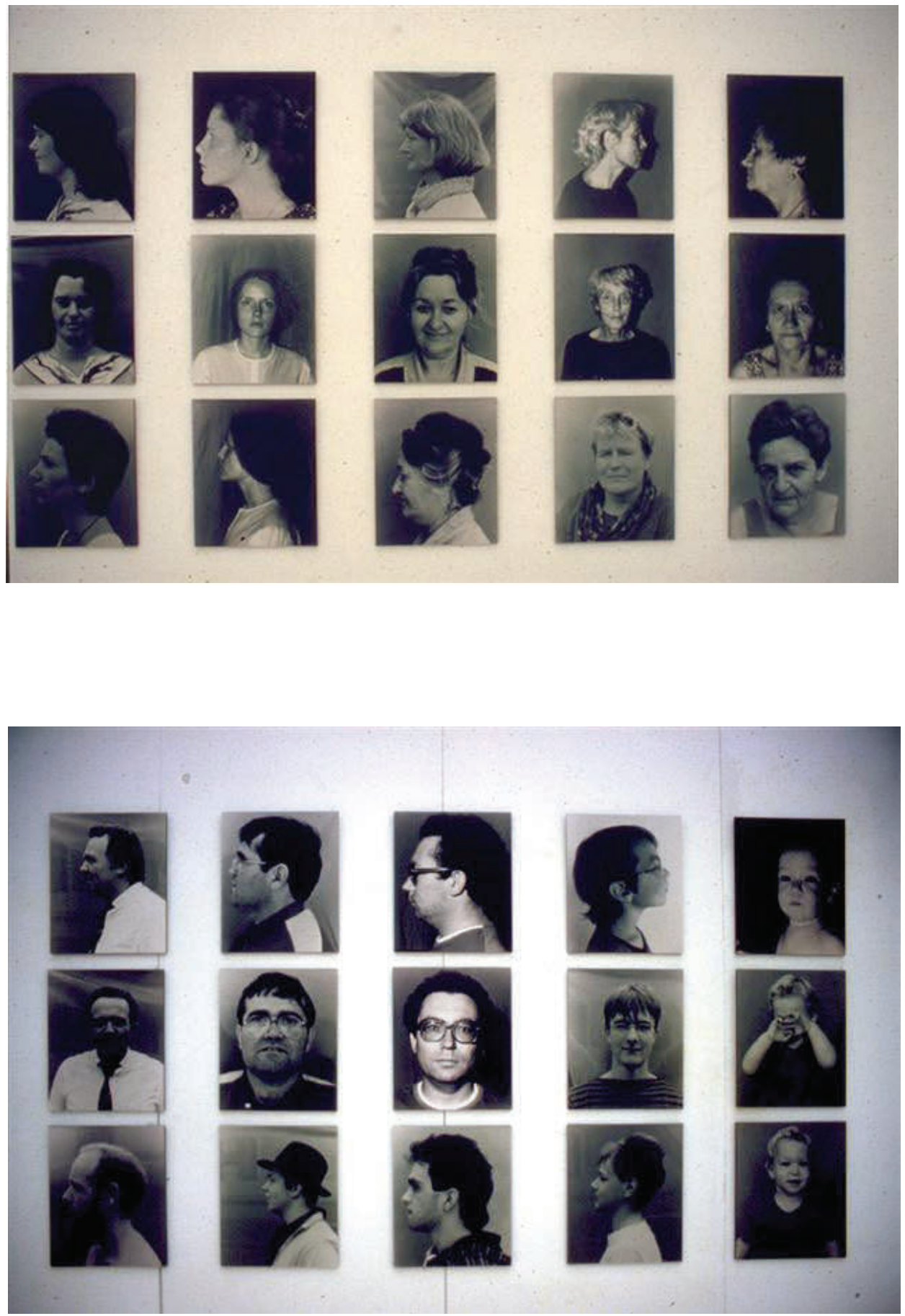

19. Haim Maor, פני הגזע והזיכרון / Faces of Race and Faces of Memory, 1988 

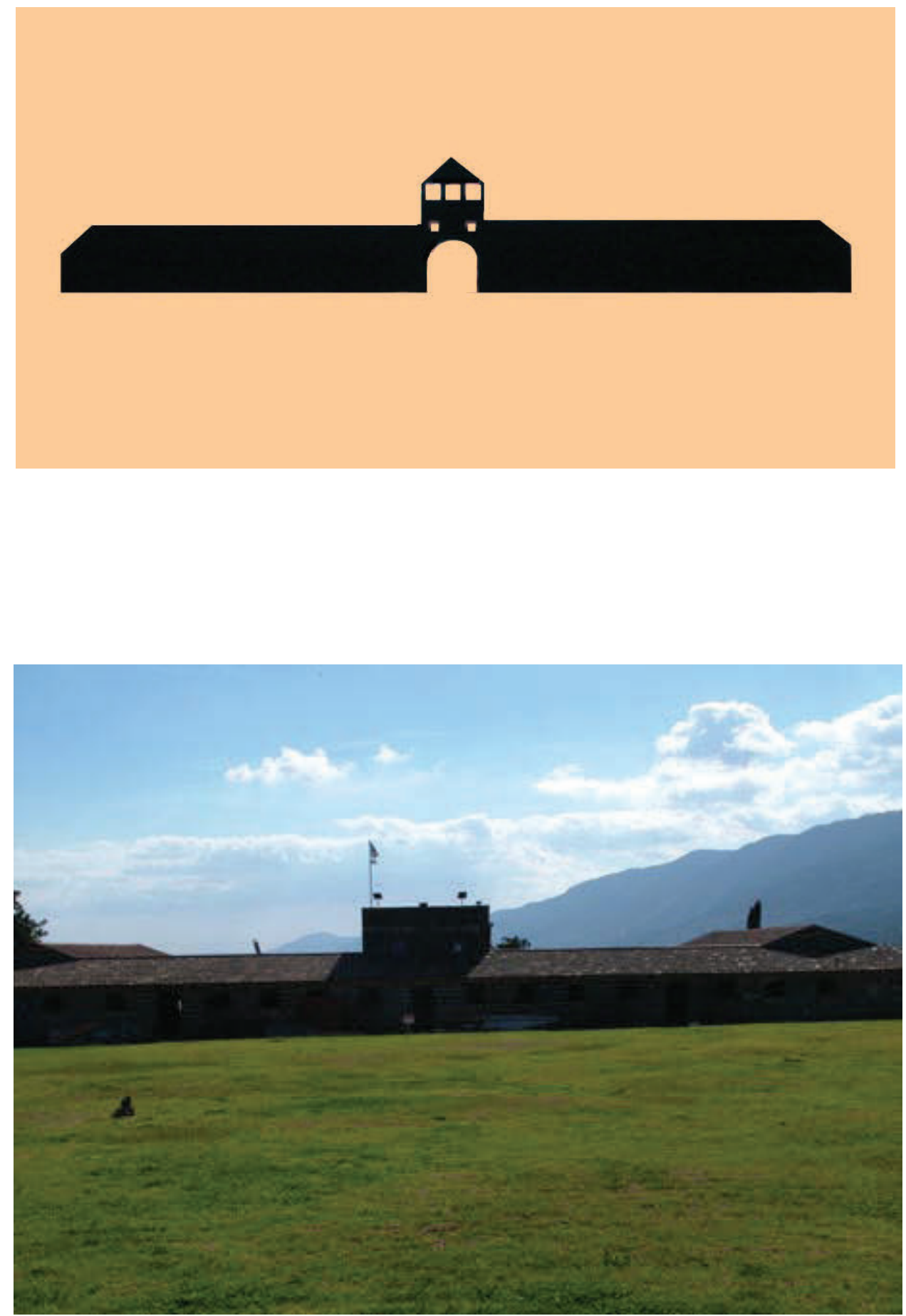

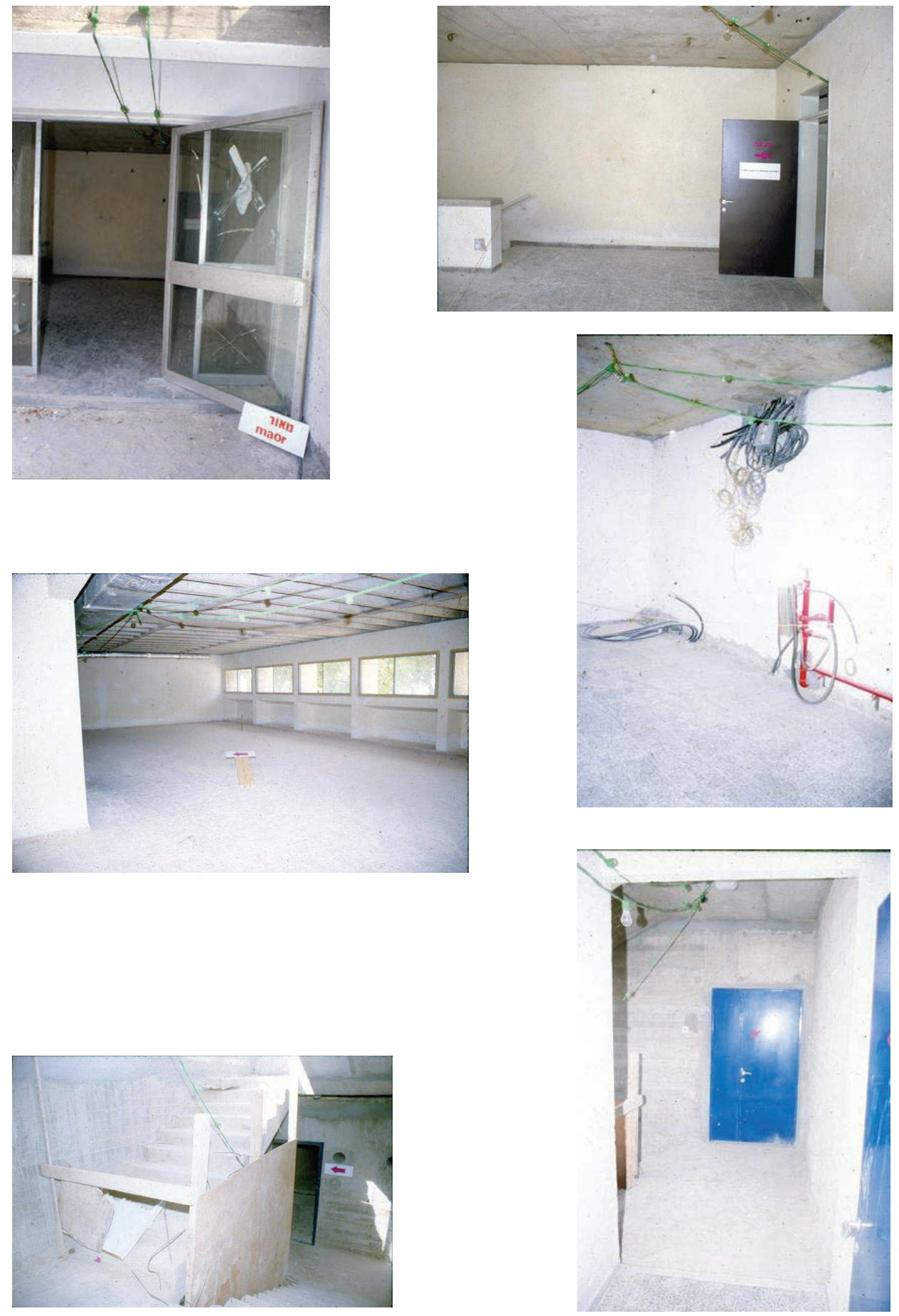

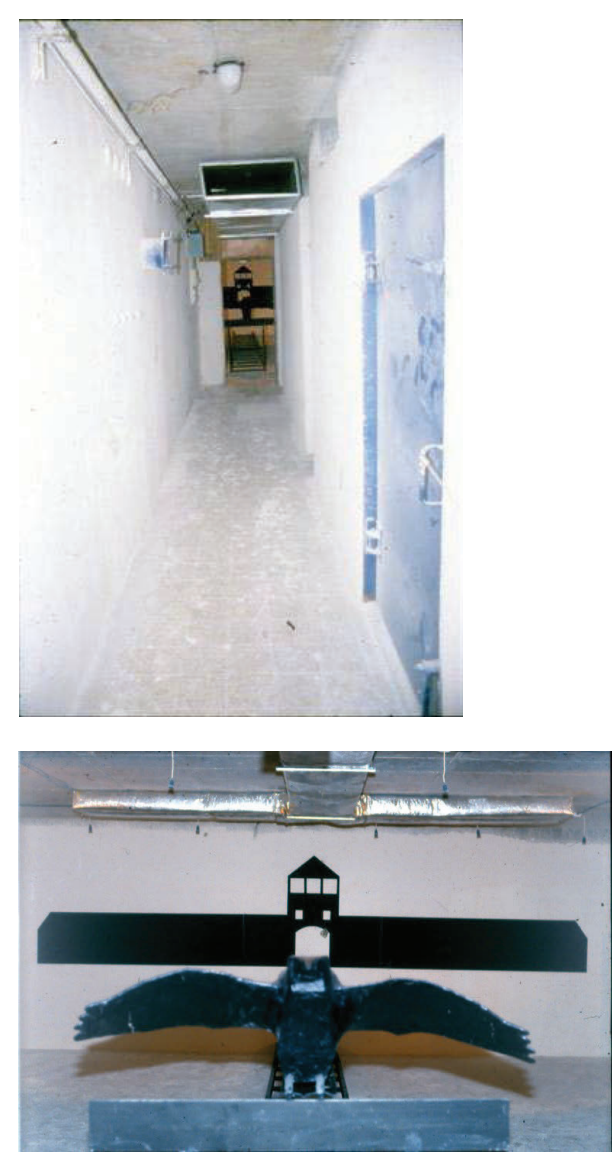
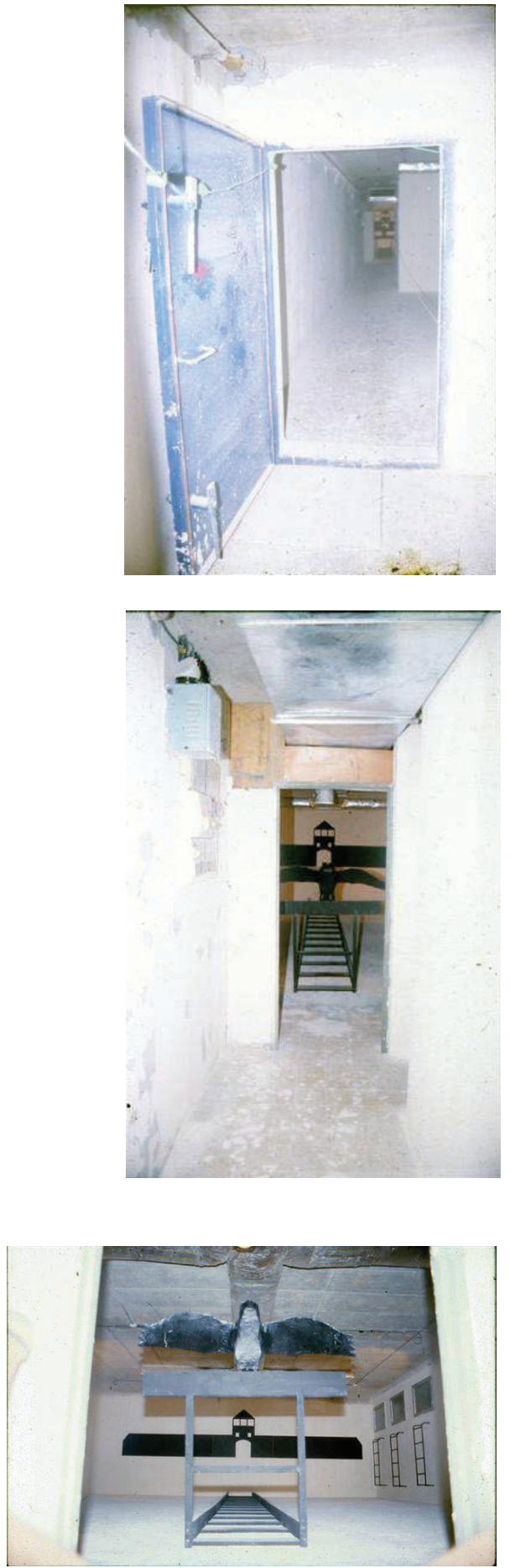

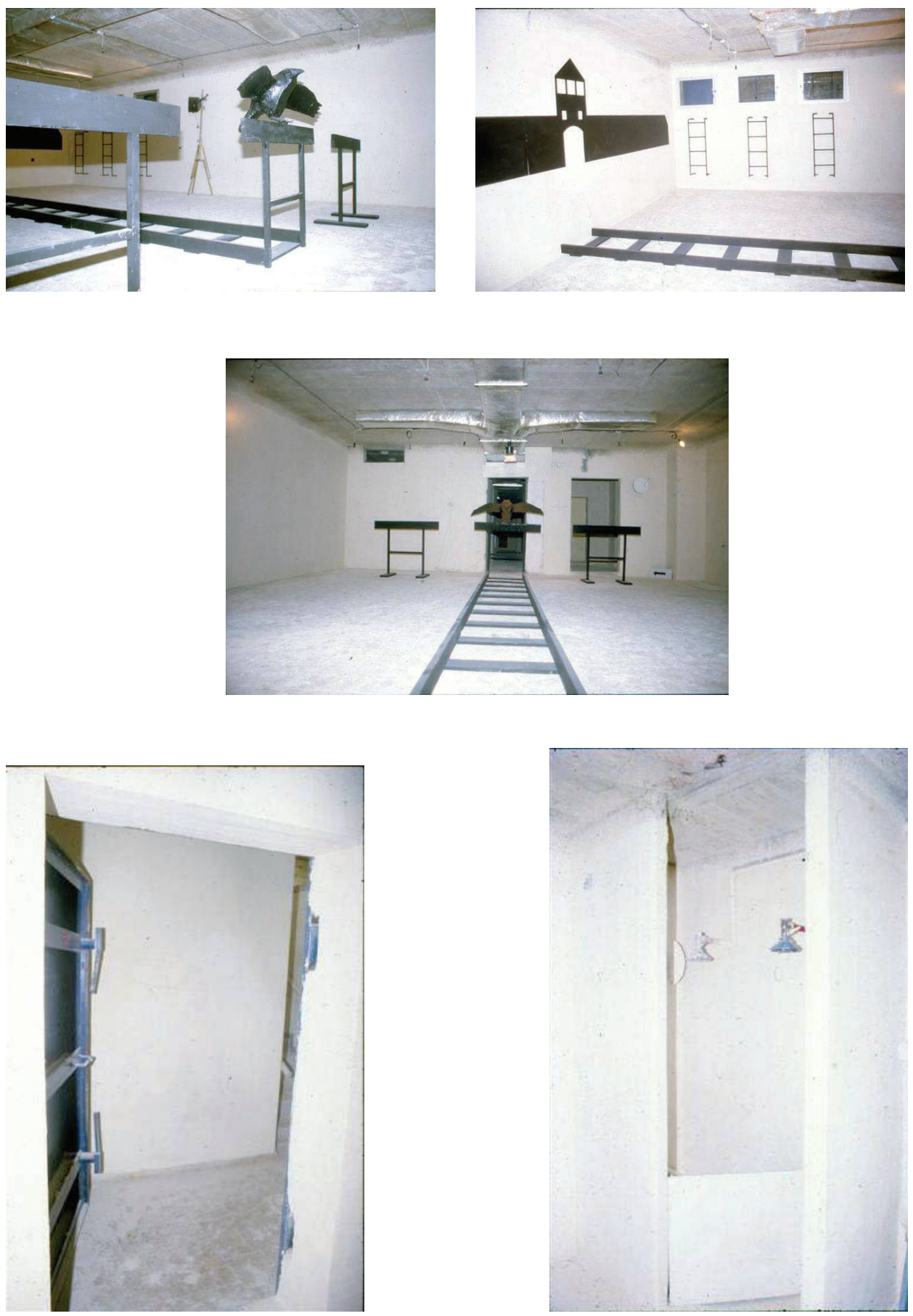

20. Haim Maor, תשדורת מאושוויץ-בירקנאו לתל-חי / A Message from Auschwitz-Birkenau To Tel Hai, 1983 


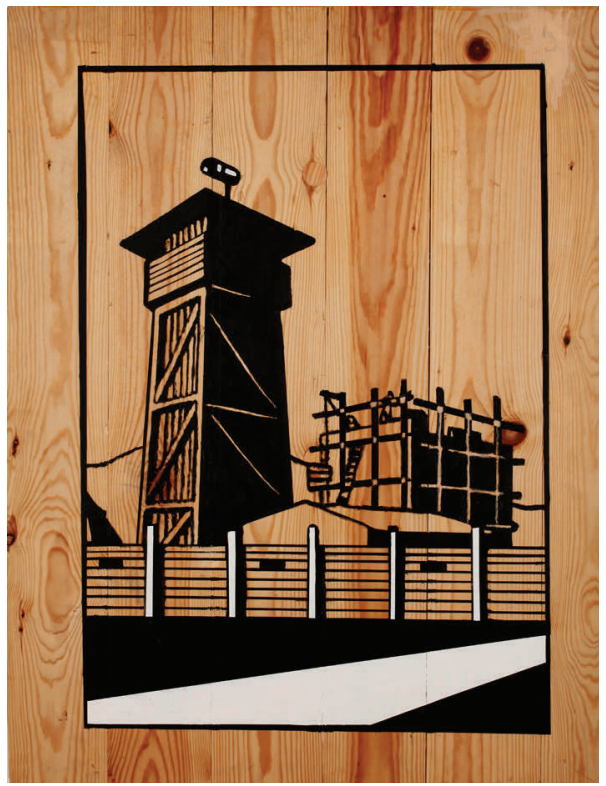

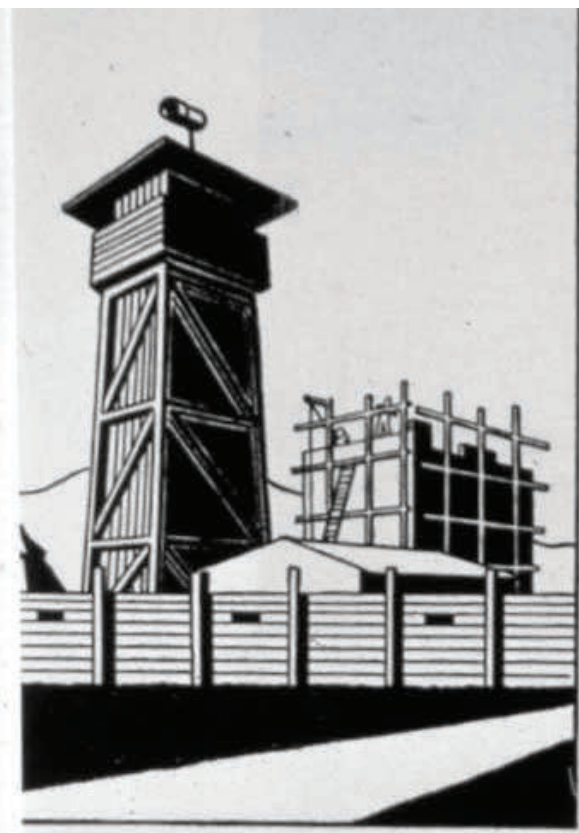

אוטה וליש, איור מתוך

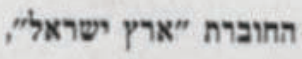
$1937 / 8$
21. Haim Maor, מחנה (על פי אוטה וליש) / Camp (According to Otte Wallish), 2010 


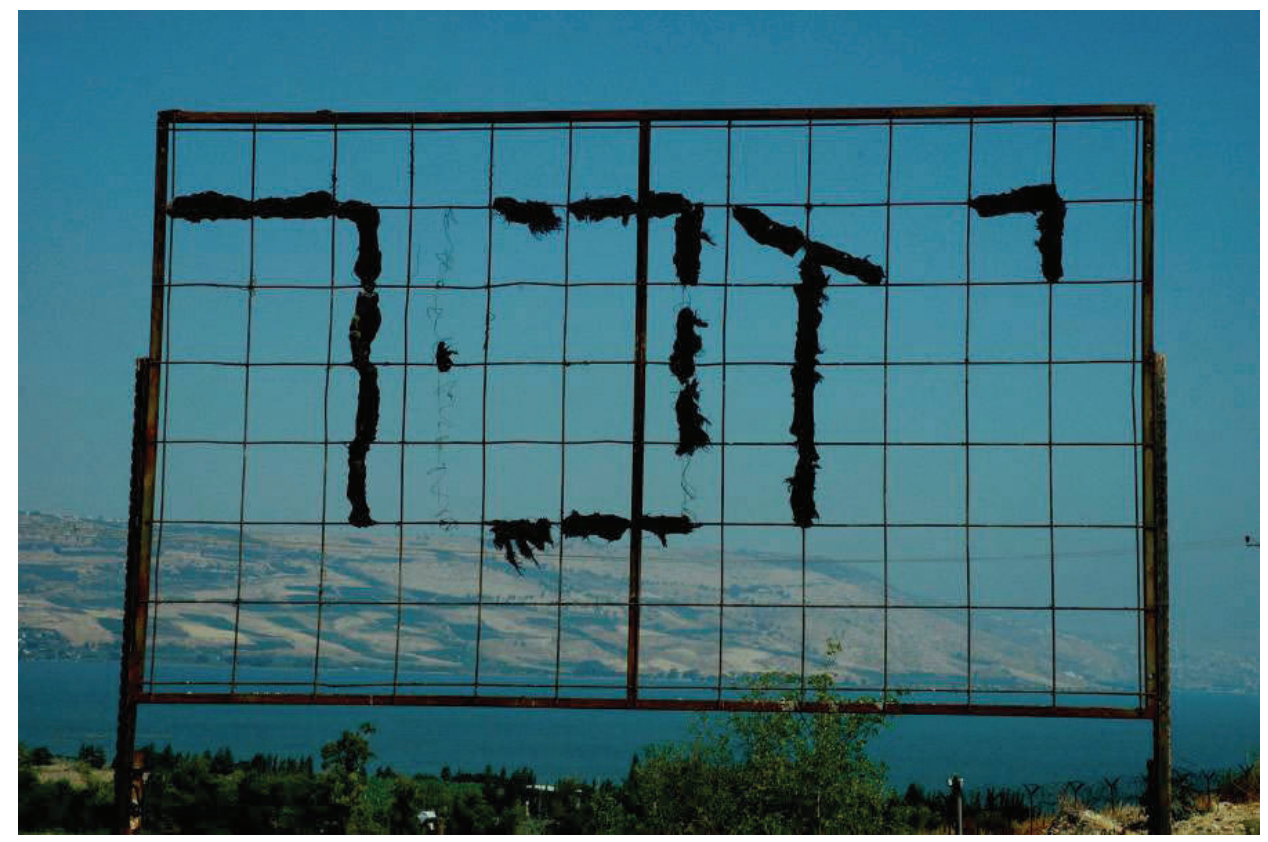

22. Haim Maor, יזכור / Yizkor, 2006 
Rafał Jakubowicz

\author{
Hebrew and Yiddish in Works by Haim Maor, an Israeli Artist of \\ the Second Generation
}

\title{
Summary
}

An Israeli artist of the Second Generation or the postgeneration, Haim Maor uses in his art various means of expression, such as painting, installation, photography, or performance, and creates biographical art. In numerous works, he uses words or texts in Hebrew, Yiddish, English, German, Polish, and Arabic. In this article, the author focuses mainly on these works of art in which Haim Maor - in a way close to conceptualism, postconceptualism, and concrete poetry uses words, especially those in Hebrew and Yiddish. The author refers to the presence of tension in this art between the official language of the young and proud country of Israel (Hebrew) and the language of diaspora, despised by Israeli elites (Yiddish). Works by Maor evoke the Shoah mainly by means of references to familial stories. In the article, the author tackles the motif of memory found in this art, putting it in the context of post-Holocaust art and the notion of postmemory (Marianne Hirsch), and showing the way in which the attitude towards the tragedy of the Shoah transformed in Israel. Maor's art criticises the myths functioning in Israeli society, such as the myth of "beautiful" death. Using not only the research of Israeli Zionist historians (Anita Shapira) and so-called new historians (Shlomo Sand, Tom Segev, Ilan Pappé, Idith Zertal) but also the texts of left-wing publicists and writers (David Grossman, Amos Oz, Ari Shavit), the author attempts to depict the way in which art works through the same problems which historians, writers, and journalists face.

Key words: Haim Maor, Second Generation, new historians, camp prisoner number, postmemory, post-Zionism 